\title{
Nigeria: 2009 Article IV Consultation-Staff Report; Staff Supplement; Public Information Notice on the Executive Board Discussion; Statement by the IMF Staff Representative; and Statement by the Executive Director for Nigeria
}

Under Article IV of the IMF's Articles of Agreement, the IMF holds bilateral discussions with members, usually every year. In context of the 2009 Article IV Consultation discussions with Nigeria, the following documents have been released and are included in this package:

- The staff report, prepared by a staff team of the IMF, following discussions that ended on July 29,2009 , with the officials of Nigeria on economic developments and policies. Based on information available at the time of these discussions, the staff report was completed on September 24, 2009. The views expressed in the staff report are those of the staff team and do not necessarily reflect the views of the Executive Board of the IMF.

- Supplements to the staff report: IMF/World Bank Debt Sustainability Analysis and Informational Annex.

- A Public Information Notice on the Executive Board Discussion (PIN) summarizing the views of the Executive Board as expressed during its October 16, 2009 discussion of the staff report on issues related to the Article VI consultations.

- A Statement by the IMF Staff Representative on Nigeria.

- A statement by the Executive Director for Nigeria.

The documents listed below will be separately released.

Letter of Intent sent to the IMF by the authorities of Nigeria

Memorandum of Economic and Financial Policies by the authorities of

Nigeria

Technical Memorandum of Understanding

The policy of publication of staff reports and other documents allows for the deletion of marketsensitive information.

Copies of this report are available to the public from

International Monetary Fund • Publication Services

$70019^{\text {th }}$ Street, N.W. • Washington, D.C. 20431

Telephone: (202) 623-7430 • Telefax: (202) 623-7201

E-mail: publications@imf.org Internet: http://www.imf.org

\section{International Monetary Fund Washington, D.C.}


INTERNATIONAL MONETARY FUND

NIGERIA

\title{
Staff Report for the 2009 Article IV Consultation
}

\author{
Prepared by the Staff Representatives for the 2009 Consultation with Nigeria
}

Approved by Saul Lizondo and Dhaneshwar Ghura

September 24, 2009

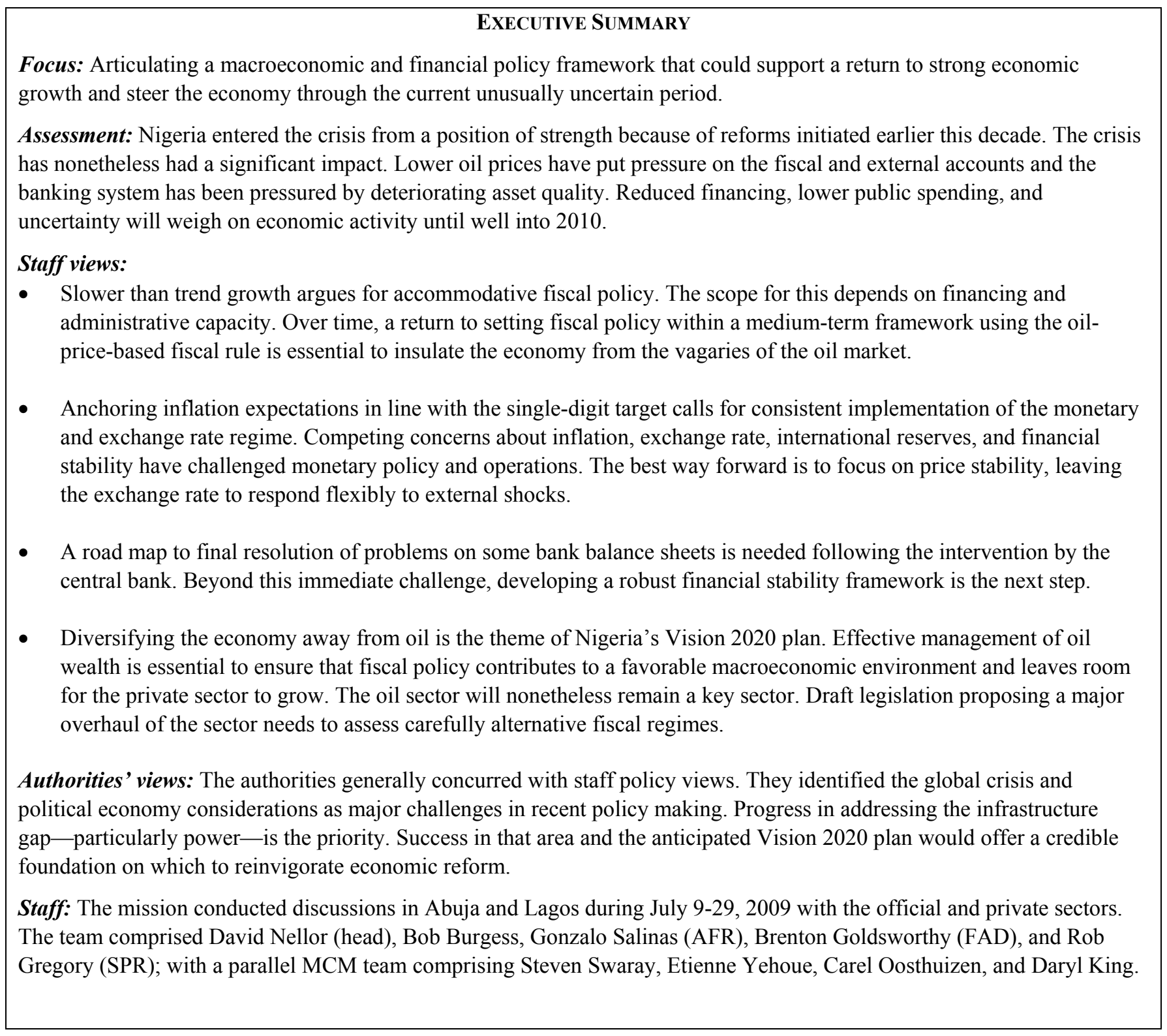


Executive Summary

I. Managing The Global Crisis From A Position of Strength ............................................ 3

A. The Payoff from Earlier Reforms......................................................................... 3

B. Growth Slows and Fiscal and External Balances Move To Deficit ........................ 5

C. Moderate Growth Outlook and Evenly Balanced Risks....................................... 9

II. Setting the Policy Course Following the Global Financial Crisis ................................. 12

A. Fiscal Policy-Options in a Low Growth Environment ...................................... 12

B. Setting Monetary Policy in the Face of Conflicting Goals.................................... 14

C. Financial Stability-Supporting Growth While Managing Risks............................ 18

D. Promoting Economic Growth and Diversification-Vision 2020 ...................... 21

E. Charting a Course for the Oil and Gas Sector ................................................ 24

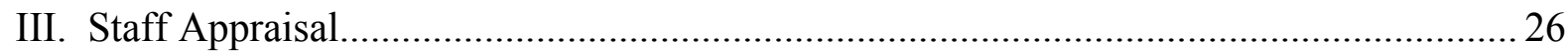

Boxes

1. Main Measures in Response to Crisis ........................................................................... 7

2. Public Financial Management Reforms in State and Local Governments...................... 14

3. The Monetary Policy Regime ............................................................................... 18

4. Experience with Fiscal Rules in Selected Commodity Producing Countries .................. 23

Figures

1. Economic Developments during the Current and Past Oil Cycles................................. 4

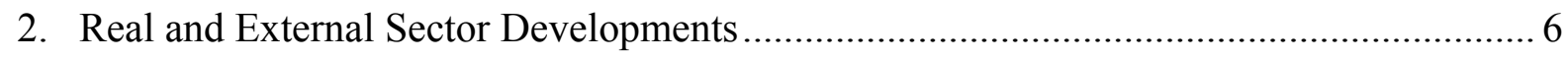

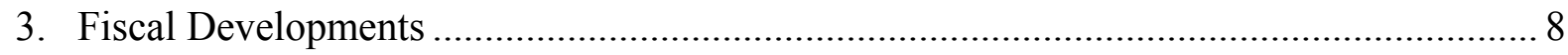

4. Impact of the Global Financial Crisis: Nigeria and Other Oil Producers ....................... 10

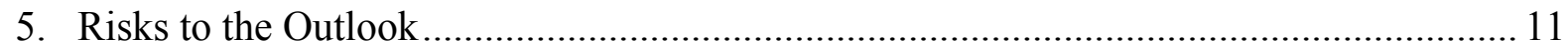

6. Inflation and Monetary Developments............................................................................ 16

7. Average Effective Tax Rates in Selected Oil Producing Countries................................ 25

Tables

1. Selected Economic and Financial Indicators, 2006-14 _.............................................. 28

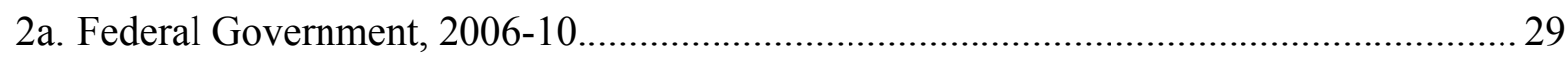

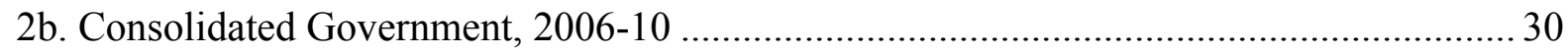

2c. Consolidated and Federal Government, 2006-10 ................................................... 31

3a. Central Bank of Nigeria Analytical Balance Sheet, 2006-10 ..................................... 32

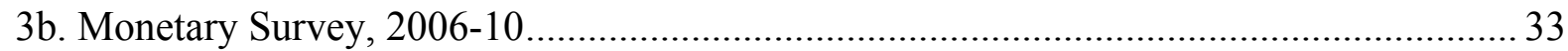

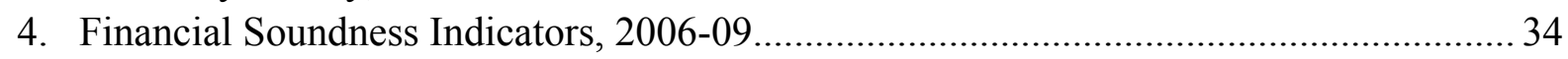

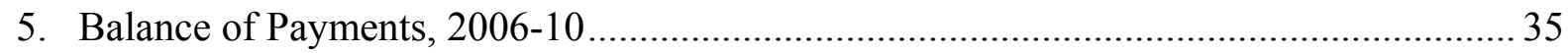

6. Millennium Development Goals — Status at a Glance ................................................ 36

Appendix

Assessment of the Exchange Rate Level of Nigeria ...................................................... 38 


\section{Managing The Global Crisis From a Position of Strength}

Nigeria entered the crisis from a position of strength because of reforms initiated earlier this decade. The crisis has nonetheless had a significant impact on the economy. Lower oil prices have put pressure on the fiscal and external accounts. The banking system has been pressured by deteriorating asset quality.

\section{A. The Payoff From Earlier Reforms}

1. Reforms earlier this decade have left the economy better prepared to deal with the crisis. Central to this success is the oil-price-based fiscal rule. ${ }^{1}$ This rule broke the link between public spending and oil prices and created an oil-savings cushion of $\$ 18$ billion (15 percent of non-oil GDP) as well as foreign reserves that peaked in September 2008 at $\$ 62$ billion (16 months of imports). Similarly, the bank consolidation in 2005-2006, provided the banking sector with a capital buffer against potential losses during an economic downturn.

\section{Increased confidence in economic prospects was reflected in improved growth} and lower inflation. Non-oil growth averaged over 9 percent from 2004 through 2008, as agriculture, telecommunications, construction, and financial services expanded. Although inflation accelerated in 2008 in response to rising global food and fuel prices and the loosening of monetary conditions, it remains below rates prevailing earlier in the decade.

\section{Real incomes have risen significantly, suggesting that poverty is likely to have} fallen. Official estimates of poverty are based on the Nigerian Living Standard Survey (NLSS), which was last conducted in 2004, making it difficult to assess the impact of recent developments. The results of the 2009 NLSS will not be available until 2010. World Bank analysis of the General Household Surveys suggests that real incomes in the formal and informal sectors increased significantly between 1999 and 2006.

4. This positive economic performance underscores the break from past episodes of the oil price cycle. In previous episodes, fiscal policy was highly pro-cyclical because of both mounting oil revenues and debt financing. Periods of high oil prices increased access to debt and pushed up indebtedness. When oil prices turned down the economy went through periods of severe contraction (Figure 1).

\footnotetext{
${ }^{1}$ The oil-price-based fiscal rule, introduced in 2004, is a political agreement between all tiers of government that provides for an allocation of oil revenues based on a budget oil price and volume of production. Oil revenues in excess of the budget price and production are transferred into an "excess crude account" at the central bank in the names of the various governments. As originally designed, the excess crude account is drawn upon only if actual oil receipts fall short of budgeted amounts.
} 
Figure 1. Economic Developments during Current and Past Oil Cycles

An oil price rule led to better management of oil wealth and a stronger fiscal position.

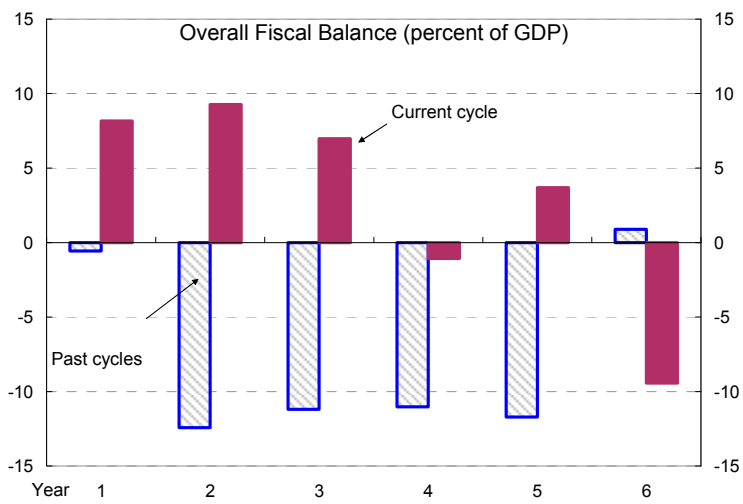

...and, together with debt relief, a reduction of external debt.

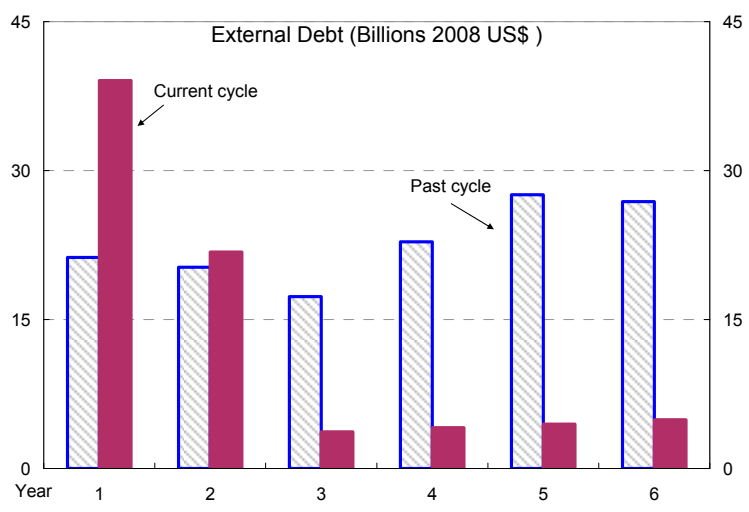

...and lower inflation.

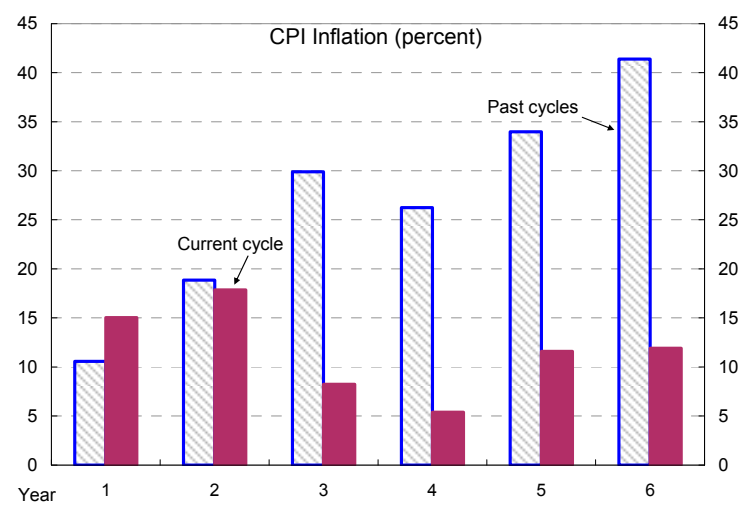

Sources: Nigerian authorities and IMF staff estimates.

\section{Saving part of oil inflows allowed an} accumulation of reserves...

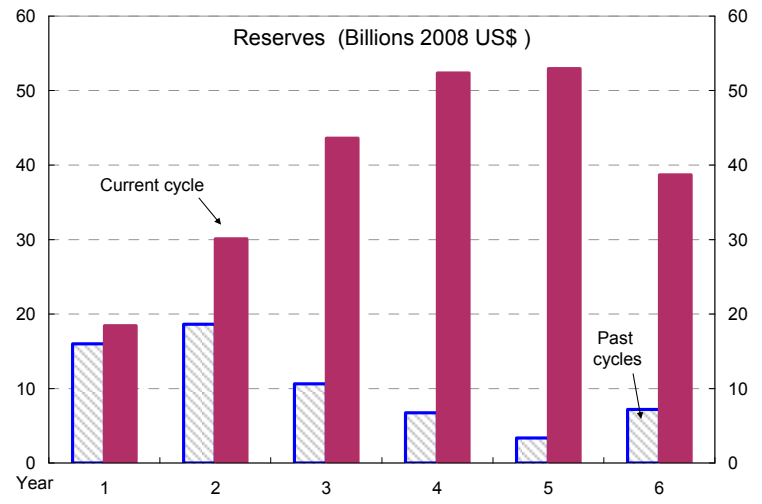

Overall macroeconomic improvement was also evident in stronger growth...

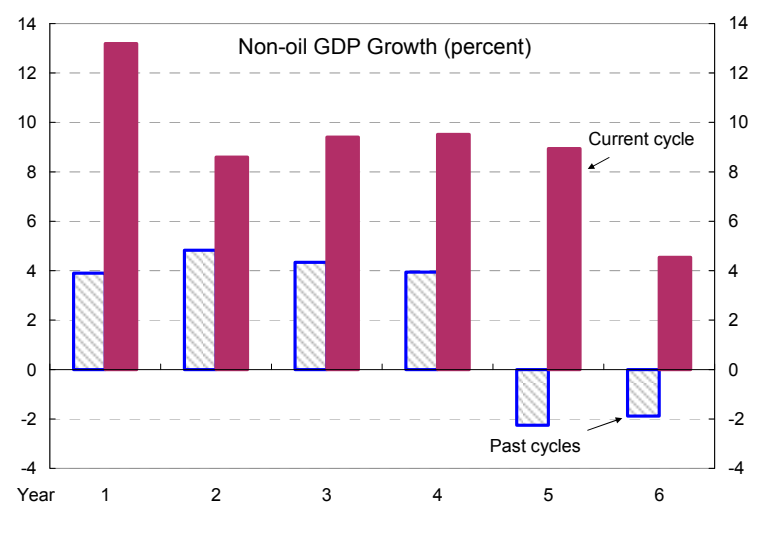

The figures compare economic performance during past and present oil price cycles.

The past oil booms are 1974-79, 1979-84, and 1990-95. The figures show the arithmetic average of the three earlier oil cycles for each variable.

The first year of the episode is shown as year one. In the case of the current oil cycle, year one corresponds to 2004 and year six to staff estimates for 2009. 


\section{B. Growth Slows and Fiscal and External Balances Move to Deficit}

5. The pace of economic activity has slowed in 2009 (Figure 2). A decline in real public sector demand of about 2 percent is restricting activity. Moreover, credit to the private sector has been broadly flat in the first half of 2009. However, with a good harvest in prospect, agricultural production, which grew by over 6 percent in 2008, may again do well. Non-oil sector growth is expected to fall from 9 percent in 2008 to 4.5 percent in 2009. Oil and gas production is constrained by security issues in the Niger Delta and more recently, by OPEC production quotas. Production has averaged about 2 million barrels a day in recent months - 20 percent below its 2005 peak and well below estimated capacity of 2.8 million barrels a day.

6. Inflation is falling albeit after a slow response to declining global food and fuel price inflation. The acceleration in consumer price inflation in 2008 was broad-based. A combination of rising global food and fuel prices, transport bottlenecks caused by local fuel shortages, and the easy monetary conditions prevailing for much of the past year offset the impact of a good harvest. Inflation has moderated from a peak of 15.1 percent in December 2008 to 11.0 percent in August 2009.

7. The balance of payments has weakened because of lower oil revenues and capital outflows. ${ }^{2}$ Net private capital flows turned negative in 2008: the withdrawal of foreign equity investors from the Nigerian market was exacerbated by domestic capital flight as Nigerian banks substantially increased their foreign currency positions. Oil exports, which account for over 90 percent of exports, declined by about half in the first half of 2009. International reserves fell from a peak of \$62 billion in September 2008 to \$43 billion in July 2009.

\section{The naira depreciated in nominal terms but is little changed from pre-crisis}

levels in real terms. Before the crisis, the naira appreciated sharply, reflecting high oil prices and a close link to the strong dollar. With the onset of the crisis, the naira depreciated against the dollar by 25 percent from December 2008 to January 2009 before the authorities introduced temporary measures that fixed the rate at the prevailing dollar exchange rate (Box 1). A sizeable spread between the parallel market and official rates emerged, peaking at about 25 percent in early May 2009 before falling to 7 percent by July after temporary exchange restrictions were eased. ${ }^{3}$ Through the crisis period, the naira depreciated by 21 percent in real effective terms. Nonetheless, the real effective rate of the naira in June

\footnotetext{
${ }^{2}$ This report uses a balance of payments data series that differs from that used in previous staff reports. The Statistical Issues Appendix details these changes.

${ }^{3}$ Nigeria is not an Article VIII member. As reported at the time of the last Article IV consultation, multiple prices are a technical characteristic of the central bank's Dutch auction system and give rise to a multiple currency practice (MCP). Staff does not recommend approval of this MCP.
} 
2009 is only 3 percent below year-ago levels. Staff analysis, while subject to considerable uncertainty, suggests that the real exchange rate is consistent with external stability as of mid-2009 (Appendix I).

Figure 2: Real and External Sector Developments

Oil production remains constrained and gas supplies have also been disrupted

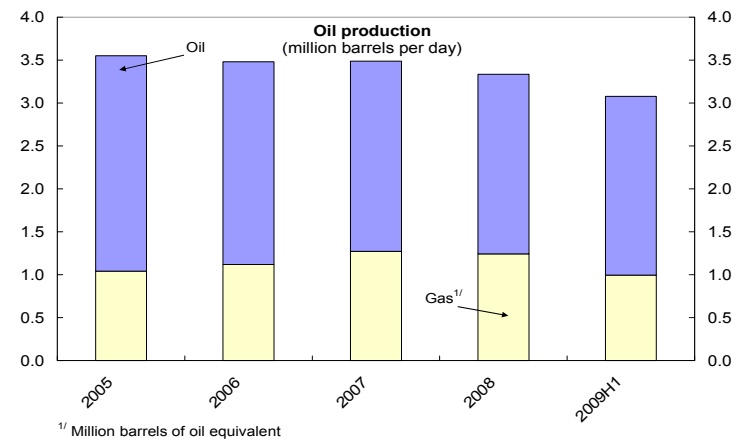

Lower oil exports and net capital inflows put pressure on the external accounts

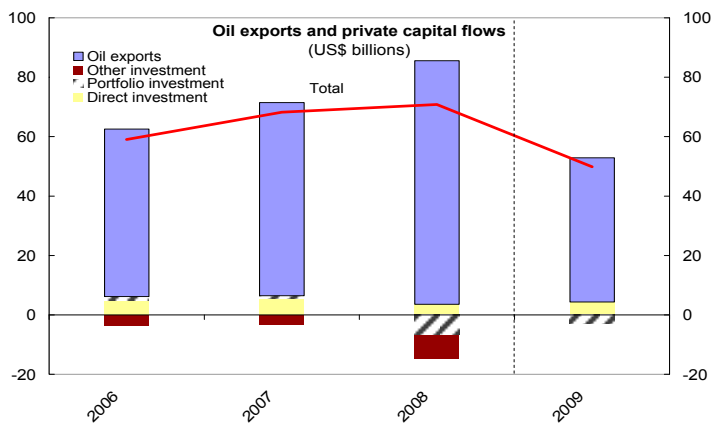

...as the government defended the naira, prompting a decline in foreign reserves...

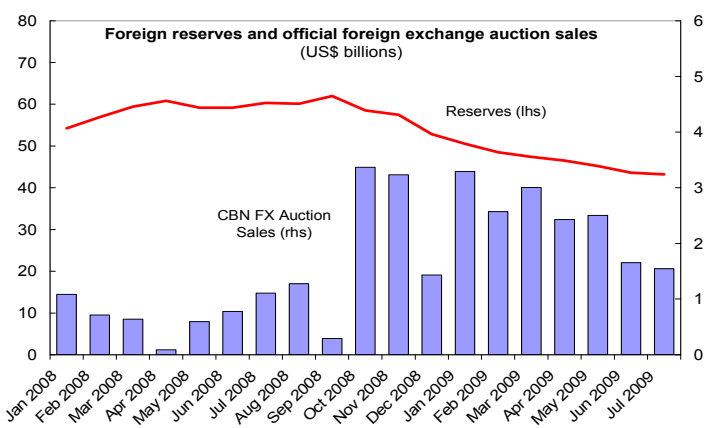

The non-oil sector continues to drive growth but is expected to slow

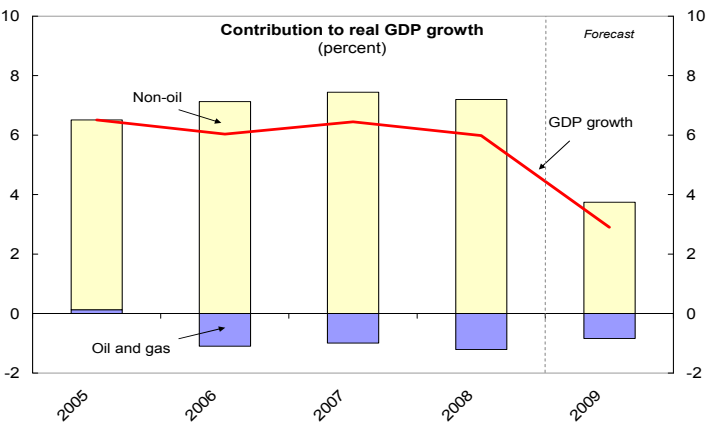

The real effective exchange rate responded only with a lag to the shock to oil prices...

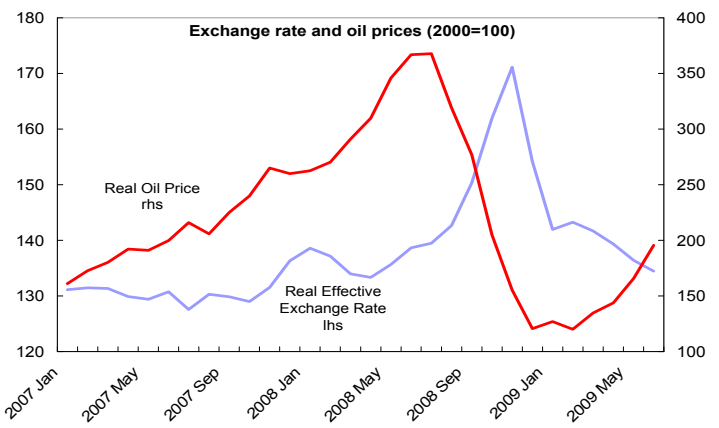

... and recourse to administrative measures, causing the parallel market premium to spike

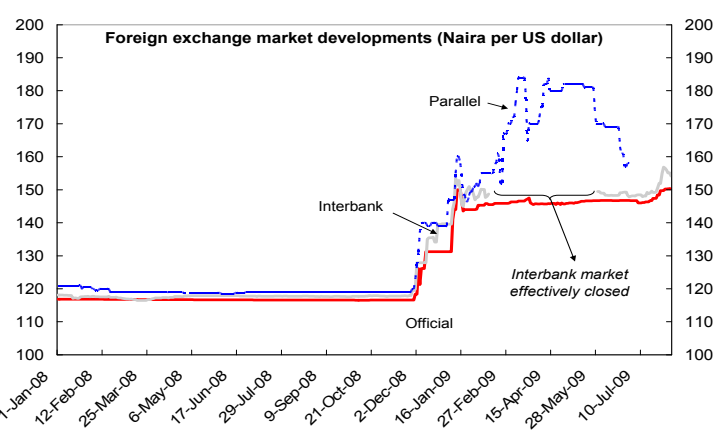

Sources: Nigerian authorities and IMF staff estimates. 


\section{Box 1. Main Measures in Response to the Crisis}

Crisis Measures (Sep. 2008-Mar. 2009)

Current Policy (August 2009)

Domestic money and credit markets

- Policy lending rates reduced in two stages from $10 \frac{1}{4}$ to 8 percent

- Cash reserve requirement reduced from 4 to 1 percent

- Liquidity ratio reduced from 40 to 25 percent

- Discount window facility expanded: lending extended from overnight to up to 360 days; range of eligible collateral increased

- Regulatory forbearance on loans for share purchases

- Ceilings on deposit and lending rates introduced
- Financial sector surveillance increased, resident bank examiners introduced

- Special examinations of bank balance sheets. Banks required to bring off-balance sheet capital market exposure on to their balance sheets and fully provision for non-performing assets.

- Expanded discount window closed

- Ceilings on deposits and lending rates eliminated

- Interbank transactions guaranteed until March 2010

- On-lending of proceeds from repo transactions permitted

- Monetary policy rate redefined as the mid-point between the central bank lending rate of 8 percent and a deposit rate of 4 percent

\section{Foreign exchange market}

- Retail Dutch Auction System (RDAS) replaces wholesale version (WDAS).

- Oil companies and government agencies required to sell foreign exchange to the central bank rather than interbank markets

- Bank net foreign exchange open position limits reduced in stages from 20 to 1 percent

- Banks required to transact foreign exchange within +/- 1 percent of the official (RDAS) rate

- Official rate managed within a band of $+/-3$ percent around central rate of 145.5

\section{Fiscal policy}

- Budget oil price assumption reduced to $\$ 45$ from $\$ 62$ a barrel

- Plans for \$500 million Eurobond issue shelved
- WDAS resumed

- Requirements to sell foreign exchange to the central bank eliminated.

- Bank net open limits increased to 5 percent

- Banks free to determine rate at which they transact foreign exchange.

- Central bank established quarterly program of foreign exchange sales

9. Driven by falling oil revenues, the fiscal accounts moved from surplus to deficit (Figure 3). The overall balance of the consolidated government is projected to swing from a surplus of 3.7 percent of GDP in 2008 to a deficit of 9 percent of GDP in 2009. This turnaround is entirely due to the drop in oil revenue: the non-oil deficit is expected to narrow by almost 4 percentage points to 27 percent of non-oil GDP. A modest increase in spending 
by the federal government is more than offset by significant spending compression at state and local government levels where access to borrowing is limited. ${ }^{4}$

Figure 3: Fiscal Developments

Prudent fiscal policy led to oil savings

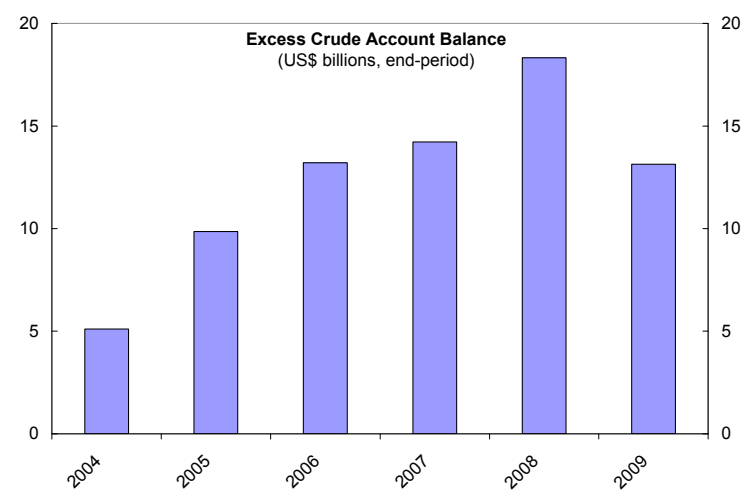

...has enabled the partial accommodation of a large fall in oil revenues...

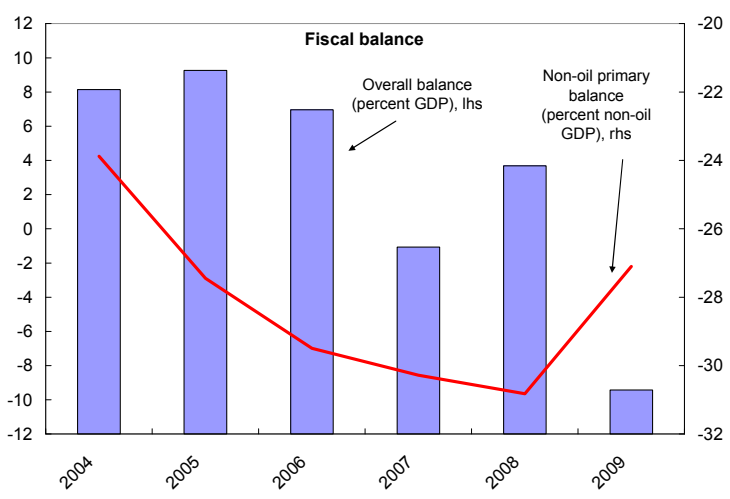

....and moderate public debt

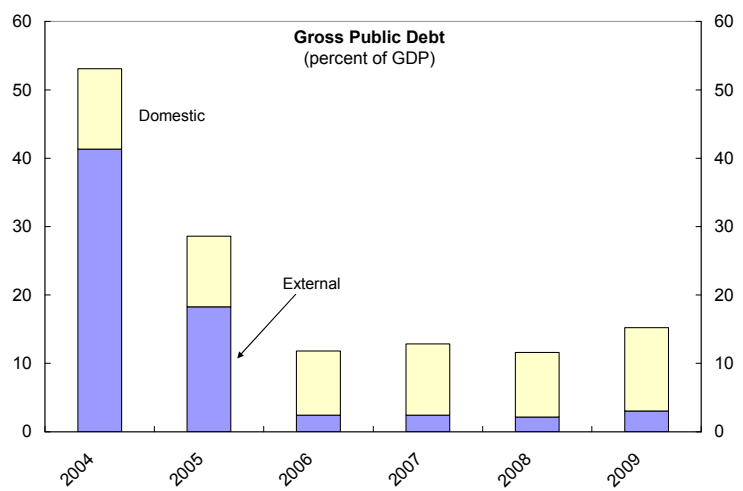

....and reduced the need for real spending compression

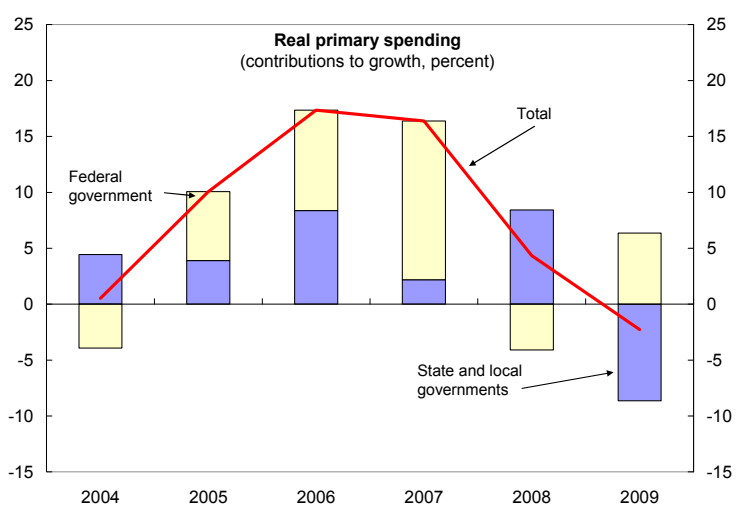

Sources: Nigerian authorities and IMF staff estimates.

\section{The growth rate of monetary and credit aggregates has slowed sharply}

triggered by the economic slowdown and central bank intervention in some banks. The crisis-induced growth slowdown, falls in equity market indices, a depreciated naira, lower oil prices, and a period of very rapid credit growth raised questions about bank asset quality. Signs of stress in the banking system became evident in the interbank market where activity diminished as the crisis developed. Following special examinations, the central bank

\footnotetext{
${ }^{4}$ The debt sustainability analysis concludes that Nigeria's debt outlook remains robust. Since the last Article IV, the authorities have extended until 2010 a memorandum of understanding with the Chinese Government for a $\$ 500 \mathrm{~m}$ infrastructure loan that, if taken forward, would be on concessional terms. In the event that such a loan is contracted, it would not modify the assessment of debt sustainability.
} 
intervened in some banks by replacing management and injecting funds. It was learned that governance in some banks had been weak and legal actions are pending. These developments have contributed to a tightening of lending (see section II C).

\section{The crisis has affected Nigeria somewhat less than many other oil producers}

(Figure 4). The decline in revenues has been less than in some other countries, and the compression in real public expenditure has been more modest. Non-oil growth, though falling, is set to hold up better than in many other countries. However, Nigeria has seen a greater reduction in international reserves than many other oil producers because it sought to contain the decline in the nominal value of the naira.

\section{Moderate Growth Outlook and Evenly Balanced Risks}

12. Growth is expected to remain slower than in recent years. Reduced financing (both foreign and domestic), constraints on public spending, and uncertainty about global and domestic prospects, will weigh on consumption and investment until well into 2010. Non-oil growth is projected to slow from 9 percent in 2008 to 4.5 percent in 2009, and to pick up gradually thereafter as confidence in the banking system is restored and oil prices recover. The current account surplus, after falling by 13 percentage points of GDP in 2009, should strengthen as oil prices recover and production picks up.

\begin{tabular}{|c|c|c|c|c|}
\hline \multicolumn{5}{|c|}{$\begin{array}{l}\text { Nigeria: Economic Outlook } \\
\text { (Percent, unless otherwise stated) }\end{array}$} \\
\hline & 2007 & 2008 & 2009 & 2010 \\
\hline & $\overline{\text { Act. }}$ & $\overline{\text { Act. }}$ & Est. & Proj. \\
\hline Real GDP growth & 6.4 & 6.0 & 2.9 & 5.0 \\
\hline Non-oil GDP growth & 9.5 & 9.0 & 4.5 & 4.8 \\
\hline Oil production (millions barrels a day) & 2.2 & 2.1 & 2.1 & 2.1 \\
\hline Consumer price inflation, end of period & 6.6 & 15.1 & 9.1 & 8.5 \\
\hline Overall fiscal balance (percent of GDP) & -1.1 & 3.7 & -9.0 & -0.1 \\
\hline Non-oil primary fiscal balance (percent of non-oil GDP) & -30.3 & -30.8 & -27.0 & -27.0 \\
\hline Current account balance (percent of GDP) & 18.8 & 20.4 & 6.9 & 13.8 \\
\hline Gross international reserves (US\$ billions) & 51.3 & 53.0 & 41.6 & 44.1 \\
\hline Oil price (US\$ a barrel) & 71.1 & 97.0 & 61.5 & 76.5 \\
\hline
\end{tabular}

Sources: Nigerian authorities and IMF staff

13. The medium term growth outlook depends on the success of efforts to realize the potential of oil and gas reserves and to address the infrastructure gap. Apart from security related issues holding oil and gas below potential, the policy framework for the oil and gas sector will be critical (see Section II E). The rapid non-oil growth of recent years was sustained by increases in agricultural acreage and the take off in sectors such as telecommunications. Ongoing reliance on these sources of growth is not likely to be sustainable. The baseline growth rate is assumed to be about $6 \frac{1}{2}$ percent over the medium term consistent with preparatory work for the national plan that projects a growth rate of 6.9 percent in $2010-14$. 
Figure 4: Impact of the Global Financial Crisis: Nigeria and Other Oil Producers

The global crisis prompted further outflows from a stock market that was already in retreat

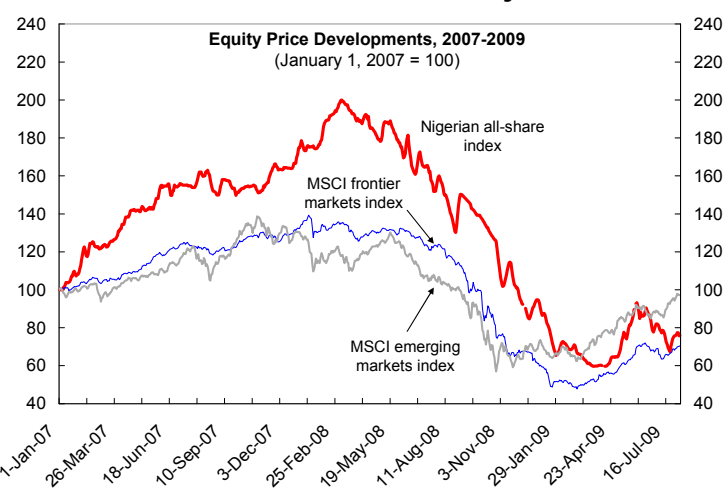

Other commodity producers were quicker to allow depreciation than Nigeria

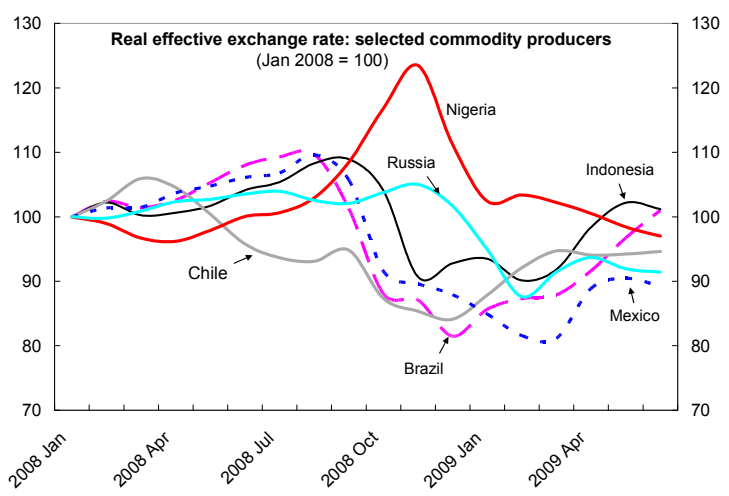

..but spending compression is set to be comparatively small...
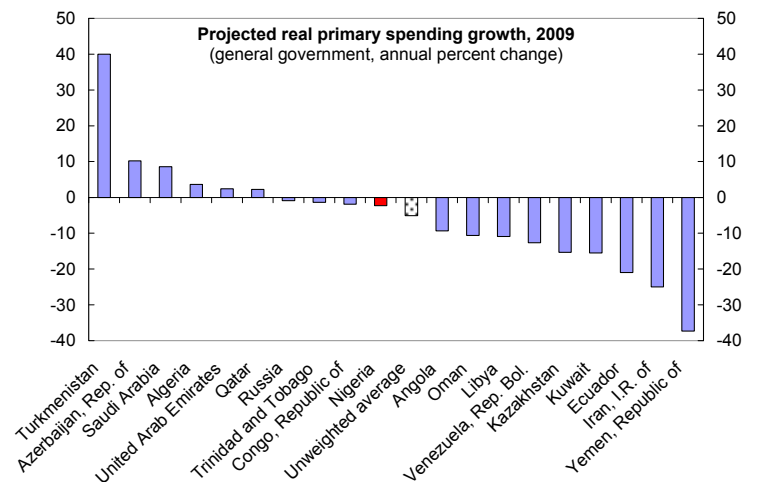

Foreign reserves have fallen by more than the average for oil producers

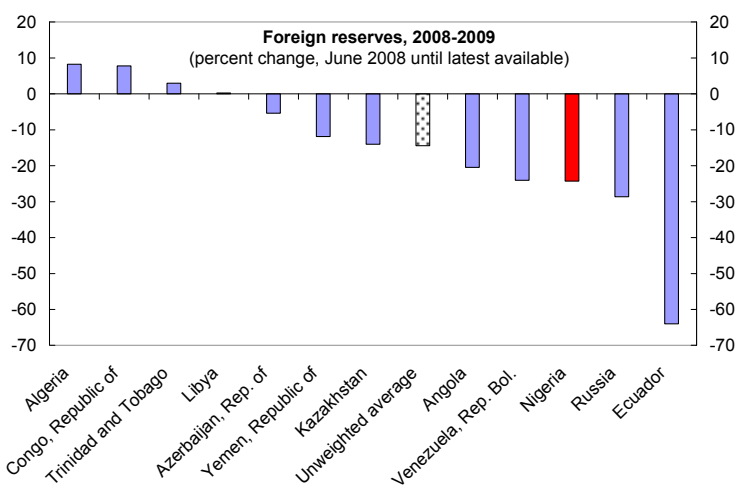

As in other oil producers, government revenues are projected to fall sharply in 2009...

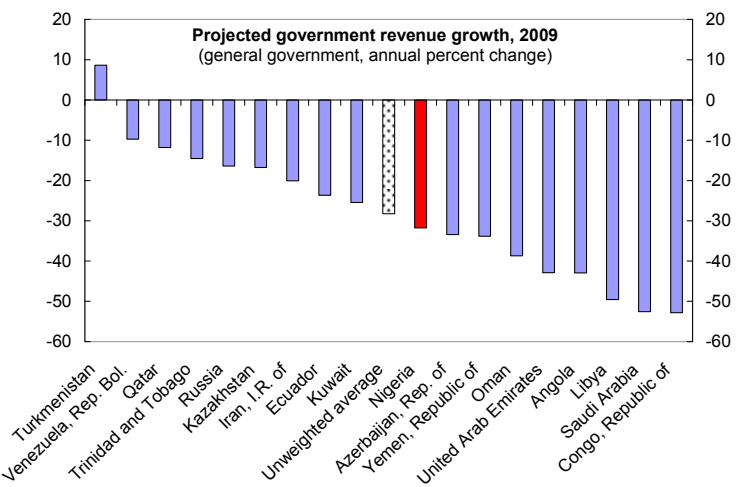

...which should limit the slowdown in non-oil growth.

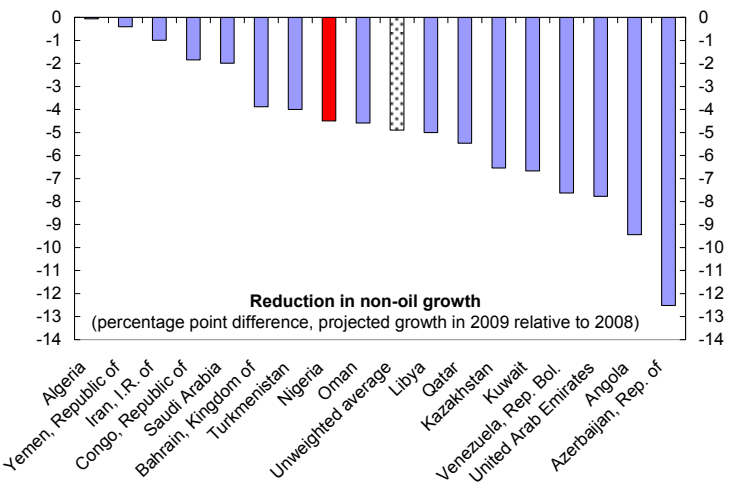

Sources: IMF staff estimates, based on definitions and projections in the April 2009 World Economic Outlook. 


\section{Risks to the immediate outlook are substantial and evenly balanced.}

Uncertainty about the depth and duration of the global recession, and the associated outlook for oil prices, implies a range of possible outcomes on either side of the baseline projection. Wide ranging market expectations of oil prices have profound implications for the possible outcome for Nigeria (Figure 5). The baseline could also change depending on how quickly domestic issues, concerning hydrocarbon production and the banking sector, are resolved

\section{Figure 5. Risks to the Outlook}
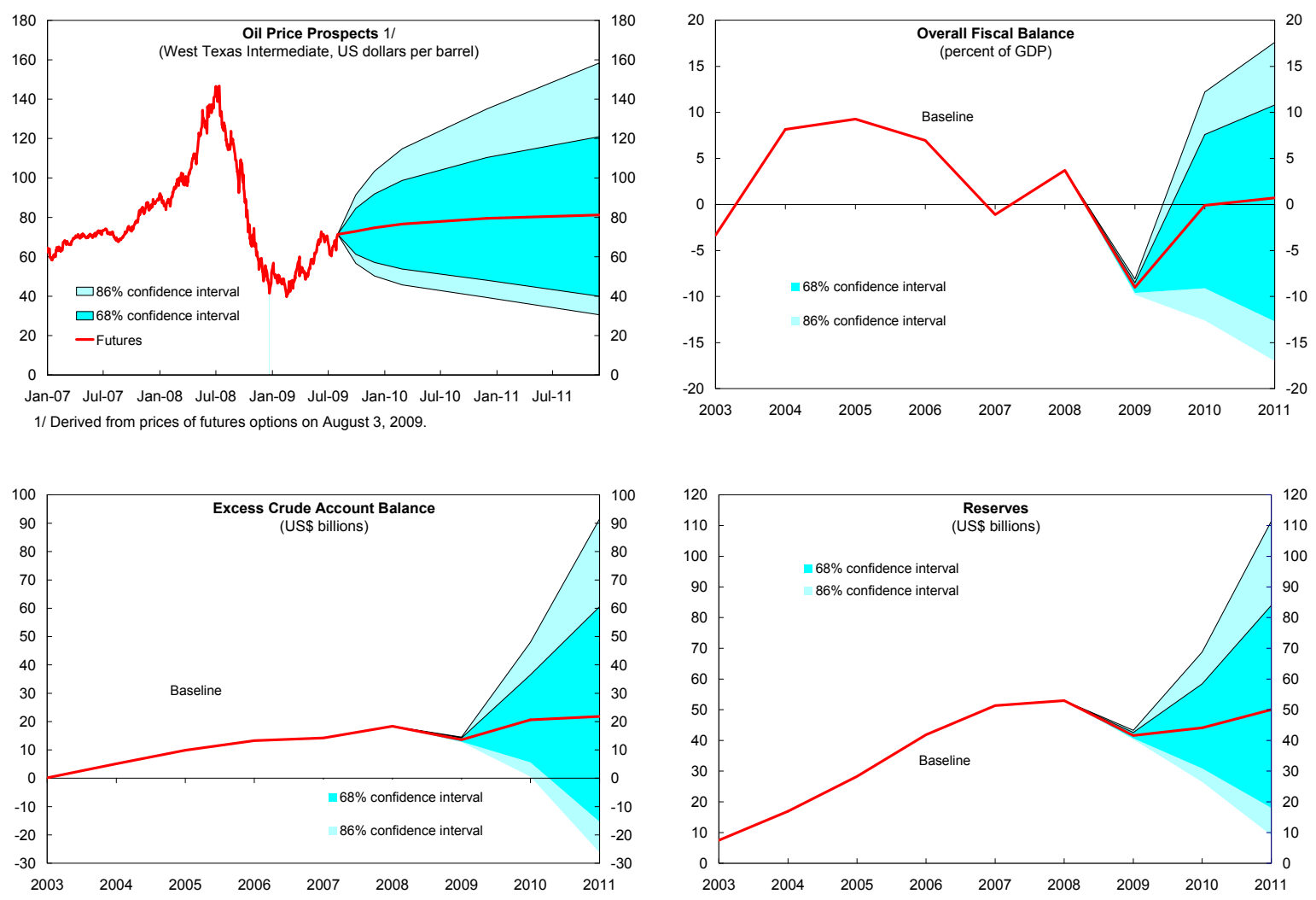

Sources: Bloomberg and IMF staff calculations

- The top left panel shows market expectations of oil prices in the form of an implied probability distribution derived from options prices.

- The associated risks to the fiscal and external accounts are then illustrated. Public spending, imports, and the exchange rate are held constant at their baseline levels, so that the full impact of adjustment falls on foreign reserves and the excess crude account. 


\section{Setting the Policy Course Following the Global Financial Crisis}

With signs that macroeconomic and financial conditions may be starting to stabilize, discussions focused on the importance of articulating a macroeconomic and financial policy framework that could support a return to strong economic growth and steer the economy through an unusually uncertain period.

\section{A. Fiscal Policy - Options in a Low Growth Environment}

Lower than trend growth argues for an accommodative fiscal policy. The scope for such a policy depends critically on financing and administrative capacity.

\section{The design of the fiscal policy regime is based on a medium-term framework} using the oil-price-based fiscal rule. The purpose of the regime, developed in 2004, was to insulate public spending from short-term oil sector developments and ensure that spending is consistent with inflation goals. Recent experience suggests that a non-oil primary deficitthe best available measure of how fiscal policy affects the domestic economy - of around 25 percent of non-oil GDP for the consolidated government is the appropriate medium-term fiscal anchor.

16. An accommodative fiscal stance relative to the medium term benchmark could mitigate the impact on growth of the global crisis. With growth expected to be well below potential in 2009 and 2010, tempering the speed with which the non-oil primary balance is brought back toward the medium-term benchmark would help support economic activity without generating inflationary concerns. ${ }^{5}$

\section{Financing constraints have limited the scope for fiscal support of activity in} 2009. Apart from the decline in oil revenues of 20 percent of non-oil GDP, ambitious targets for non-oil revenues are unlikely to materialize and a planned sovereign bond issue of $\$ 500$ million ( 0.5 percent of non-oil GDP) has been shelved because of market conditions. These shortfalls will be only partially offset by increased domestic borrowing, oil savings, the use of unspent account balances, and support from multilateral development banks. The consolidated government non-oil primary deficit is therefore expected to fall from 31 percent of non-oil GDP in 2008 to about 27 percent in 2009.

\footnotetext{
${ }^{5}$ Staff analysis suggests that this trajectory is consistent with preserving oil wealth for future generations, even without taking into account the potentially high returns from infrastructure spending and other investments.
} 
Nigeria: Consolidated Government Finances

(Percent of non-oil GDP, unless otherwise stated)

\begin{tabular}{lrrrrr}
\hline & & & & \\
& 2007 & 2008 & & 2009 & 2010 \\
\cline { 2 - 3 } \cline { 5 - 6 } & Act. & Act. & & Prel. & Proj. \\
\hline Revenues & 45.2 & 53.1 & 31.4 & 43.3 \\
$\quad$ of which: oil and gas revenue & 34.8 & 43.0 & 21.1 & 32.7 \\
Expenditure & 40.5 & 47.1 & 44.0 & 43.5 \\
$\quad$ Federal government & 15.4 & 17.3 & 16.8 & 15.6 \\
$\quad$ State and local government & 17.0 & 23.2 & 16.8 & 17.1 \\
$\quad$ Extrabudgetary and power sector projects & 7.7 & 5.8 & 9.6 & 10.8 \\
Non-oil primary balance & -30.3 & -30.8 & -27.0 & -27.0 \\
& & & & \\
Overall balance (percent of GDP) & -1.1 & 3.7 & -9.0 & -0.1 \\
Memorandum items: & & & & \\
Real primary spending (percent change) & 16.4 & 4.3 & -2.1 & 3.2 \\
Excess crude acount balance (US\$ billions) & 14.2 & 18.3 & 13.6 & 20.6 \\
\hline SOrces: Niger
\end{tabular}

Sources: Nigerian authorities and IMF staff

18. Financing constraints on the budget should ease in 2010. Projected oil prices and production levels should ease financing constraints subject to the level of the budget oil price in the 2010 budget. It will be important, however, to use some of this additional financing to scale back domestic borrowing from this year's peaks. Lower domestic borrowing is needed to allow room for a recovery in private sector borrowing as activity picks up.

19. Implementation capacity will limit the pace at which spending can be scaled up. A consolidated non-oil primary deficit for 2010 similar to the anticipated outturn for this year, would allow for a real increase in primary spending of about 3 percent. While there is still a case for a more accommodative stance from a cyclical perspective, it would be difficult to scale up spending substantially beyond these levels without compromising the quality of spending projects, including at the state and local governments where administrative capacity is limited (Box 2).

20. The authorities emphasized that their priority has been to support economic activity through better budget execution and public financial management. Federal capital spending has fallen well short of budgeted levels in recent years, The authorities indicated that the early start to the 2010 budget preparations, improved integration of medium-term sector strategies into the budget process, and increased familiarity with new procurement procedures should pave the way for better selection and execution of capital projects. 


\section{Box 2: Public Financial Management Reforms in State and Local Governments ${ }^{1 /}$}

State and local governments account for almost half of public spending. Better public financial management at the subnational level is essential to achieve spending priorities.

The World Bank has conducted public expenditure reviews and public expenditure and financial accountability assessments in 7 out of 36 states. These have highlighted a number of challenges, including:

- Limited budget credibility, reflected in large gaps between approved budgets and outturns.

- Limited and opaque budget reporting, with significant extra-budgetary operations.

- Poor alignment of resource allocation with state development priorities.

- Ineffective budget execution, on account of poor revenue forecasts and monitoring, and weak cash management.

- Deficiencies in accounting, recording, and reporting systems. Account reconciliations are not timely and in-year budget reporting is either irregular or not done. A major problem is the poor quality and timeliness of annual financial statements.

- Relatively good external audit systems, but significant flaws in the scrutiny and follow-up of audit recommendations.

Since late 2005, the World Bank's State Governance Capacity Building Project has provided support to three states to help them improve the management of their financial and human resources. It has provided assistance with accounting and financial reporting, external audit, budget preparation, improving the regulatory framework for public financial management (fiscal responsibility and procurement legislation and reforms), modernization of tax administration, personnel and payroll management and capacity building.

The main achievements have been: (i) strengthened tax administration to improve internally generated revenue; (ii) more timely and transparent reporting; and (iii) reforms and audits of personnel and payroll that have reduced fraud. Remaining priorities include implementation of integrated financial management systems and promotion of improved budget preparation. The Bank is planning to provide support to another 4 states in the second phase of the project.

${ }^{1 /}$ Prepared by World Bank staff.

\section{B. Setting Monetary Policy in the Face of Conflicting Goals}

Anchoring inflation expectations in line with the single-digit target calls for articulation and consistent implementation of the monetary and exchange rate regime. Competing concerns about inflation, exchange rates, international reserves, and financial stability have challenged monetary policy and operations. 
21. Inflation performance was much improved until the second half of 2008. Nigeria has a history of high inflation; inflation averaged about 15 percent in the first half of the decade and about 30 percent in the 1990s. In 2006-2007, more effective management of the monetary aggregates and reform-related increases in money demand kept inflation to its single-digit target.

22. The acceleration in inflation in $\mathbf{2 0 0 8}$ was broad-based. While supply related food price developments played a role in the rise in inflation and its more recent retreat, disaggregated price indices suggest that inflation was a broader phenomenon than supply related factors. A trimmed-mean measure of core inflation accelerated in 2008, averaging 15 percent in the second half of the year (Figure 6).

23. The rapid growth of the monetary aggregates likely helped push up inflation in 2008. When oil prices were surging in 2008 , monetary policy was geared to preventing appreciation of the naira against the US dollar by restraining foreign exchange sales. Because the resulting accumulation of reserves was not sterilized fully, monetary aggregates accelerated, with broad money and private credit increasing by about 60 percent by the end of 2008 .

24. Triggered by the crisis, a reversal of monetary expansion is bringing inflation back to its single-digit target. Broad money growth (quarter-on-quarter) abruptly turned negative in the second quarter of 2009. The central bank sought to limit pressure on the naira from lower oil prices and became a net seller of foreign exchange. Banks have reined in their lending. The slowdown in activity and tight credit conditions should dampen inflationary pressures considerably and offset the impact of naira depreciation on prices.

\section{Monetary operations were challenged by financial stability considerations and} fiscal developments resulting in high and volatile interest rates. As in other countries, after the crisis began, concerns about banks' balance sheet risks led to a breakdown in the interbank market. This contributed to higher interest rates in the interbank market and competition for liquidity in the retail market that pushed up deposit and lending interest rates. Moreover, the mechanism for disbursing government oil revenues leads to large and variable injections of liquidity that contribute to the volatility of interest rates.

\section{Effective communication of the framework and its implementation will be} critical for anchoring market expectations. A clear published statement of the monetary policy framework would help market participants to understand the basis for policy decisions. Similar communication of foreign exchange market policy and publication of central bank foreign exchange activity would also be desirable. 
Figure 6: Inflation and Monetary Developments

Inflation has begun to decelerate...

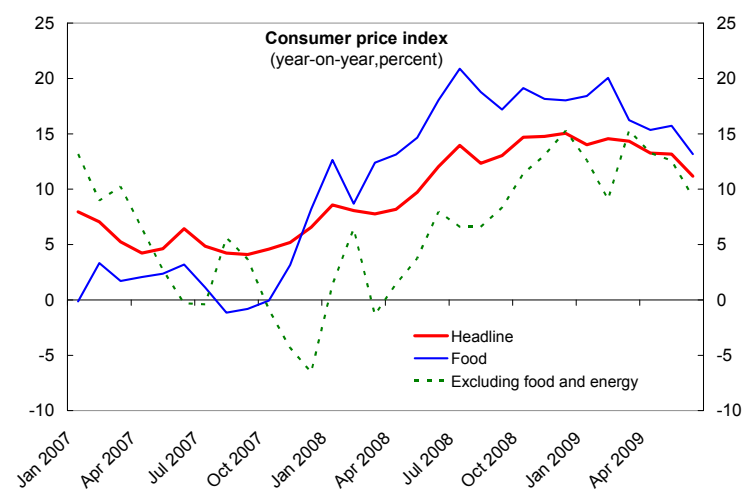

After a period of rapid money growth, monetary conditions have tightened considerably

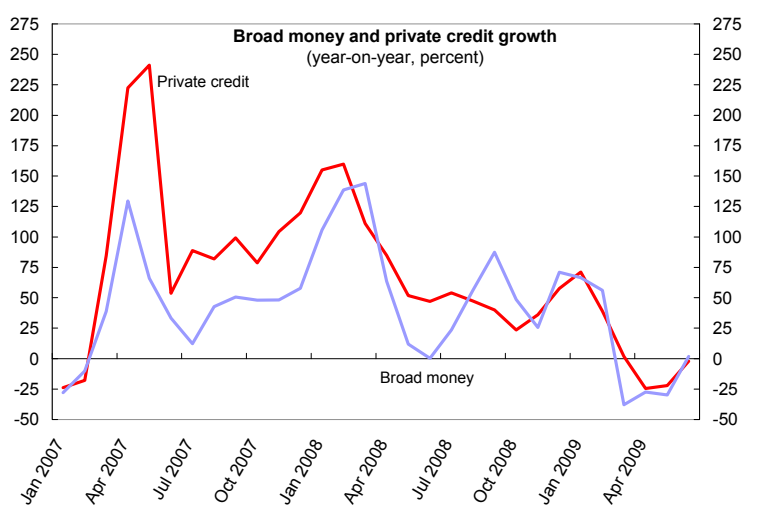

Interbank market strains, reflected in banks' preference for government paper, may be easing

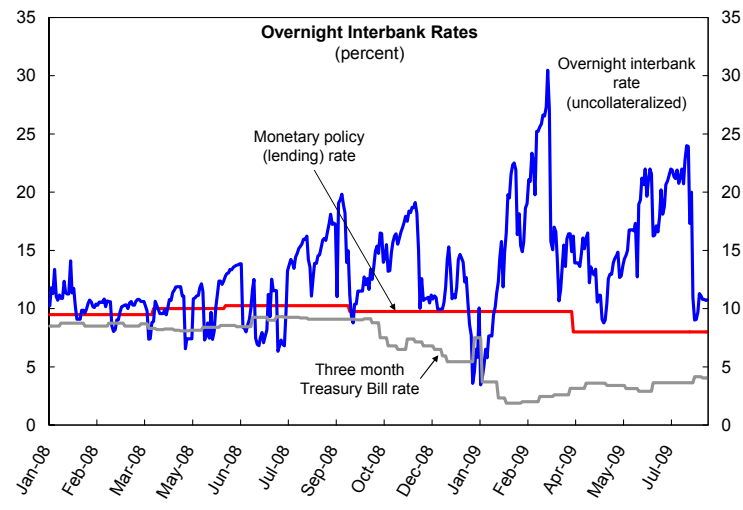

... and a trimmed means measure of core inflation has also begun to fall

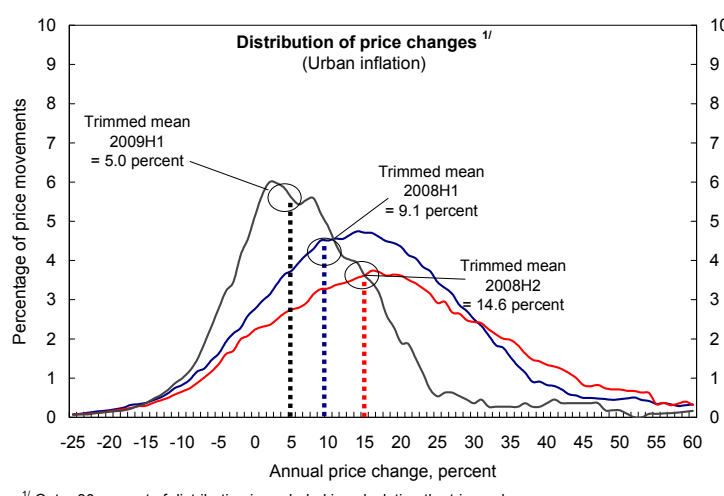

The slowdown in private credit has been led by a large residual "other" category

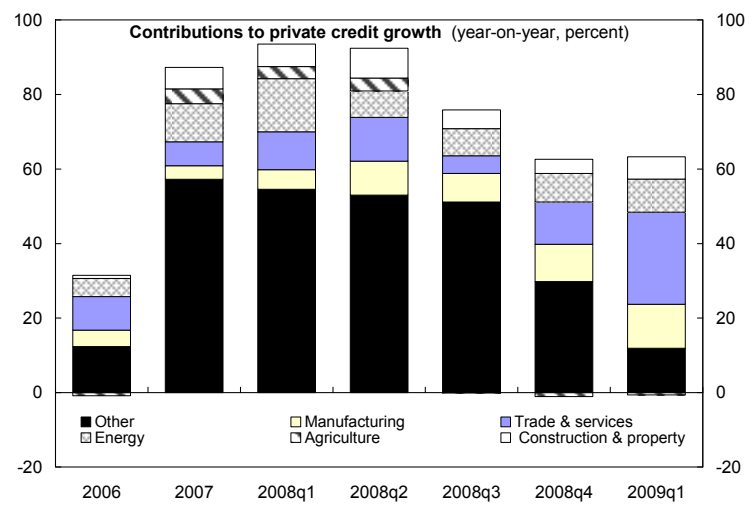

...but lending rates remain high and unresponsive to policy signals

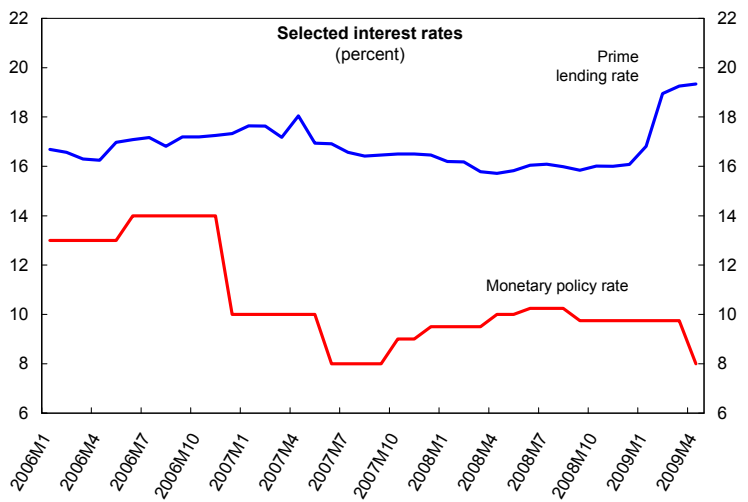

Sources: Nigerian authorities and IMF staff estimates. 
27. Monetary policy should focus on price stability with a well-defined nominal anchor. Staff argued that policy should be based on the relationship between monetary aggregates and inflation, leaving the exchange rate to respond flexibly to sustained external shocks. This would be superior to relating interest rates directly to the inflation goal at this stage of Nigeria's financial market development. Policy interest rates do not yet fully influence credit market conditions and tend to play a correspondingly small role in influencing economic activity. Over time, however, the central bank should move to inflation-targeting and set interest rates based on expected inflation.

28. The implementation of the monetary regime faces some challenging issues in Nigeria. In view of the changes in the economy, especially the rapid growth of the financial sector, policymakers need to pay close attention to factors that affect the demand for money for a given rate of inflation. Given the importance of food in domestic consumption, it would also be important to understand clearly the role of supply shocks, such as weather-related disruptions of food production.

29. The foreign exchange regime needs to permit flexibility in the naira rate to avoid undermining monetary policy. The pivotal role of the central bank, which is often the only provider of foreign exchange to the market (particularly since the onset of the crisis), complicates its policy task. The central bank needs to permit the exchange rate to be guided by fundamentals without being trapped on one side of the market as the sole seller (or buyer) of foreign exchange. Effective central bank intervention in the foreign exchange market may be necessary to ensure that market players see a two-way risk to taking foreign exchange positions.

30. The authorities intend to publish their monetary policy framework. They agree on the use of the monetary aggregates as the operating target for monetary policy (Box 3). They noted, however, that other considerations are important. For instance, they see an important role for monetary policy in promoting economic development by ensuring that interest rates are as low as possible consistent with their inflation target. Moreover, they are concerned about large swings in the exchange rate, noting that the economy is import dependent, including for basic items that affect the poor. They also observed that, in the absence of a non-oil export sector, there is intense political opposition to a weaker naira.

31. Retail interest rates that are relatively high compared to interbank and policy rates underscore the importance of addressing structural issues in the banking system. Market participants indicated that these impediments include the high cost base for banks, weaknesses in commercial bankruptcy law, and the absence of effective credit bureaus. The absence of a well-functioning corporate bond market leaves banks with a near monopoly in financing businesses. Corporate bond issuance would be promoted by significantly reducing regulatory costs in terms of both fees and administrative costs. 


\section{Box 3: The Monetary Policy Regime}

The central bank uses a monetary targeting regime. Under this regime, it uses policy instruments to influence its targets, the reserve and broad money aggregates; the ultimate goal of its interventions is to keep inflation in single digits. This goal is consistent with supporting growth and minimizing the harmful consequences of inflation, particularly for low-income groups.

A central component of policy is the interest rate corridor around the monetary policy rate (MPR). The central bank intervenes in the money market through the interest rate corridor, where the rate on a standing lending facility constitutes the ceiling and the rate on the standing deposit facility is the floor. The MPR is the midpoint between these rates. By adjusting this corridor, the central bank seeks to influence interest rates in the interbank market and thus the willingness of banks to hold naira.

Open market operations and reserve requirements are also used to help manage liquidity. Each week the central bank auctions treasury bills and, less frequently, federal government bonds. A repurchase (repo) market complements open market operations. The central bank also modifies bank reserve requirements to influence liquidity.

In conducting monetary policy, the central bank is also cognizant of other considerations. To keep interest rates as low as possible to support economic activity, the central bank promotes reforms in the banking and other sectors. Likewise, while recognizing that the exchange rate will move according to changes in the global and domestic economy, the central bank stands ready to dampen abrupt moves in the exchange rate.

\section{Financial Stability—Supporting Growth While Managing Risks}

Domestic factors and the global crisis have triggered significant problems in the banking system. The financial stability framework needs to be strengthened.

32. The banking system has expanded rapidly in recent years. In advance of the 2005-06 consolidation the banking system was chronically weak; of the 89 banks, marginal or unsound banks accounted for about 20 percent of system assets and the system's nonperforming loan ratio hovered around 20 percent. Consolidation transformed the system resulting in the current 24 banks with a substantial increase in capital. Many banks raised significant further capital following consolidation. Financial intermediation increased significantly. Bank branches grew from 2,900 in 2005 to almost 5,500 in mid-2009. Banks participated in a wider range of activities, including financing of infrastructure and the oil sector, which previously had been out of reach.

33. The pace of expansion posed challenges for supervisors. While the level of private credit in Nigeria at 21 percent of non-oil GDP was low before consolidation, its rapid growth since then to 50 percent of non-oil GDP by the end of 2008 argued for careful monitoring. Banks were under pressure to deploy and secure a return on their expanded 
capital. The central bank recognized the need for strengthened supervision and developed a plan for consolidated and risk-based supervision. But progress in implementation was slow.

34. The global crisis magnified the challenges facing the banking system. The immediate impact of global financial turbulence on the banking system was contained. While offshore funding of the domestic banking system was growing before the crisis, its scale was manageable and the central bank was able to accommodate commercial bank foreign exchange demand in the depth of the global crisis. Commercial banks did not have exposure to complex domestic or foreign financial instruments and foreign bank ownership was low. However, the large swing in oil prices, the resulting depreciation of the naira, and confidence effects in domestic capital markets, contributed to growing pressure on the banking system.

35. Concerns about bank balance sheets intensified as the crisis progressed. Market speculation about the quality of some bank balance sheets was evident in the breakdown of the naira interbank market as well as market perceptions, later verified, that some banks were using the central bank discount window as an ongoing source of funding. Some banks were involved heavily in margin lending for equity market investments. The equity market subsequently crashed by 70 percent reflecting both domestic and global market developments. In addition, some banks had high exposure to the importers of fuel products. The importers had high foreign currency obligations owing to the high fuel prices of earlier in 2008 and were then hit when oil prices plus the naira fell sharply thereby cutting their naira earnings.

36. Special examinations of bank balance sheets by the central bank and deposit insurance corporation were launched. The examinations sought to verify asset quality and examined related party transactions. Independent accounting firms reviewed the examinations. Some banks had sizable off balance sheet instruments that concealed nonperforming loans and while, in other cases, non-performing loans were rolled over or otherwise reclassified as performing. The examinations identified serious breaches of regulations and laws, including cases of connected lending. The central bank has required banks to bring on to their balance sheets exposures related to the capital market and to provision fully for any exposures that are deemed non-performing.

37. On the basis of the first round of examinations, which covered $\mathbf{1 0}$ banks, the central bank intervened in five banks in August 2009. Management of the banks was replaced and funds were injected into the banks. Capital adequacy and liquidity ratios in the intervened banks, which account for about one third of bank sector assets, fell short of regulatory requirements. About 40 percent of their loans were non-performing. The central bank provided N420 billion (about $\$ 2.8$ billion), equivalent to about $2 \frac{1}{2}$ percent of non-oil GDP, of liquidity support in the form of loans. The support was defined by determining the 
amount needed to notionally raise the capital adequacy of the banks to the regulatory requirement of ten percent plus a margin. ${ }^{6}$

38. The central bank plans to seek new capital for the intervened banks. The central bank has made a public commitment to protect depositors and creditors. The immediate goals are to stabilize the banks, seek full recapitalization through loan recovery and new investors, to strengthen the corporate governance practices in the banks, and to enable the central bank to remove itself from both the management and balance sheets of the banks.

\section{Looking ahead, there is a pressing need to develop a financial stability} framework to provide a solid foundation for the banking system. The recent experience has highlighted that there are legal and procedural questions in the current resolution arrangements. For example, it is not clear whether the central bank is permitted, under the central bank act, to take equity in a financial institution even as a transitory step in bank resolution. For the government to take the equity position would require an appropriation bill approved by the National Assembly. Such an appropriation cannot be secured in a timely manner. While the Central Bank and Nigeria Deposit Insurance Corporation legislation provides the legal framework for resolving banks, the questioning by some bank executives (and other interested parties) of the legal basis for these actions gives rise to the possibility of lengthy court involvement that could undermine the timely resolution of banks by the regulator.

40. Some elements of the financial stability framework are being introduced. The four main areas comprising the framework are:

- Macro prudential factors. Macroeconomic developments, including asset prices, need to guide supervisory and regulatory policy. The central bank intends to establish a macro prudential function in its supervision department.

- $\quad$ Prudential rules. The credibility of banks' balance sheets will be enhanced by the new requirement that banks move to a common reporting period by the end of 2009 and adopt IFRS accounting standards from the beginning of 2010. Decisions will also be needed on defining the scope of bank activities such as the pace with which derivative products can be developed given regulatory and supervisory capacity.

- Supervisory framework. The central bank's framework for risk-based and consolidated supervision needs to be implemented because a large number of banks

\footnotetext{
${ }^{6}$ The injection of liquidity could not formally be recorded as tier 2 capital in all cases. Tier 2 capital cannot exceed tier 1 capital. Hence, if the intervened bank had tier 1 capital of less than one half of the regulatory requirement (the case in two of the intervened banks) they remain below the regulatory capital requirement.
} 
have non-bank financial subsidiaries and cross-border activities. The number of foreign branches of Nigerian banks has expanded rapidly to 70 from only 4 in 2004 . Enhanced monitoring of banks' risk management practices, lending standards, and funding situation is warranted.

- Resolution framework. Allowing institutions to enter and leave the banking system based on the consequences of business decisions establishes strong incentives for banks to assess risks prudently. To enable this to occur without creating systemic distress, a framework must be established. The framework would make a clear statement of the conditions under which a troubled bank will be resolved by outlining principles, policies, and procedures for handling both a systemic crisis and the failure of an individual financial institution.

\section{Promoting Economic Growth and Diversification-Vision 2020}

A significant diversification of the economy away from oil and gas is the theme of Nigeria's Vision 2020 plan currently being prepared. Macroeconomic policy must create an enabling environment for private sector-led growth in the non-oil sector.

41. By 2020, Nigeria wants to become one of the world's top 20 economies. Vision 2020, now being prepared, sets out the authorities plan to achieve this goal by building a globally competitive economy that is much less reliant on the oil and gas sector to generate employment and reduce poverty.

\section{Establishing a macroeconomic policy framework that supports growth and} economic diversification will be essential. This calls for enhancing competitiveness through structural reforms and investment in critical infrastructure as well as ensuring that the exchange rate does not become overvalued. ${ }^{7}$ In this regard, resource producers that have successfully managed swings in commodity prices have done so by adopting strongly counter-cyclical fiscal policies. Nigeria's economic history demonstrates how letting swings in commodity prices drive fiscal policy can play havoc with development goals.

\section{Fiscal policy needs to neutralize the macroeconomic impact of swings in oil} prices. The oil-price-based fiscal rule has been instrumental in avoiding the boom bust pattern of earlier cycles. Diversification has begun to take place: non-oil GDP growth has been higher than in the oil sector and new growth drivers, such as telecommunications and financial services, have emerged. These reforms need to be sustained and extended through consistent implementation of the oil-price based fiscal rule. Extraordinary distributions from

\footnotetext{
${ }^{7}$ There is general agreement that an overvalued real exchange rate has a detrimental impact on economic growth (see, for example, Spence, 2008, The Growth Report: Strategies for Sustained Growth and Inclusive (Washington: World Bank)).
} 
the Excess Crude Account in response to political pressures to spend oil revenue windfalls have meant that fiscal policy has still been pro-cyclical during the current oil cycle. ${ }^{8}$

44. Private sector-led growth calls for a reduction in the size of the public sector. Despite recent increases in public capital expenditure, there is still a large infrastructure gap, and the costs of meeting the Millennium Development Goals will also be significant. Both of these factors will place demands on public resources in the next few years. Over time, however, the size of the public sector should gradually be scaled back to make room for private sector led-growth.

\section{To achieve these goals, the difficult issue of institutionalizing practices} concerning the management of oil wealth and revenue flows must be tackled. Some countries have used special fiscal institutions such as fiscal rules, commodity funds, or fiscal responsibility legislation to help deliver this outcome (Box 4). Beyond the current use of the Excess Crude Account and the Fiscal Responsibility Act, the authorities have considered setting up a national Sovereign Wealth Fund. ${ }^{9}$

\footnotetext{
${ }^{8}$ A 2007 memorandum of understanding between the tiers of government sought to formalize extraordinary allocations (i.e., beyond those to cover shortfalls in budget oil revenue) through the establishment of the 80-20 rule: 80 percent of oil savings accrued in a particular year would be available for additional spending the following year. This understanding, if implemented, runs counter to the objectives set by Vision 2020.

${ }^{9}$ The Fiscal Responsibility Act prescribes procedures for formulating, executing, and publishing the annual budget and medium-term expenditure framework, and sets out the role of the budget oil price. It also contains a rule limiting the overall budget deficit to 3 percent of GDP, with only a very restrictive escape clause.
} 


\section{Box 4. Experience with Fiscal Rules in Selected Commodity Producing Countries}

Some countries have found rule-based frameworks helpful in keeping spending growth moderate and smooth during commodity price booms:

- Chile's fiscal policy has been based on maintaining a structural central government balance target over the economic and copper price cycles. A feature is the use of independent experts to compute the extent to which output lies above or below potential, and to compute the extent to which the price of copper lies above or below its long-run level.

- Botswana's framework incorporates goals for the overall balance and a "golden rule" whereby non-mineral revenue should at least cover non-investment recurrent spending.

- Norway seeks to limit the central government structural non-oil deficit to no more than the expected long-run real rate of return on the accumulated financial assets in its oil fund. The guidelines allow deviations for countercyclical fiscal policy and are seen as a tool to help set a long-term benchmark for fiscal policy.

- Timor-Leste has relatively flexible guidelines. Fiscal policy is based on the non-oil deficit consistent with the estimated permanent income from oil wealth, but deviations are allowed so long as the government provides a rationale and information on the impact on oil wealth in future years.

Critical to success have been good institutions, transparency, and a high degree of political commitment to fiscal discipline. Lacking these factors, several countries have tried and failed despite efforts to make the rules as rigid as possible.

\section{Meeting spending priorities while allowing for medium-term fiscal consolidation calls for efforts on a number of fronts:}

- $\quad$ Prioritizing spending. The authorities have taken an important first step by proposing to eliminate subsidies on the remaining two subsidized fuel products; this will generate savings of about 2-4 percent of non-oil GDP.

- $\quad$ Strengthening non-oil tax performance. A draft National Tax Policy proposes reforms in a range of areas. Caution is warranted in considering proposals for extensive tax incentives, in terms of both the implications for achieving development goals and designing such incentives cost-effectively.

- Identifying areas for private sector initiatives. Two areas identified are Public Private Partnerships (PPPs) and corporatization of public sector involvement in upstream oil sector development, which would reduce the call on the budget for investment in the oil sector. Both areas require establishing a regulatory and legal framework including to manage the associated fiscal risks.

- Boosting the quality of spending. The increased focus on performance indicators with a view to the adoption of program-based budgeting is a major initiative. It will also be 
important to build on steps already taken to improve budget planning by, for example, increasing the effectiveness of the medium-term sector strategies in evaluating projects.

\section{E. Charting a Course for the Oil and Gas Sector}

While the Vision 2020 plans to diversify the economy are important, the oil and gas sector will remain a critical determinant of macroeconomic performance and the primary source of exports and government revenue for the foreseeable future. Draft legislation proposes a major overhaul of the sector.

47. The authorities are considering a wholesale reform of the petroleum industry. The draft Petroleum Industry Bill would replace 16 existing laws and a myriad of administrative instruments into a single omnibus law establishing a new legal and regulatory framework for the industry. Among the objectives it seeks to achieve are:

- Promotion of good governance and transparency, by publishing all procedures, contracts, and payments. Prospecting licenses and mining leases would be subject to competitive bidding. The Bill would also be consistent with the Nigerian Extractive Industries Transparency (NEITI) Act. ${ }^{10}$

- Separation of the government's commercial and regulatory roles, including the establishment of a viable and self-financing national oil company. The Bill envisages a new national oil company to form incorporated joint ventures with international oil companies that can finance new projects directly from cash flow and borrowing.

- Establishing a fiscal framework involving increased emphasis on royalties. Royalty rates would be adjusted depending on production volumes and prices and would vary by geographical location (onshore, shallow offshore, deep offshore, and inland basins) to account for differences in costs and risk.

48. The review of the oil and gas regime is an opportunity to enhance arrangements, but care needs to be taken to ensure that the industry remains attractive to investors. The tax regime needs to both maximize returns to government and promote investment in the sector; this requires detailed quantitative analysis and careful design of transitional arrangements. For gas especially, it will be important to identify and address price, payment, regulatory and other impediments that have held back the development of a vibrant downstream gas industry, despite a generous tax regime for upstream production.

49. Current tax arrangements vary according to the type of contract; there may be scope to increase the return to government in some cases. A preliminary assessment of

\footnotetext{
${ }^{10}$ The first set of NEITI audits for 1999-2004 were published in 2006 and a second audit report for 2005 was published in 2009. Audits for 2006-08 are being commissioned.
} 
current fiscal terms, based on comparisons of the estimated average effective tax rate with those of other oil producing countries, suggests that the average effective tax rate for onshore joint venture (JV) arrangements is high by international standards (Figure 7), although the terms for production sharing contracts (PSCs), which were agreed to in 1993 to encourage investors to explore offshore, are more generous. ${ }^{11}$

Figure 7: Average Effective Tax Rates in Selected Oil Producing Countries
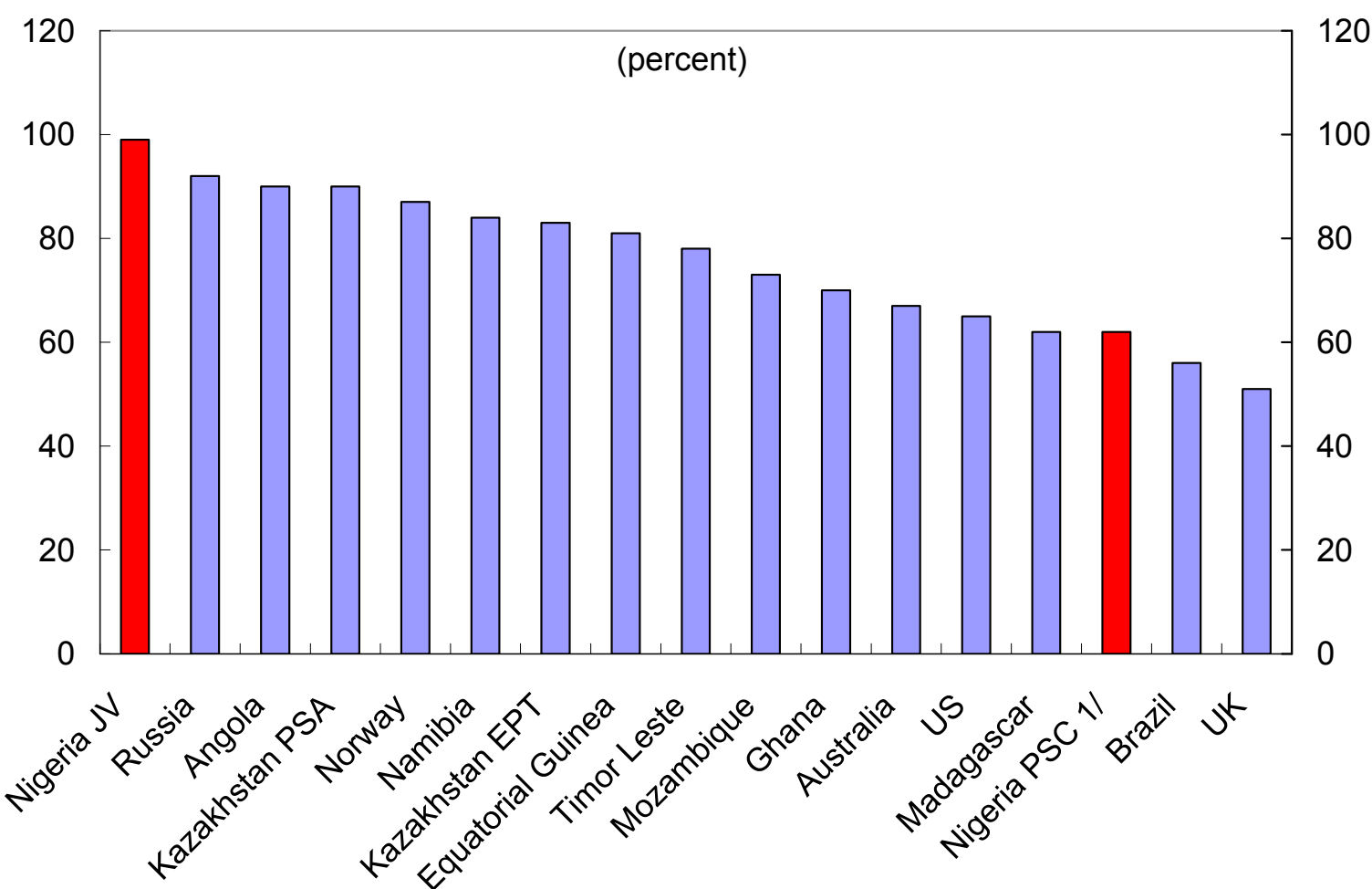

1/ The terms for PSCs vary. The PSC shown refers to the deep water PSC of 1993.

Sources: Nigerian authorities and IMF staff estimates.

50. Policy and administrative considerations will affect the choice of a future fiscal regime. Among them are the responsiveness of government to oil prices and the costs of production. Reliance on revenue-based instruments is attractive because they are easier to administer and so reduce scope for tax avoidance. However, they have the serious drawback that they are not responsive to the cost structure of different oil and gas projects and so run the risk of discouraging investment.

\footnotetext{
${ }^{11}$ The average effective tax rate is the ratio of government revenues to the before-tax net cash flow from the project, both expressed in real net present value terms, calculated over the estimated life of a representative oil field.
} 


\section{Staff Appraisal}

51. Though growth has slowed from the impressive rates of recent years, reforms initiated earlier this decade have done much to soften the impact of the global financial crisis on Nigeria. The substantial cushion of oil savings and foreign reserves built up when oil prices were surging, together with bank consolidation and recapitalization, have enabled policy makers to manage the crisis fallout from a position of strength. However, the outlook remains challenging and highly dependent on developments in oil prices; growth is likely to remain weaker than trend.

52. The growth outlook calls for a supportive fiscal stance, but financing and administrative capacity constraints limit the scope for this support. The authorities' emphasis on improved budget execution and enhanced public financial management is welcome. Faced with a precipitous decline in oil revenues, the availability of oil savings and room to increase borrowing averted the need for an equally deep fiscal contraction. Nonetheless, financing constraints and lack of implementation capacity have limited the scope for fiscal stimulus. The uncertain outlook for oil revenues also warrants the prudent approach followed by the authorities.

53. A clearly articulated monetary policy framework would help anchor inflation expectations. A robust framework would help guide policy through competing concerns about inflation, external developments, and financial stability, which have been a challenge for monetary policy and operations in recent years. The authorities' intention to publish their monetary policy framework is welcome. Consistent implementation of the framework, based on the relationship between monetary aggregates and inflation, and its effective communication will be critical in anchoring market expectations. Over time, the authorities should pursue their goal of adopting an inflation-targeting framework.

54. The increased flexibility of the exchange rate in recent months is positive. It will support the implementation of monetary policy focused on price stability, while allowing the naira to find its equilibrium level. A more consistent regime will help to reduce uncertainty and build policy credibility following the recent frequent changes of foreign exchange regulations. In the staff's view, the level of the naira is consistent with external stability.

55. The authorities are taking welcome measures to resolve problems in bank

balance sheets. The banking system has been transformed in recent years, but sustaining that success calls for decisive action to address weaknesses in some banks. While the system as a whole has significant capital, individual banks that pursued high-risk strategies during the recent period of rapid credit growth are demonstrably vulnerable. The next step is to take the necessary actions to normalize the banking system consistent with financial stability considerations. 
56. A robust financial stability framework will be important for the sustained development of the financial sector. Improvements are already in train, including steps to improve the credibility of information on bank balance sheets and to establish a macro prudential unit within the central bank. Preparatory steps have also been taken to develop a framework for risk-based and consolidated supervision: this framework now needs to be implemented. Beyond this, the rapid expansion of Nigerian banks across borders calls for stronger cross-border supervisory arrangements. A clear framework for dealing with bank failures also needs to be spelled out.

57. Macroeconomic policies are decisive in supporting private sector-led growth, diversifying the economy, and further reducing poverty. Building on past progress in managing swings in commodity prices, fiscal policy will need to be more consistently counter-cyclical — ad hoc or discretionary distributions of oil savings have generally operated in the opposite direction. This underscores the importance of tackling the difficult issue of institutionalizing practices concerning the management of oil wealth and revenue flows.

58. The proposed overhaul of the framework for the oil and gas sector is an opportunity to improve arrangements in a sector that will remain critical from a macroeconomic perspective. The authorities' goals of improving governance, enhancing transparency, and creating an efficient fiscal regime that remains attractive to investors, are fully appropriate. Achieving them will require further detailed quantitative analysis and careful design of transitional arrangements.

59. Staff recommends that the next Article IV consultation be held on the standard 12month cycle. 
Table 1. Nigeria: Selected Economic and Financial Indicators, 2006-14

\begin{tabular}{|c|c|c|c|c|c|c|c|c|c|}
\hline & 2006 & 2007 & 2008 & 2009 & 2010 & 2011 & 2012 & 2013 & 2014 \\
\hline & Act. & Act. & Act & Est. & & & Proj. & & \\
\hline \multicolumn{10}{|c|}{ National income and prices (annual percentage change, unless otherwise specified) } \\
\hline Real GDP (at 1990 factor cost) & 6.0 & 6.4 & 6.0 & 2.9 & 5.0 & 5.2 & 5.9 & 6.2 & 6.3 \\
\hline Oil and Gas GDP & -4.5 & -4.5 & -6.2 & -4.8 & 6.0 & 5.4 & 7.3 & 6.4 & 5.4 \\
\hline Non-oil GDP & 9.4 & 9.5 & 9.0 & 4.5 & 4.8 & 5.2 & 5.7 & 6.2 & 6.5 \\
\hline Production of crude oil (million barrels per day) & 2.36 & 2.21 & 2.09 & 2.06 & 2.11 & 2.21 & 2.35 & 2.49 & 2.61 \\
\hline Nominal GDP at market prices (trillions of naira) & 18.7 & 20.9 & 24.6 & 25.2 & 30.9 & 35.6 & 41.2 & 47.6 & 54.9 \\
\hline Nominal non-oil GDP at factor cost (trillions of naira) & 11.6 & 13.1 & 15.2 & 17.8 & 20.4 & 23.3 & 26.7 & 30.8 & 35.6 \\
\hline Nominal GDP per capita (US\$) & 1,039 & 1,153 & 1,401 & 1,089 & 1,191 & 1,244 & 1,306 & 1,375 & 1,445 \\
\hline GDP deflator & 19.5 & 4.3 & 11.0 & -0.3 & 16.7 & 9.7 & 9.1 & 8.9 & 8.5 \\
\hline Non-oil GDP deflator & 18.8 & 3.5 & 6.3 & 12.3 & 9.1 & 8.6 & 8.5 & 8.5 & 8.5 \\
\hline Consumer price index (annual average) & 8.2 & 5.4 & 11.6 & 12.0 & 8.8 & 8.5 & 8.5 & 8.5 & 8.5 \\
\hline Consumer price index (end of period) & 8.5 & 6.6 & 15.1 & 9.1 & 8.5 & 8.5 & 8.5 & 8.5 & 8.5 \\
\hline \multicolumn{10}{|c|}{ Consolidated government operations (consists of federal, state, and local governments; percent of GDP) } \\
\hline Total revenues and grants & 33.9 & 28.4 & 32.8 & 22.2 & 28.6 & 28.8 & 29.1 & 29.2 & 29.1 \\
\hline Of which: oil and gas revenue & 29.1 & 21.9 & 26.6 & 15.0 & 21.6 & 21.8 & 22.1 & 22.1 & 22.1 \\
\hline Total expenditure and net lending & 26.9 & 29.5 & 29.2 & 31.2 & 28.7 & 28.1 & 27.5 & 27.3 & 26.8 \\
\hline Overall balance & 7.0 & -1.1 & 3.7 & -9.0 & -0.1 & 0.7 & 1.6 & 1.9 & 2.3 \\
\hline Non-oil primary balance (percent of non-oil GDP) & -29.5 & -30.3 & -30.8 & -27.0 & -27.0 & -26.6 & -25.9 & -25.7 & -25.1 \\
\hline Excess crude account (US $\$$ billions) ${ }^{1}$ & 13.2 & 14.2 & 18.3 & 13.6 & 20.6 & 21.8 & 26.2 & 30.0 & 33.8 \\
\hline \multicolumn{10}{|c|}{ Money and credit (change in percent of broad money at the beginning of the period) } \\
\hline Broad money & 53.4 & 44.2 & 57.8 & 19.3 & 24.8 & $\ldots$ & $\ldots$ & $\ldots$ & $\ldots$ \\
\hline Net foreign assets & 72.5 & 16.4 & 26.6 & -6.2 & 8.6 & $\ldots$ & $\ldots$ & $\ldots$ & $\ldots$ \\
\hline Net domestic assets & -15.7 & 27.8 & 31.1 & 25.5 & 16.2 & $\ldots$ & $\ldots$ & $\ldots$ & $\ldots$ \\
\hline Credit to consolidated government & -38.3 & -3.5 & -15.0 & 17.0 & 0.2 & $\ldots$ & $\ldots$ & $\ldots$ & $\ldots$ \\
\hline Credit to the rest of the economy & 22.6 & 54.8 & 50.2 & 11.4 & 15.2 & $\ldots$ & $\ldots$ & $\ldots$ & $\ldots$ \\
\hline Velocity & 2.9 & 2.3 & 1.7 & 1.6 & 1.5 & $\ldots$ & $\ldots$ & $\ldots$ & $\ldots$ \\
\hline Treasury bill rate (percent; end of period) & 7.4 & 8.7 & 5.4 & $\ldots$ & $\ldots$ & $\ldots$ & $\ldots$ & $\ldots$ & $\ldots$ \\
\hline \multicolumn{10}{|c|}{ External sector (annual percentage change, unless otherwise specified) } \\
\hline Current account balance (percent of GDP) & 26.5 & 18.8 & 20.4 & 6.9 & 13.8 & 14.3 & 14.8 & 14.7 & 14.5 \\
\hline Exports, f.o.b. & 16.9 & 15.9 & 26.3 & -39.3 & 29.5 & 9.2 & 9.1 & 8.6 & 7.7 \\
\hline Oil and gas export volume & -2.6 & 4.2 & -7.5 & -4.9 & 2.8 & 5.1 & 7.2 & 6.1 & 5.5 \\
\hline Imports, f.o.b. & -7.0 & 34.5 & 21.2 & -13.2 & -0.6 & 6.2 & 5.8 & 7.3 & 6.4 \\
\hline Terms of trade & 9.0 & 0.3 & 17.0 & -22.7 & 15.0 & 1.1 & 0.4 & 0.8 & 0.7 \\
\hline Price of Nigerian oil (US\$ per barrel) & 64.3 & 71.1 & 97.0 & 61.5 & 76.5 & 79.5 & 81.0 & 83.0 & 84.8 \\
\hline Nominal effective exchange rate (end of period) & 97.9 & 99.8 & 100.6 & $\ldots$ & $\ldots$ & $\ldots$ & $\ldots$ & $\ldots$ & $\ldots$ \\
\hline Real effective exchange rate (end of period) & 104.5 & 109.5 & 123.8 & & $\ldots$ & $\ldots$ & $\ldots$ & $\ldots$ & $\ldots$ \\
\hline External debt outstanding (US\$ billions) & 3.5 & 4.0 & 4.5 & 4.9 & 5.5 & 6.1 & 6.7 & 7.2 & 7.2 \\
\hline Gross international reserves (US $\$$ billions) ${ }^{2}$ & 41.8 & 51.3 & 53.0 & 41.6 & 44.1 & 50.0 & 59.4 & 71.1 & 84.6 \\
\hline (equivalent months of imports of goods and services) & 11.7 & 12.1 & 13.8 & 10.8 & 10.7 & 11.4 & 12.7 & 14.3 & 15.9 \\
\hline
\end{tabular}

Sources: Nigerian authorities and IMF staff estimates and projections.

${ }^{1}$ Including the naira-denominated component.

${ }^{2}$ Includes \$2.6 billion in 2009 on account of the SDR allocation 
Table 2a. Nigeria: Federal Government, 2006-10 (billions of naira)

\begin{tabular}{|c|c|c|c|c|c|}
\hline & $\begin{array}{c}2006 \\
\text { Act. }\end{array}$ & $\begin{array}{c}2007 \\
\text { Act. }\end{array}$ & $\begin{array}{c}2008 \\
\text { Act. }\end{array}$ & $\begin{array}{l}2009 \\
\text { Prel. }\end{array}$ & $\begin{array}{l}2010 \\
\text { Proj. }\end{array}$ \\
\hline Total revenue & 2,425 & 2,296 & 3,005 & 1,787 & 3,121 \\
\hline Oil revenue & 2,167 & 1,752 & 2,515 & 1,166 & 2,357 \\
\hline Non-oil revenue & 258 & 544 & 490 & 621 & 764 \\
\hline Total expenditure & 1,669 & 2,343 & 2,625 & 2,992 & 3,187 \\
\hline Recurrent expenditure & 1,174 & 1,569 & 1,958 & 2,174 & 2,337 \\
\hline Personnel & 665 & 915 & 1,081 & 1,018 & 1,136 \\
\hline Overheads & 223 & 347 & 471 & 335 & 371 \\
\hline Other service wide votes & 0 & 0 & 0 & 333 & 255 \\
\hline Interest & 187 & 205 & 244 & 278 & 361 \\
\hline Transfers $^{1}$ & 99 & 102 & 163 & 209 & 214 \\
\hline Capital expenditure & 495 & 774 & 667 & 818 & 850 \\
\hline Overall balance & 756 & -47 & 380 & $-1,204$ & -66 \\
\hline Financing & $-1,529$ & -993 & -347 & 1,204 & 66 \\
\hline External & -627 & -43 & -31 & 47 & -26 \\
\hline Borrowing & 0 & 0 & 0 & 91 & 8 \\
\hline Amortization & -52 & -43 & -31 & -44 & -34 \\
\hline Debt buyback & -576 & 0 & 0 & 0 & 0 \\
\hline Domestic & -931 & -963 & -316 & 1,051 & 92 \\
\hline Central bank & $-1,204$ & $-1,809$ & -35 & 347 & -508 \\
\hline Commercial banks & 273 & 847 & -282 & 704 & 600 \\
\hline Nonbank & 0 & 0 & 0 & 0 & 0 \\
\hline Other (including privatization and recovered funds) & 30 & 12 & 0 & 107 & 0 \\
\hline Statistical discrepancy & -773 & $-1,040$ & 34 & 0 & 0 \\
\hline
\end{tabular}

Sources: Nigerian authorities and IMFstaff estimates and projections.

${ }^{1}$ Includes earmarked spending for National Judicial Council, Universal Basic Education, and Niger Delta Development Corporation. 
Table 2b. Nigeria: Consolidated Government, 2006-10 (billions of naira)

\begin{tabular}{|c|c|c|c|c|c|}
\hline & $\begin{array}{c}2006 \\
\text { Act. }\end{array}$ & $\begin{array}{c}2007 \\
\text { Act. }\end{array}$ & $\begin{array}{c}2008 \\
\text { Act. }\end{array}$ & $\begin{array}{c}2009 \\
\text { Prel. }\end{array}$ & $\begin{array}{l}2010 \\
\text { Proj. }\end{array}$ \\
\hline Total revenue & 6,336 & 5,926 & 8,063 & 5,598 & 8,831 \\
\hline Oil revenue & 5,445 & 4,564 & 6,535 & 3,761 & 6,666 \\
\hline Non-oil revenue & 891 & 1,362 & 1,529 & 1,837 & 2,165 \\
\hline Import and excise duties & 178 & 241 & 281 & 300 & 355 \\
\hline Companies' income tax & 245 & 327 & 417 & 524 & 610 \\
\hline Value-added tax & 227 & 302 & 405 & 499 & 581 \\
\hline Other (education tax and customs levies) & 60 & 92 & 129 & 141 & 161 \\
\hline Federal government independent revenue & 33 & 243 & 115 & 175 & 242 \\
\hline SLG independent revenue & 148 & 158 & 182 & 199 & 215 \\
\hline Total expenditure & 5,033 & 6,149 & 7,159 & 7,859 & 8,870 \\
\hline Federal government & 1,669 & 2,343 & 2,625 & 2,992 & 3,187 \\
\hline Extrabudgetary funds ${ }^{1}$ & 212 & 367 & 265 & 345 & 437 \\
\hline State and local government & 2,362 & 2,582 & 3,529 & 3,004 & 3,485 \\
\hline Shared infrastructure spending & 194 & 205 & 0 & 245 & 624 \\
\hline Explicit fuel subsidy & 4 & 49 & 119 & 146 & 0 \\
\hline Other $^{2}$ & 592 & 603 & 622 & 1,128 & 1,137 \\
\hline Overall balance & 1,303 & -223 & 904 & $-2,262$ & -40 \\
\hline Financing & $-1,680$ & -988 & -511 & 2,262 & 40 \\
\hline External & -772 & -4 & 2 & 163 & 20 \\
\hline Borrowing & 64 & 53 & 43 & 222 & 66 \\
\hline Amortization & -69 & -57 & -41 & -59 & -46 \\
\hline Debt buyback & -767 & 0 & 0 & 0 & 0 \\
\hline Domestic & -937 & -997 & -513 & 1,993 & 20 \\
\hline Central bank & $-1,204$ & $-1,809$ & -35 & 857 & -580 \\
\hline Commercial banks & 267 & 812 & -479 & 1,136 & 600 \\
\hline Nonbank & 0 & 0 & 0 & 0 & 0 \\
\hline Other (including privatization and recovered funds) & 30 & 12 & 0 & 107 & 0 \\
\hline Statistical discrepancy & -377 & $-1,211$ & 393 & 0 & 0 \\
\hline \multicolumn{6}{|l|}{ Memorandum items: } \\
\hline Implicit fuel subsidy & 232 & 239 & 377 & 275 & $\ldots$ \\
\hline Total real spending (\% growth) & 17.3 & 16.4 & 4.3 & -2.1 & 3.2 \\
\hline FG real primary spending (\% growth $)^{3}$ & 28.8 & 36.8 & -0.2 & 1.8 & -4.3 \\
\hline SLG real primary spending (\% growth) ${ }^{3}$ & 14.6 & 3.7 & 22.7 & -24.0 & 6.6 \\
\hline Gross domestic debt ( $\%$ of GDP) & 11.8 & 12.8 & 11.6 & 15.0 & 14.7 \\
\hline
\end{tabular}

Sources: Nigerian authorities and IMFstaff estimates and projections.

${ }^{1 /}$ Includes spending of customs levies and education tax; transfers to FIRS and NCS; spending from the ecology, stabilization, development of natural resources accounts; and FCT spending.

${ }^{2 /}$ Includes cash calls and foreign-financed capital expenditure.

${ }^{3 /}$ Excludes contribution to shared spending 
Table 2c. Nigeria: Consolidated and Federal Government, 2006-10

(Percent of non-oil GDP, unless otherwise stated)

\begin{tabular}{|c|c|c|c|c|c|}
\hline & $\begin{array}{l}2006 \\
\text { Act. }\end{array}$ & $\begin{array}{l}2007 \\
\text { Act. }\end{array}$ & $\begin{array}{l}2008 \\
\text { Act. }\end{array}$ & $\begin{array}{l}2009 \\
\text { Prel. } \\
\end{array}$ & $\begin{array}{l}2010 \\
\text { Proj. }\end{array}$ \\
\hline \multicolumn{6}{|l|}{ Consolidated Government } \\
\hline Total revenue & 54.7 & 45.2 & 53.1 & 31.4 & 43.3 \\
\hline Oil and gas revenue & 47.0 & 34.8 & 43.0 & 21.1 & 32.7 \\
\hline Non-oil revenue & 7.7 & 10.4 & 10.1 & 10.3 & 10.6 \\
\hline Total consolidated expenditure & 43.5 & 46.9 & 47.1 & 44.0 & 43.5 \\
\hline Federal government & 14.4 & 17.8 & 17.3 & 16.8 & 15.6 \\
\hline Extrabudgetary & 1.8 & 2.8 & 1.7 & 1.9 & 2.1 \\
\hline State and local government & 20.4 & 19.7 & 23.2 & 16.8 & 17.1 \\
\hline Shared infrastructure spending & 1.7 & 1.6 & 0.0 & 1.4 & 3.1 \\
\hline Explicit fuel subsidy & 0.0 & 0.4 & 0.8 & 0.8 & 0.0 \\
\hline Other & 5.1 & 4.6 & 4.1 & 6.3 & 5.6 \\
\hline Overall balance & 11.3 & -1.7 & 5.9 & -12.7 & -0.2 \\
\hline Overall balance (percent of GDP) & 7.0 & -1.1 & 3.7 & -9.0 & -0.1 \\
\hline Non-oil primary balance & -29.5 & -30.3 & -30.8 & -27.0 & -27.0 \\
\hline ECA balance eop (billions of Naira) & 1,694 & 1,664 & 2,430 & 1,675 & 2,879 \\
\hline \multicolumn{6}{|l|}{ Federal Government } \\
\hline Total revenue & 20.9 & 17.5 & 19.8 & 10.0 & 15.3 \\
\hline Oil and gas revenue & 18.7 & 13.3 & 16.5 & 6.5 & 11.6 \\
\hline Non-oil revenue & 2.2 & 4.1 & 3.2 & 3.5 & 3.7 \\
\hline Total expenditure & 14.4 & 17.8 & 17.3 & 16.8 & 15.6 \\
\hline Recurrent expenditure & 10.1 & 12.0 & 12.9 & 12.2 & 11.5 \\
\hline Personnel & 5.7 & 7.0 & 7.1 & 5.7 & 5.6 \\
\hline Overheads & 1.9 & 2.6 & 3.1 & 1.9 & 1.8 \\
\hline Other service wide votes & 0.0 & 0.0 & 0.0 & 1.9 & 1.3 \\
\hline Interest & 1.6 & 1.6 & 1.6 & 1.6 & 1.8 \\
\hline Transfers & 0.9 & 0.8 & 1.1 & 1.2 & 1.0 \\
\hline Capital expenditure & 4.3 & 5.9 & 4.4 & 4.6 & 4.2 \\
\hline Overall balance (percent of GDP) & 4.0 & -0.2 & 1.5 & -4.8 & -0.2 \\
\hline Non-oil primary balance & -10.6 & -12.1 & -12.4 & -11.7 & -10.1 \\
\hline
\end{tabular}

Sources: Nigerian authorities and IMFstaff estimates and projections. 
Table 3a. Nigeria: Central Bank of Nigeria (CBN) Analytical Balance Sheet, 2006-10

\begin{tabular}{|c|c|c|c|c|c|c|c|c|c|c|}
\hline & \multirow{2}{*}{$\begin{array}{c}2006 \\
\text { Dec. }\end{array}$} & \multirow{2}{*}{$\begin{array}{l}2007 \\
\text { Dec. }\end{array}$} & \multicolumn{4}{|c|}{2008} & \multicolumn{3}{|c|}{2009} & \multirow{3}{*}{$\begin{array}{c}2010 \\
\text { Dec. } \\
\text { Proj. }\end{array}$} \\
\hline & & & Mar. & Jun. & Sep. & Dec. & Mar. & Jun. & Dec. & \\
\hline & \multicolumn{8}{|c|}{ Act. } & Proj. & \\
\hline Net foreign assets ${ }^{1}$ & 5,312 & 5,983 & 6,813 & 6,875 & 7,053 & 6,948 & 6,133 & 5,777 & 6,659 & 7,597 \\
\hline Net domestic assets & $-4,401$ & $-4,788$ & $-5,613$ & $-5,357$ & $-5,806$ & $-5,399$ & $-4,749$ & $-4,486$ & $-4,805$ & $-5,292$ \\
\hline Net domestic credit & $-2,451$ & $-3,107$ & $-3,912$ & $-3,774$ & $-4,493$ & $-4,135$ & $-3,582$ & $-3,266$ & $-3,150$ & $-3,731$ \\
\hline Net claims on consolidated government & $-2,491$ & $-3,487$ & $-4,038$ & $-3,837$ & $-4,547$ & $-4,139$ & $-3,760$ & $-3,414$ & $-3,298$ & $-3,879$ \\
\hline Excess crude account & $-1,708$ & -268 & -373 & -400 & -672 & -884 & -622 & -294 & 69 & $-1,091$ \\
\hline Net claims on federal government & -690 & $-3,103$ & $-3,526$ & $-3,291$ & $-3,723$ & $-3,095$ & $-2,985$ & $-2,974$ & $-3,236$ & $-2,611$ \\
\hline Statutory funds & -92 & -116 & -138 & -146 & -153 & -160 & -153 & -146 & -132 & -176 \\
\hline Other net claims & 40 & 380 & 126 & 62 & 54 & 3 & 177 & 148 & 148 & 148 \\
\hline Other items net & $-1,950$ & $-1,681$ & $-1,701$ & $-1,583$ & $-1,312$ & $-1,264$ & $-1,167$ & $-1,220$ & $-1,655$ & $-1,562$ \\
\hline Reserve money & 911 & 1,195 & 1,200 & 1,518 & 1,247 & 1,549 & 1,384 & 1,291 & 1,853 & 2,305 \\
\hline Currency in circulation & 779 & 961 & 892 & 918 & 976 & 1,155 & 1,038 & 1,007 & $\ldots$ & $\ldots$ \\
\hline Banks reserves with the CBN & 132 & 234 & 308 & 599 & 271 & 394 & 346 & 285 & $\ldots$ & $\ldots$ \\
\hline \multicolumn{11}{|l|}{ Memorandum items: } \\
\hline Reserve money y/y growth rate & 19.5 & 31.2 & 42.6 & 72.1 & 28.9 & 29.6 & 15.3 & -14.9 & 19.6 & 24.4 \\
\hline
\end{tabular}

Sources: Nigerian authorities and IMF staff estimates and projections.

CBN presents long-term liabilities in other items net. 
Table 3b. Nigeria: Monetary Survey, 2006-10

\begin{tabular}{|c|c|c|c|c|c|c|c|c|c|c|}
\hline & \multirow{2}{*}{$\begin{array}{c}2006 \\
\text { Dec. }\end{array}$} & \multirow{2}{*}{$\begin{array}{c}2007 \\
\text { Dec. }\end{array}$} & \multicolumn{4}{|c|}{2008} & \multicolumn{3}{|c|}{2009} & \multirow{3}{*}{$\begin{array}{l}2010 \\
\text { Dec. } \\
\text { Proj. }\end{array}$} \\
\hline & & & Mar. & Jun. & Sep. & Dec. & Mar. & Jun. & \multirow{2}{*}{$\begin{array}{l}\text { Dec. } \\
\text { Proj. }\end{array}$} & \\
\hline & Act. & & & & & & & & & \\
\hline & \multicolumn{10}{|c|}{ (Billions of naira) } \\
\hline Net foreign assets & 6,017 & 6,679 & 7,555 & 7,744 & 7,986 & 8,228 & 7,278 & 6,778 & 7,660 & 8,598 \\
\hline Central Bank of Nigeria (net) & 5,312 & 5,983 & 6,813 & 6,875 & 7,053 & 6,948 & 6,133 & 5,777 & 6,659 & 7,597 \\
\hline Commercial and merchant banks (net) & 704 & 696 & 743 & 870 & 934 & 1,280 & 1,144 & 1,001 & 1,001 & 1,001 \\
\hline Net domestic assets & $-1,989$ & -870 & 443 & 204 & 974 & 939 & 1,720 & 2,299 & 3,275 & 5,043 \\
\hline Net domestic credit & 1,019 & 3,275 & 3,898 & 4,615 & 4,805 & 5,345 & 5,719 & 6,612 & 8,024 & 9,698 \\
\hline Net claims on consolidated government & $-1,551$ & $-1,694$ & $-1,964$ & $-2,041$ & $-2,574$ & $-2,564$ & $-2,296$ & $-1,693$ & $-1,010$ & -992 \\
\hline Excess crude account & $-1,708$ & -268 & -373 & -400 & -672 & -884 & -622 & -294 & 69 & $-1,091$ \\
\hline Net claims on federal government & 169 & $-1,397$ & $-1,554$ & $-1,595$ & $-1,845$ & $-1,670$ & $-1,733$ & $-1,505$ & $-1,415$ & -192 \\
\hline States and local governments & 81 & 88 & 102 & 99 & 96 & 150 & 211 & 252 & 467 & 467 \\
\hline Statutory funds & -92 & -116 & -138 & -146 & -153 & -160 & -153 & -146 & -132 & -176 \\
\hline Claims on private sector & 2,531 & 4,740 & 5,726 & 6,551 & 7,216 & 7,657 & 7,709 & 7,977 & 8,705 & 10,362 \\
\hline Other net claims & 39 & 229 & 136 & 105 & 162 & 253 & 306 & 329 & 329 & 329 \\
\hline Other items (net) & $-3,008$ & $-4,145$ & $-3,456$ & $-4,411$ & $-3,831$ & $-4,406$ & $-3,999$ & $-4,313$ & $-4,749$ & $-4,655$ \\
\hline Broad money & 4,028 & 5,810 & 7,998 & 7,948 & 8,960 & 9,167 & 8,998 & 9,077 & 10,935 & 13,641 \\
\hline (y/y growth rate) & 53.4 & 44.2 & 66.7 & 55.4 & 58.0 & 57.8 & 12.5 & 14.2 & 19.3 & 24.8 \\
\hline Memorandum items: & \multicolumn{10}{|c|}{ (contribution to broad money growth, unless otherwise stated) } \\
\hline Net foreign assets & 72.5 & 16.4 & 32.1 & 31.5 & 23.5 & 26.6 & -3.5 & -12.2 & -6.2 & 8.6 \\
\hline Net domestic assets & -15.7 & 27.8 & 34.6 & 23.8 & 34.5 & 31.1 & 16.0 & 26.4 & 25.5 & 16.2 \\
\hline Net domestic credit & -14.8 & 56.0 & 49.5 & 43.5 & 48.3 & 35.6 & 22.8 & 25.1 & 29.2 & 15.3 \\
\hline Net credit to the consolidated government & -38.3 & -3.5 & -10.3 & -18.9 & -8.7 & -15.0 & -4.2 & 4.4 & 17.0 & 0.2 \\
\hline Claims on private sector & 22.6 & 54.8 & 57.7 & 61.5 & 54.8 & 50.2 & 24.8 & 17.9 & 11.4 & 15.2 \\
\hline Other items (net) & -0.9 & -28.2 & -14.9 & -19.6 & -13.9 & -4.5 & -6.8 & 1.2 & -3.7 & 0.9 \\
\hline Velocity (non-oil GDP/broad money) & 2.88 & 2.26 & $\ldots$ & $\ldots$ & $\ldots$ & 1.66 & $\ldots$ & $\ldots$ & 1.63 & 1.50 \\
\hline Gross international reserves (billions of US\$) & 41.8 & 51.3 & 59.8 & 57.1 & 59.3 & 53.0 & 48.2 & 42.5 & 41.6 & 44.1 \\
\hline
\end{tabular}

Sources: Nigerian authorities and IMF staff estimates and projections. 
Table 4. Nigeria: Financial Soundness Indicators, 2006-09

(In percent, unless otherwise indicated)

\begin{tabular}{|c|c|c|c|c|}
\hline & 2006 & 2007 & 2008 & $\begin{array}{r}2009 \\
\text { March }^{1 /}\end{array}$ \\
\hline \multicolumn{5}{|l|}{ Capital Adequacy } \\
\hline Regulatory capital to risk weighted assets & 22.6 & 21.0 & 21.9 & 21.5 \\
\hline Regulatory Tier I capital to risk-weighted assets & 21.8 & 20.2 & 21.5 & 21.2 \\
\hline Capital (net worth) to assets & 14.7 & 16.3 & 18.0 & 18.4 \\
\hline \multicolumn{5}{|l|}{ Asset quality and composition } \\
\hline Nonperforming loans to total gross loans & 8.8 & 8.4 & 6.3 & 6.6 \\
\hline Nonperforming loans net of loan-loss provision to capital & 21.3 & 22.7 & 16.8 & 5.5 \\
\hline \multicolumn{5}{|l|}{ Sectoral distribution of loans to total loans } \\
\hline Manufacturing & 16.9 & 11.1 & 13.1 & 12.9 \\
\hline Trade and Services & 22.0 & 15.3 & 16.6 & 22.4 \\
\hline Energy and Minerals & 10.1 & 10.7 & 11.4 & 11.1 \\
\hline Agriculture & 2.3 & 3.3 & 1.4 & 1.5 \\
\hline Construction and Property & 6.2 & 6.3 & 6.3 & 6.9 \\
\hline Government & 7.6 & 5.3 & 2.4 & 3.1 \\
\hline Other & 35.0 & 48.2 & 48.7 & 34.4 \\
\hline \multicolumn{5}{|l|}{ Earnings and profitability } \\
\hline Return on assets & 1.6 & 2.1 & 4.0 & 1.8 \\
\hline Return on equity & 10.4 & 13.1 & 22.0 & 10.0 \\
\hline Interest margin to gross income & 39.6 & 40.8 & 39.4 & 39.8 \\
\hline Noninterest expenses to gross income & 52.7 & 46.0 & 43.1 & 45.5 \\
\hline Personnel expenses to noninterest expenses & 42.7 & 44.2 & 42.1 & 44.3 \\
\hline Trading and fee income to total income & 33.3 & 30.0 & 12.9 & 13.1 \\
\hline \multicolumn{5}{|l|}{ Liquidity } \\
\hline Liquid asset to total assets & 32.5 & 32.1 & 28.1 & 20.4 \\
\hline Liquid assets to total deposits & 63.7 & 62.6 & 54.2 & 38.4 \\
\hline Liquid assets to short term liabilities & .. & .. & .. & 36.8 \\
\hline Customer deposit to total (non-interbank) loans & 73.7 & 85.8 & 117.4 & 116.3 \\
\hline Foreign currency denominated liabilities to total liabilities & 12.5 & 5.7 & 6.6 & 7.1 \\
\hline
\end{tabular}

Source: Nigerian authorities

${ }^{1 /}$ Reflects bank data available prior to the special audits of bank balance sheets by the central bank 
Table 5. Nigeria: Balance of Payments, 2006-10

(Billions of U.S. dollars, unless otherwise specified)

\begin{tabular}{|c|c|c|c|c|c|}
\hline & 2006 & 2007 & 2008 & \multirow{2}{*}{$\frac{2009}{\text { Est. }}$} & \multirow{2}{*}{$\begin{array}{r}2010 \\
\text { Proj. }\end{array}$} \\
\hline & \multicolumn{3}{|c|}{ Act. } & & \\
\hline Current account balance & 38.6 & 31.2 & 42.3 & 11.5 & 25.7 \\
\hline Trade balance & 34.8 & 36.2 & 47.2 & 19.0 & 34.3 \\
\hline Exports & 57.4 & 66.6 & 84.1 & 51.0 & 66.1 \\
\hline Oil/gas & 56.4 & 65.0 & 82.0 & 49.4 & 63.2 \\
\hline Other & 1.0 & 1.6 & 2.1 & 1.6 & 2.9 \\
\hline Imports & -22.6 & -30.4 & -36.9 & -32.0 & -31.8 \\
\hline Oil/gas & -5.1 & -5.6 & -8.2 & -4.6 & -6.0 \\
\hline Other & -17.6 & -24.8 & -28.7 & -27.4 & -25.8 \\
\hline Services (net) & -6.7 & -11.1 & -12.3 & -12.2 & -12.4 \\
\hline Receipts & 2.2 & 1.5 & 2.0 & 1.9 & 2.2 \\
\hline Payments & -8.9 & -12.6 & -14.2 & -14.1 & -14.6 \\
\hline Income (net) & -6.7 & -11.9 & -12.0 & -13.4 & -14.0 \\
\hline Of which: Interest due on public debt & -0.2 & -0.6 & -0.7 & -0.1 & -0.1 \\
\hline Transfers (net) $^{1}$ & 17.1 & 18.0 & 19.3 & 18.0 & 17.8 \\
\hline Capital and Financial account balance & -3.1 & 2.7 & -13.3 & 1.9 & 4.1 \\
\hline Capital Account (net) & 10.7 & 0.0 & 0.0 & 0.0 & 0.0 \\
\hline Financial Account (net) & -13.8 & 2.7 & -13.3 & 1.9 & 4.1 \\
\hline Direct Investement (net) & 4.9 & 5.6 & 3.6 & 4.4 & 3.3 \\
\hline Portfolio Investment (net) & 1.3 & 0.8 & -6.7 & -3.0 & 0.3 \\
\hline Other Investment (net) & -20.0 & -3.7 & -10.2 & 0.6 & 0.6 \\
\hline Errors and omissions & -21.4 & -24.8 & -27.3 & -27.3 & -27.3 \\
\hline Overall balance & 14.0 & 9.0 & 1.7 & -14.0 & 2.5 \\
\hline Net international reserves (increase -) ${ }^{2}$ & -14.0 & -9.0 & -1.7 & 11.3 & -2.5 \\
\hline \multicolumn{6}{|l|}{ Memorandum items: } \\
\hline Gross official reserves, end-of-period ${ }^{2}$ & 41.8 & 51.3 & 53.0 & 41.6 & 44.1 \\
\hline In months of next year's GS imports & 11.7 & 12.1 & 13.8 & 10.8 & 10.7 \\
\hline Current account (percent of GDP) & 26.5 & 18.8 & 20.4 & 6.9 & 13.8 \\
\hline GS exports (percent of GDP) & 41.0 & 41.0 & 41.6 & 32.0 & 36.8 \\
\hline GS imports (percent of GDP) & 21.7 & 25.9 & 24.7 & 27.9 & 25.0 \\
\hline External debt ${ }^{3}$ & 3.5 & 4.0 & 4.5 & 4.9 & 5.5 \\
\hline External debt (percent of GDP) $)^{3}$ & 2.4 & 2.4 & 2.2 & 3.0 & 3.0 \\
\hline External debt (percent of GS exports) ${ }^{3}$ & 5.9 & 5.9 & 5.2 & 9.3 & 8.1 \\
\hline External debt ${ }^{3,4}$ & 7.2 & 8.6 & 6.6 & 13.4 & 10.4 \\
\hline External debt service due (percent of GS exports) & 28.7 & 2.3 & 1.2 & 1.0 & 0.6 \\
\hline GDP (at market prices) & 145.4 & 165.9 & 207.1 & 165.4 & 185.8 \\
\hline
\end{tabular}

Sources: Nigerian authorities and IMF staff estimates and projections.

${ }^{1}$ Includes capital transfers.

${ }^{2}$ Includes $\$ 2.6$ billion in 2009 on account of the SDR allocation

${ }^{3}$ Nominal public sector short- and long-term debt, end of period.

${ }^{4}$ Percent of general government fiscal revenues. 
Table 6. Nigeria: Millennium Development Goals-Status at a Glance

\begin{tabular}{|c|c|c|c|c|c|}
\hline Goal & 1990 & 2000 & 2007 & $\begin{array}{l}\text { Target } \\
2015\end{array}$ & $\begin{array}{c}\text { Progress } \\
\text { Toward } \\
\text { Target } \\
\end{array}$ \\
\hline \multicolumn{6}{|l|}{ 1. Eradicate extreme poverty and hunger } \\
\hline Percentage of population living in relative poverty & 43 & 66 & $54^{2004}$ & 21 & Slow \\
\hline $\begin{array}{l}\text { Percentage of population living below minimum level of } \\
\text { dietary energy consumption }\end{array}$ & 13 & 13 & $\cdots$ & 5 & Good \\
\hline Percentage of underweight children (under 5) & 36 & 31 & 25 & 18 & Slow \\
\hline \multicolumn{6}{|l|}{ 2. Achieve universal education } \\
\hline Net enrolment ratio in primary education & 68 & 95 & 90 & 100 & Good \\
\hline $\begin{array}{l}\text { Proportion of pupils starting grade one who reach grade } \\
\text { five }\end{array}$ & 67 & 97 & 74 & 100 & Good \\
\hline Grade six completion rate & 58 & 77 & 68 & 100 & Good \\
\hline Literacy rate of $15-24$-year-olds & 71 & 64 & 81 & 100 & Good \\
\hline \multicolumn{6}{|l|}{ 3. Promote gender equality and empower women } \\
\hline $\begin{array}{l}\text { Ratio of girls to boys in primary education (girls per } 100 \\
\text { boys) }\end{array}$ & 76 & 78 & 94 & 100 & Good \\
\hline $\begin{array}{l}\text { Ratio of girls to boys in secondary education (girls } \\
\text { per100 boys) }\end{array}$ & 75 & 81 & 98 & 100 & Good \\
\hline $\begin{array}{l}\text { Ratio of girls to boys in tertiary education (girls per } 100 \\
\text { boys) }\end{array}$ & 46 & 66 & $\cdots$ & 100 & Good \\
\hline $\begin{array}{l}\text { Share of women in wage employment in the non- } \\
\text { agriculture sector (percent) }\end{array}$ & 66 & 79 & $\cdots$ & 100 & Lack of data \\
\hline $\begin{array}{l}\text { Proportion of seats held by women in national } \\
\text { parliament (percent) }\end{array}$ & 1 & 3 & 8 & 30 & Slow \\
\hline \multicolumn{6}{|l|}{ 4. Reduce child mortality } \\
\hline Infant mortality rate (per 1,000 live births) & 91 & 81 & 110 & 30 & Worsening \\
\hline Under-five mortality rate (per 1,000 live births) & 191 & 184 & 201 & 64 & Worsening \\
\hline $\begin{array}{l}\text { Percentage of 1-year-olds fully immunized against } \\
\text { measles }\end{array}$ & 46 & 33 & 60 & 100 & Good \\
\hline \multicolumn{6}{|l|}{ 5. Improve maternal health } \\
\hline Maternal mortality rate (per 100,000 live births) & $\ldots$ & $704^{1999}$ & $800^{2003}$ & 100 & Worsening \\
\hline Proportion of births attended by skilled health personnel & 45 & $42^{1999}$ & $36^{2003}$ & 100 & $\begin{array}{l}\text { Worsening/ } \\
\text { data } \\
\text { problem }\end{array}$ \\
\hline
\end{tabular}


Table 6. Nigeria: Millennium Development Goals-Status at a Glance (continued)

\begin{tabular}{|c|c|c|c|c|c|}
\hline Goal & 1990 & 2000 & 2007 & $\begin{array}{l}\text { Target } \\
2015\end{array}$ & $\begin{array}{l}\text { Progress } \\
\text { Toward } \\
\text { Target }\end{array}$ \\
\hline \multicolumn{6}{|l|}{ 6. Combat HIVIAIDS, malaria, and other diseases } \\
\hline HIV prevalence among pregnant women aged 15-24 & $\ldots$ & $5^{1999}$ & $4^{2005}$ & & Slow \\
\hline $\begin{array}{l}\text { Percentage of young people aged } 15-24 \text { reporting the } \\
\text { use of condoms during sexual intercourse with a non- } \\
\text { regular sexual partner }\end{array}$ & $\cdots$ & $\ldots$ & $\ldots$ & 100 & $\begin{array}{l}\text { Slow / Lack } \\
\text { of data }\end{array}$ \\
\hline Number of children (millions) orphaned by HIVIAIDS & $\cdots$ & $\ldots$ & $1.97^{2005}$ & & Lack of data \\
\hline Prevalence and death rates associated with malaria & $\ldots$ & $\ldots$ & $\ldots$ & & Lack of data \\
\hline $\begin{array}{l}\text { Prevalence and death rates associated with } \\
\text { tuberculosis }\end{array}$ & $\cdots$ & $\cdots$ & $\cdots$ & & Lack of data \\
\hline \multicolumn{6}{|l|}{ 7. Ensure environmental stability } \\
\hline Proportion of land area covered by forests & $\ldots$ & 15 & 13 & 20 & Worsening \\
\hline Proportion of gas flared & 68 & 53 & 34 & 0 & Slow \\
\hline $\begin{array}{l}\text { Proportion of total population with access to safe } \\
\text { drinking water }\end{array}$ & 54 & 54 & 49 & 100 & Worsening \\
\hline Proportion of people with access to secure tenure & $\ldots$ & 38 & 61 & 100 & Improving \\
\hline Carbon dioxide emissions (per capita) & $\ldots$ & 4799 & $2500^{2005}$ & $\ldots$ & Improving \\
\hline $\begin{array}{l}\text { Proportion of total population with access to basic } \\
\text { sanitation }\end{array}$ & 39 & 43 & 43 & 100 & Worsening \\
\hline Residential housing construction index (ACI) (Proxy) & $\ldots$ & 53 & $31^{2005}$ & & Worsening \\
\hline \multicolumn{6}{|l|}{ 8. Develop a global partnership for development } \\
\hline Per capita official development assistance to Nigeria (\$) & 3.0 & 1.47 & 81.67 & & Improving \\
\hline $\begin{array}{l}\text { Debt service as a percentage of exports of goods and } \\
\text { services }\end{array}$ & $\ldots$ & 9 & 1.2 & & Good \\
\hline Private sector Investment (\$ million) & 50 & 75 & 8100 & & Improving \\
\hline Telephone-density (per 1000 people) & 0.45 & 0.73 & 27.41 & & Good \\
\hline Personal computers (per 1000 people) & $\ldots$ & 6.38 & 6.74 & & Lack of data \\
\hline Internet access (percent) & 0.1 & 0.1 & 1.9 & & Slow \\
\hline
\end{tabular}

Source: Nigerian authorities, Millennium Development Goals Information Kit 2008. 


\section{APPENDIX - Assessment of the Exchange Rate Level for Nigeria}

Assessment of Nigeria's exchange rate is based on the IMF's CGER methodology, adapted for Nigeria's circumstances, using data as of mid-2009. One method suggests that the naira was overvalued by about 7 percent reflecting projected current account surpluses that are below the norm. Two methods-relating the value of the naira to its fundamental determinants, and comparing the projected current account surplus with the level needed to stabilize net foreign assets-suggest that the naira was undervalued by 13 percent and 7 percent. This assessment is broadly consistent with external stability.

\begin{tabular}{lccc}
\hline & $\begin{array}{c}\text { Macroeconomic } \\
\text { balance }^{2}\end{array}$ & $\begin{array}{c}\text { Equilibrium real } \\
\text { exchange rate }\end{array}$ & $\begin{array}{c}\text { External } \\
\text { sustainability }^{2}\end{array}$ \\
\hline CA norm & 7.4 & $\ldots$ & 4.0 \\
CA projection & 5.8 & $\ldots$ & 5.8 \\
CA gap & -1.6 & $\ldots$ & 1.8 \\
Elasticity & -0.239 & $\ldots$ & -0.239 \\
RER gap ${ }^{1}$ & $-\mathbf{7}$ & $+\mathbf{1 3}$ & $\mathbf{7}$ \\
\hline${ }^{1}$ Depreciation $(+=$ appreciation) needed to close gap between norm and projection. \\
${ }^{2}$ Current Account projection for 2013 includes $75 \%$ of errors and omissions.
\end{tabular}

1. Macroeconomic balance. Using coefficients relating current account balances to macroeconomic fundamentals, estimated from a sample of 13 oil- and gas-exporting countries (see IMF Country Report 2008/104), yields a current account norm for Nigeria of 7.4 percent of GDP. Nigeria's current account projections need to be adjusted to account for very large errors and omissions in the balance of payments. Assuming that three-quarters of errors and omissions reflect current account transactions, Nigeria's projected current account surplus is 5.8 percent of GDP in 2013, a little below the current account norm, suggesting that the exchange rate may be overvalued by 7 percent. This result should be treated with caution, however, given uncertainties about the estimated current account norm. Nigeria is less developed than most of the oil and gas exporters included in the sample used to construct the current account norm, so a lower norm may be appropriate for Nigeria given its pressing investment needs. This would be consistent with a smaller estimate of overvaluation or, possibly, undervaluation.

2. Equilibrium real effective exchange rate (REER). Estimation of a reduced-form relationship between the REER and certain macroeconomic fundamentals (relative productivity, oil price, and trade openness) suggests that the REER was about 13 percent below its estimated equilibrium level by mid-2009 (Figure A1.1). 
Figure Al.1. Nigeria: Estimated Equilibrium and Real Exchange Rates, 2000-2009

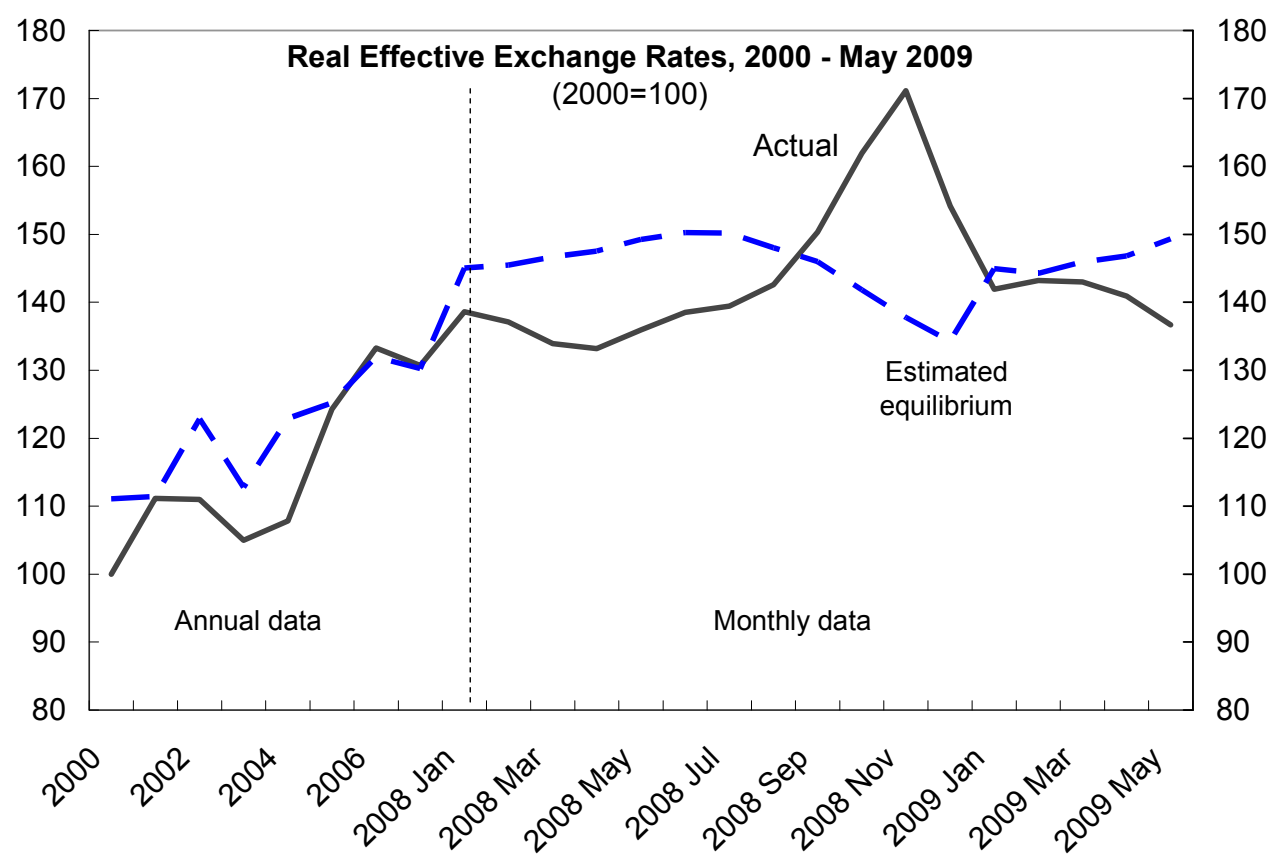

Sources: Nigerian authorities and IMF staff estimates.

3. External sustainability. Based on the medium-term projections for real growth and inflation, an external current account balance of 4 percent of GDP would stabilize net foreign assets at current levels over the medium term. This is somewhat lower than staff's projected medium-term current account balance of 5.8 percent of GDP which, adjusting for errors and omissions, suggests that the naira was undervalued by 7 percent. However, determining the appropriate target level for net foreign assets in Nigeria is not straightforward. As an oil producer seeking to preserve oil wealth for future generation, Nigeria should be seeking to accumulate financial assets via a higher current account surplus; as a low-income country with substantial investment needs, however, there is also a case for using its oil savings. 


\title{
INTERNATIONAL MONETARY FUND AND \\ INTERNATIONAL DEVELOPMENT ASSOCIATION
}

\section{NIGERIA \\ Joint IMF/World Bank Debt Sustainability Analysis Under the Debt Sustainability Framework for Low Income Countries}

\author{
Prepared by the staffs of the International Monetary Fund and \\ the International Development Association \\ Approved by Saul Lizondo and Dhaneshwar Ghura (IMF) \\ and Carlos Primo Braga and Kathie Krumm (IDA)
}

September 24, 2009

\begin{abstract}
Nigeria is at low risk of debt distress based on the joint Bank-IMF low-income country debt sustainability analysis (DSA) - as it was in the DSA published in February 2008. The debt outlook is robust both in the baseline scenario and in the case of standardized stress tests. ${ }^{\text {I }}$ For the two customized stress tests, all indicators deteriorate when compared to the baseline results, but remain within nearly all country-specific thresholds. ${ }^{2}$ Debt would become unsustainable if the primary balance remained unchanged from its anticipated 2009 level. The primary balance is expected to strengthen from this level, however, as oil prices recover. Debt would also become unsustainable in the event of a permanent shock to GDP growth. Given Nigeria's strong financial starting position, there would be time for fiscal policy to adjust to avoid an unsustainable build up of debt.
\end{abstract}

\section{A. Background}

1. Nigeria's external public debt is projected to total $\$ 4.5$ billion, or 2.2 percent of GDP, at end-2009. Approximately $\$ 4$ billion of the external debt stock is multilateral debt, with the remaining $\$ 1$ billion owed to bilateral creditors. Domestic public debt is projected to reach 12 percent of GDP at end-2009. The government also has substantial financial assets: deposits in the Excess Crude Account (ECA) at the central bank exceeded \$18 billion at end-2008 (almost 10 percent of GDP). A limitation of this DSA is that it applies only to debt contracted at the federal level. Data on sub-national borrowing are not available. While sub-national

\footnotetext{
${ }^{1}$ This DSA utilizes the updated Bank-Fund debt template for low-income countries. The previous DSA for Nigeria was undertaken as part of the 2007 Article IV consultation and published in February 2008.

2 The one exception concerns the threshold for the PV of debt-to-exports in certain years between 2019 and 2027. This threshold is temporarily breached in a scenario that assigns the errors and omissions.
} 
borrowing is limited, there are indications that State Governments are expanding their exposure to domestic creditors, underscoring the need for improved monitoring of subnational debt.

\section{B. Assumptions}

2. The assumptions contained in the baseline for 2009-29 are:

- $\quad$ Average growth of 5.6 percent over the period 2009-29 (somewhat below the average of 6 percent for 2006-2008) reflecting non-oil GDP growth of about 6.1 percent and growth in the oil and gas sector of 1.4 percent. $^{3}$ The latter assumes a pick up relative to 2008 as security-related disruptions ease and there is a gradual increase in the utilization of Nigeria's extensive gas reserves.

- $\quad$ Oil prices are assumed to be $\$ 60.5$ per barrel in 2009 , increasing to $\$ 80$ per barrel by 2012, and then remaining constant in real terms thereafter. ${ }^{4}$

- $\quad$ The consolidated government non-oil primary deficit (NOPD) averages around 25 percent of non-oil GDP over the medium term and declines gradually thereafter. This is consistent with the government's medium-term fiscal strategy and gives rise to an overall surplus and accumulation of deposits from 2012. It is assumed that the oilprice-based fiscal rule is applied, with a budget oil price assumed to be on average $\$ 5 \mathrm{a}$ barrel below the projected oil price. ${ }^{5}$

- $\quad$ Exports decline by 40 percent in 2009 because of lower oil prices. Export growth resumes in 2010; annual growth of 2 percent is achieved by 2016. The acceleration in export growth is driven largely by developments in the oil and gas sector. Imports decline by nearly 12 percent in 2009 before returning to an annual growth rate of 6 percent starting in 2010. After recording a deficit in 2009, the balance of payments moves into surplus over the medium term but goes back into deficit after 2026 as import growth, primarily non-oil imports, outstrips that of exports. It is important to note that there is a break in the balance of payments data series between 2005 and 2006, owing to the adoption of the central bank balance of payments data commencing at that time. This results in a significant increase in errors and omissions and a much higher figure for net remittances. The increase in errors and omissions is taken into

\footnotetext{
${ }^{3}$ This is less than the average growth rate assumption of 7.1 percent used in the previous DSA. The projections used in that DSA proved accurate for 2007 but over-optimistic for 2008 ( 9 percent vs. an outturn of 6 percent).

${ }^{4}$ Based on WEO oil price projections as of June 12, 2009

${ }^{5}$ The government is assumed to establish a long-term sustainable fiscal position. This is calculated on the basis of a constant consumption of oil wealth in real terms and implies a decline in the consumption of oil wealth (the non-oil deficit) as a percent of non-oil GDP over time. Oil reserves are sufficient to sustain oil production at or above current levels throughout the projection period.
} 
account in a country-specific stress test. The break in the data affects the calculations of historical averages.

- $\quad$ Future official financing flows are small. The only significant disbursements after 2013 are from IDA, which explains the observed increase in the grant element of new borrowing in figure $1 \mathrm{a}$.

\section{External Sustainability ${ }^{6}$}

3. In the baseline scenario (Table 1a and Figure 1), the nominal external debt burden is projected to be broadly unchanged throughout the projection period. The debt-service-toexport ratio falls from 1 percent in 2009 to an average of 0.5 percent thereafter. The present value (PV) of debt-to-GDP ratio and the nominal external-debt-to-GDP ratio average less than 2 percent over the period.

\section{Alternative Scenarios and Stress Tests}

4. Standardized stress tests (Table $1 \mathrm{~b}$ and Figure 1) show that the NPV of the debt-toGDP ratio is not likely to exceed 16 percent of GDP over the projection period. In the most extreme standardized stress test for the PV of debt-to-exports ratio, holding export value growth at the historical average minus one standard deviation in 2010-2011 causes the PV of debt to increase to over 40 percent of exports for 2011-2013; this is still below the indicative debt burden threshold.

5. Two country-specific scenarios were examined.

- $\quad$ The first recognizes the large value for errors and omissions in the balance of payments and that this may reflect an underestimation of current account debit transactions. The trade balance was recalculated assuming that three-quarters of the projected errors and omissions for 2010-2029 are attributed to the trade balance. In this scenario, all indicators are weaker than in the baseline results. A temporary breach of the threshold for the PV of debt-to-export ratio occurs in some years between 2019 and 2027. The scenario assumes no policy response from the authorities and involves an artificial adjustment of the denominator in the calculation of the debt-to-exports ratio. This does not change the overall assessment for Nigeria of a robust outlook.

- $\quad$ The second scenario illustrates the impact on the external accounts and debt dynamics of a prolonged oil price shock. The impact of the oil price shock on the external

\footnotetext{
${ }^{6}$ The low-income country debt sustainability framework (DSF) provides a methodology for assessing external debt sustainability guided by indicative, country-specific, debt burden thresholds based on the relative strength of a country's policies and institutions. Given Nigeria's rating of 3.26 (medium performer), which is the three-year average of the World Bank's Country Policy and Institutional Assessment (CPIA), the country-specific thresholds are an NPV of debt to GDP of 40 percent, an NPV of debt-to-exports of 150 percent, and a debt-service-toexports ratio of 20 percent.
} 
accounts is calibrated as one standard deviation of Brent crude prices over the period 1970-2009. This reduces future oil prices by $\$ 19$ per barrel. All indicators worsen in this scenario but remain within country-specific thresholds. The PV of the debt-toexport ratio reaches close to 50 percent in 2019-still some way from the debt burden threshold of 150 percent.

\section{Fiscal Sustainability}

6. In the baseline scenario (Table 2a and Figure 2), consolidated government deposits continue to accumulate at the central bank, reaching almost $\$ 70$ billion by 2030 . The accumulation of deposits will begin to slow beyond 2030 in line with the eventual decline in oil production. Recognizing the accumulation of such significant levels of government deposits, and the low level of gross debt, the fiscal debt sustainability exercise for Nigeria utilizes a concept of net debt, defined as gross consolidated government debt (external and domestic) less gross consolidated government assets (specifically, the balance in the ECA). ${ }^{7}$ With these government assets included, net debt is projected in the baseline scenario to be negative from 2017.

\section{Alternative Scenarios and Stress Tests}

7. The standardized stress tests underscore the need for fiscal policy to adjust to the economic environment. In particular, debt soon becomes unsustainable if the primary balance is unchanged from the 2009 level — an unusual year, given the sharp drop in oil prices from 2008 and the need to use fiscal policy to cushion the impact on Nigeria of the global recession. Once oil prices stabilize and economic growth recovers as assumed in the baseline, fiscal policy will need to adjust accordingly. Similarly, a permanent shock to GDP growth would necessitate an eventual fiscal policy adjustment, or the debt ratios would escalate beyond 2020 (Table $2 \mathrm{~b}$ and Figure 2).

\section{E. Conclusion}

8. Nigeria is at low risk of external debt distress. While large negative errors and omissions in the balance of payments warrant a degree of caution in interpreting the result of the DSA, in the baseline scenario and in the standardized stress tests, Nigeria's debt outlook remains robust throughout the projection period. Fiscal policy would need to adjust in order to maintain debt sustainability in the event of a sustained reduction in oil prices or a permanent shock to GDP growth. However, Nigeria's strong financial starting position would provide ample time for policy to adjust. As anticipated in the baseline, the primary balance will also need to strengthen from its 2009 level as oil prices economic growth recover. There also appears to be a low risk of public debt distress although data at the subnational level is needed to provide a more thorough assessment.

\footnotetext{
${ }^{7}$ For illustrative purposes, Figure 1 also traces the evolution of gross debt in the baseline scenario.
} 
Figure 1. Nigeria: Indicators of Public and Publicly Guaranteed External Debt under Alternatives Scenarios, 2009-2029 1/
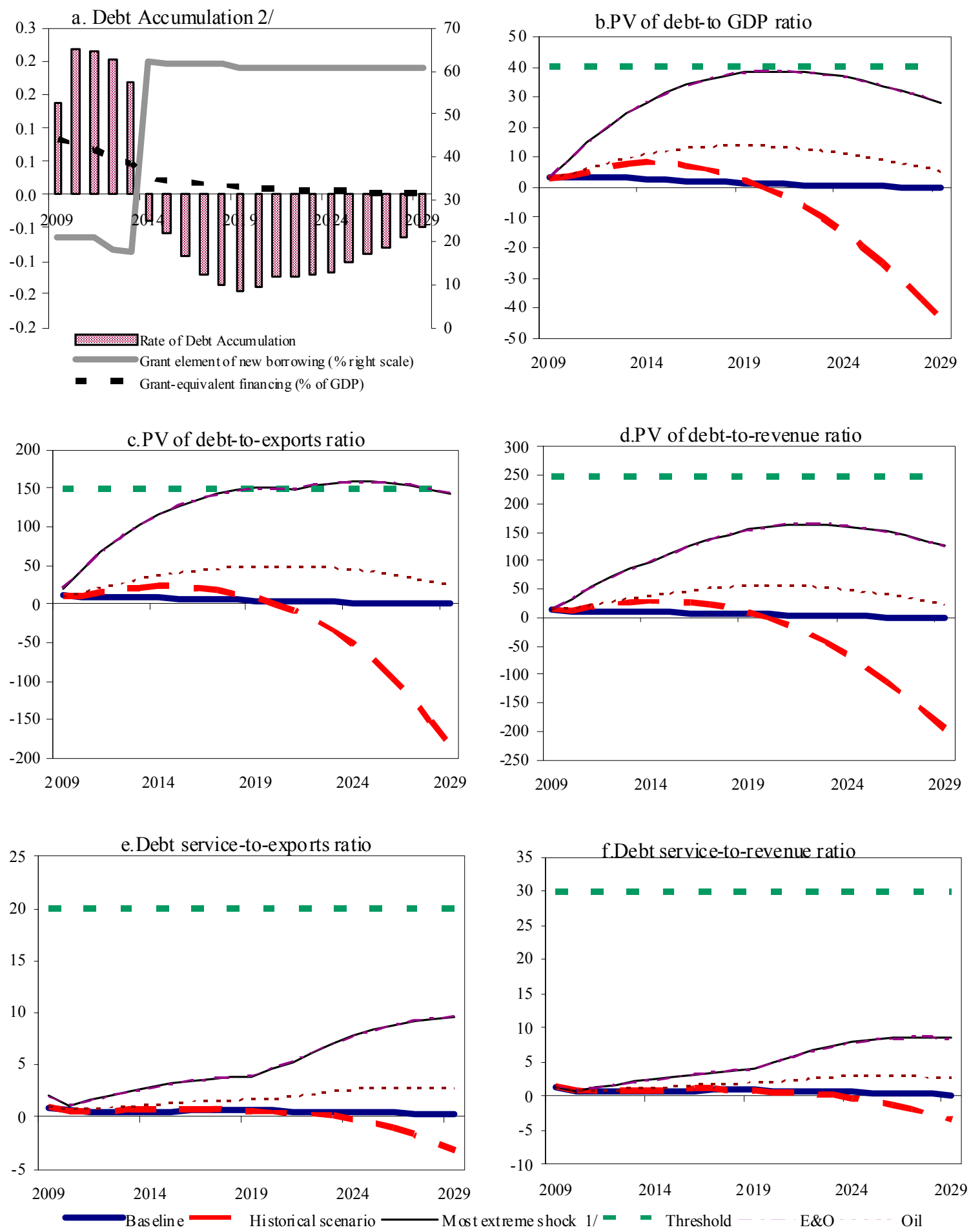

Source: Staff projections and simulations.

1/ The most extreme stress test is the test that yields the highest ratio in 2019. In all figures it corresponds to the shock to Errors and Omis sions.

$\angle /$ Ine large jump in the \% or grant borrowing result s trom naving just IDA disbursements projected from 2014 
Table 1a: External Debt Sustainability Framework, Baseline Scenario, 2006-2029 1/

(In percent of GDP, unless otherwise indicated)

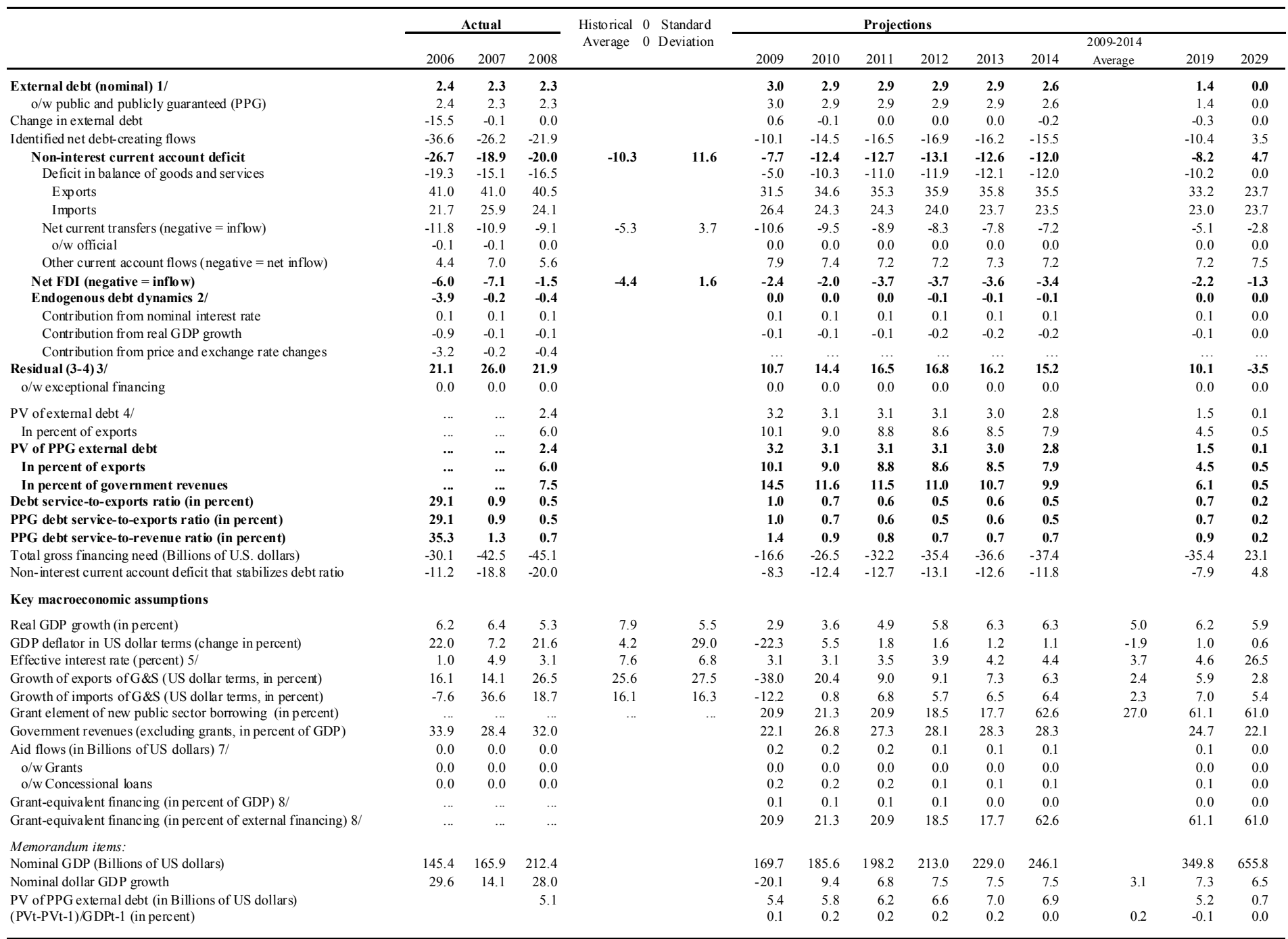

Source: Staff simulations.

1/ Includes both public and private sector external debt.

2/ Derived as $[\mathrm{r}-\mathrm{g}-\mathrm{r}(1+\mathrm{g})](1+\mathrm{g}+\mathrm{r}+\mathrm{gr})$ times previous period debt ratio, with $\mathrm{r}=$ nominal interest rate; $\mathrm{g}=$ real GDP growth rate, and $\mathrm{r}=$ growth rate of GDP deflator in U.S. dollar terms.

3/ Includes exceptional financing (i.e., changes in arrears and debt relief); changes in gross foreign assets; and valuation adjustments. For projections also includes contribution from price and exchange rate changes.

4/ Assumes that PV of private sector debt is equivalent to its face value.

6/ Historical aerest past 10 years, subject to data availabili

7/ Defined as grants, concessional loans and debt relief.

8/ Grant-equivalent financing includes grants provided directly to the government and through new borrowing (difference between the face value and the PV of new debt). 
Table 1b.Nigeria: Sensitivity Analysis for Key Indicators of Public and Publicly Guaranteed External Debt, 2009-2029 (In percent)

Projections

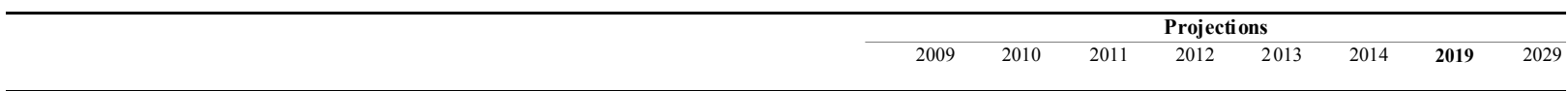

PV of debt-to GDP ratio

Baseline

A. Alternative Scenarios

A1. Key variables at their historical averages in 2009-2029 1/

A2. New public sector loans on less favorable terms in 2009-2029

A3. Alternative Scenario : Errors and Omissions

A4. Alternative Scenario :Oil Shock

B. Bound Tests

B1. Real GDP growth at historical average minus one standard deviation in 2010-2011

B2. Export value growth at historical average minus one standard deviation in 2010-2011 3/

B3. US dollar GDP deflator at historical average minus one standard deviation in 2010-2011

B4. Net non-debt creating flows at historical average minus one standard deviation in 2010-2011 4/

B5. Combination of B1-B4 using one-half standard deviation shocks

B6. One-time 30 percent nominal depreciation relative to the baseline in 20105/

PV of debt-to-exports ratio

\section{Baseline}

\section{A. Alternative Scenario}

A1. Key variables at their historical averages in 2009-2029 1/

A2. New public sector loans on less favorable terms in 2009-20292

A3. Alternative Scenario :Errors and Omissions

A4. Alternative Scenario :Oil Shock

B. Bound Tests

B1. Real GDP growth at historical average minus one standard deviation in 2010-2011

B2. Export value growth at historical average minus one standard deviation in 2010-2011 3/

B3. US dollar GDP deflator at historical average minus one standard deviation in 2010-2011

B4. Net non-debt creating flows at historical average minus one standard deviation in 2010-2011 4/

B5. Combination of B1-B4 using one-half standard deviation shocks

B6. One-time 30 percent nominal depreciation relative to the baseline in 20105 /

PV of debt-to-revenue ratio

Baseline

A. Alternative Scenarios

A1. Key variables at their historical averages in 2009-2029 1/

A2. New public sector loans on less favorable terms in 2009-20292

A3. Alternative Scenario : Errors and Omissions

A4. Alternative Scenario :Oil Shock

B. Bound Tests

B1. Real GDP growth at historical average minus one standard deviation in 2010-2011

B2. Export value growth at historical average minus one standard deviation in 2010-2011 3/

B3. US dollar GDP deflator at historical average minus one standard deviation in 2010-2011

B4. Net non-debt creating flows at historical average minus one standard deviation in 2010-2011 4/

B5. Combination of B1-B4 using one-half standard deviation shocks

B6. One-time 30 percent nominal depreciation relative to the baseline in 20105 /
1

12

11

11

11

1

6

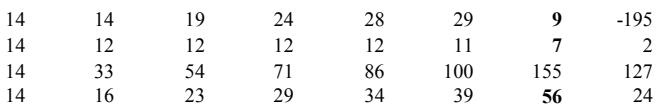

1

$\begin{array}{rrrrrrrr}14 & 12 & 12 & 11 & 11 & 10 & \mathbf{6} & 0 \\ 14 & 24 & 42 & 40 & 38 & 36 & \mathbf{3 2} & 14 \\ 14 & 16 & 22 & 21 & 20 & 19 & \mathbf{1 1} & 1 \\ 14 & 26 & 41 & 39 & 38 & 36 & \mathbf{3 2} & 14 \\ 14 & 32 & 58 & 55 & 52 & 50 & \mathbf{4 4} & 19 \\ 14 & 16 & 16 & 15 & 15 & 14 & \mathbf{8} & 1\end{array}$


Table 1b.Nigeria: Sensitivity Analysis for Key Indicators of Public and Publicly Guaranteed External Debt, 2009-2029 (continued)

(In percent)

Debt service-to-exports ratio

\section{Baseline}

A. Alternative Scenarios

A1. Key variables at their historical averages in 2009-2029 1/

A2. New public sector loans on less favorable terms in 2009-2029 2

A3. Alternative Scenario :Errors and Omissions

A4. Alternative Scenario :Oil Shock

B. Bound Tests

B1. Real GDP growth at historical average minus one standard deviation in 2010-2011

B2. Export value growth at historical average minus one standard deviation in 2010-2011 3/

B3. US dollar GDP deflator at historical average minus one standard deviation in 2010-2011

B4. Net non-debt creating flows at historical average minus one standard deviation in 2010-2011 4

B5. Combination of B1-B4 using one-half standard deviation shocks

B6. One-time 30 percent nominal depreciation relative to the baseline in 2010 5/
1

$\begin{array}{rrrrrrrr}1 & 1 & 1 & 1 & 1 & 1 & \mathbf{1} & -3 \\ 1 & 1 & 1 & 1 & 1 & 1 & \mathbf{1} & 0 \\ 2 & 1 & 2 & 2 & 2 & 3 & \mathbf{4} & 10 \\ 1 & 1 & 1 & 1 & 1 & 1 & \mathbf{2} & 3\end{array}$

Debt service-to-revenue ratio

Baseline

\section{A. Alternative Scenarios}

A1. Key variables at their historical averages in 2009-2029 1/

A2. New public sector loans on less favorable terms in 2009-2029 2

A3. Alternative Scenario : Errors and Omissions

A4. Alternative Scenario :Oil Shock

\section{B. Bound Tests}

B1. Real GDP growth at historical average minus one standard deviation in 2010-2011 B2. Export value growth at historical average minus one standard deviation in 2010-2011 3

B3. US dollar GDP deflator at historical average minus one standard deviation in 2010-2011

B4. Net non-debt creating flows at historical average minus one standard deviation in 2010-2011 4/

B5. Combination of B1-B4 using one-half standard deviation shocks

B6. One-time 30 percent nominal depreciation relative to the baseline in 20105 /

Memorandum item

Grant element assumed on residual financing (i.e., financing required above baseline) 6

$\begin{array}{llllllll}1 & 1 & 1 & 1 & 1 & 1 & \mathbf{1} & 0 \\ 1 & 1 & 1 & 1 & 1 & 1 & \mathbf{1} & 2 \\ 1 & 1 & 1 & 1 & 1 & 1 & \mathbf{1} & 0 \\ 1 & 1 & 1 & 1 & 1 & 1 & \mathbf{1} & 1 \\ 1 & 1 & 1 & 1 & 1 & 1 & \mathbf{1} & 1 \\ 1 & 1 & 1 & 1 & 1 & 1 & \mathbf{1} & 0\end{array}$

Source: Staff projections and simulations.

1/ Variables include real GDP growth, growth of GDP deflator (in U.S. dollar terms), non-interest current account in percent of GDP, and non-debt creating flows.

2/ Assumes that the interest rate on new borrowing is by 2 percentage points higher than in the baseline., while grace and maturity periods are the same as in the baseline.

3/ Exports values are assumed to remain permanently at the lower level, but the current account as a share of GDP is assumed to return to its baseline level after the shock (implicitly assuming an offsetting adjustment in import levels).

4/ Includes official and private transfers and FDI

5/ Depreciation is defined as percentage decline in dollar/local currency rate, such that it never exceeds 100 percent.

6/ Applies to all stress scenarios except for A2 (less favorable financing) in which the terms on all new financing are as specified in footnote 2. 
Figure 2.Nigeria: Indicators of Public Debt Under Alternative Scenarios, 2009-2029 1/

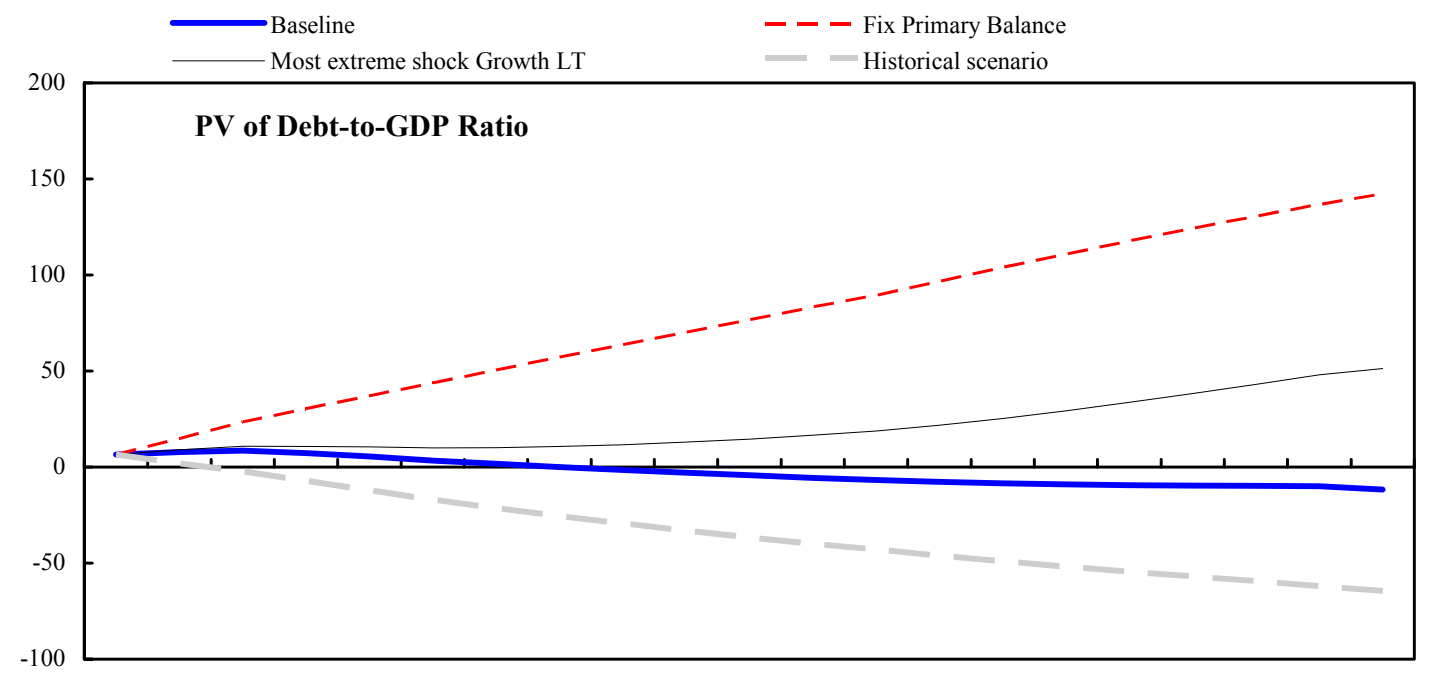

200920102011201220132014201520162017201820192020202120222023202420252026202720282029

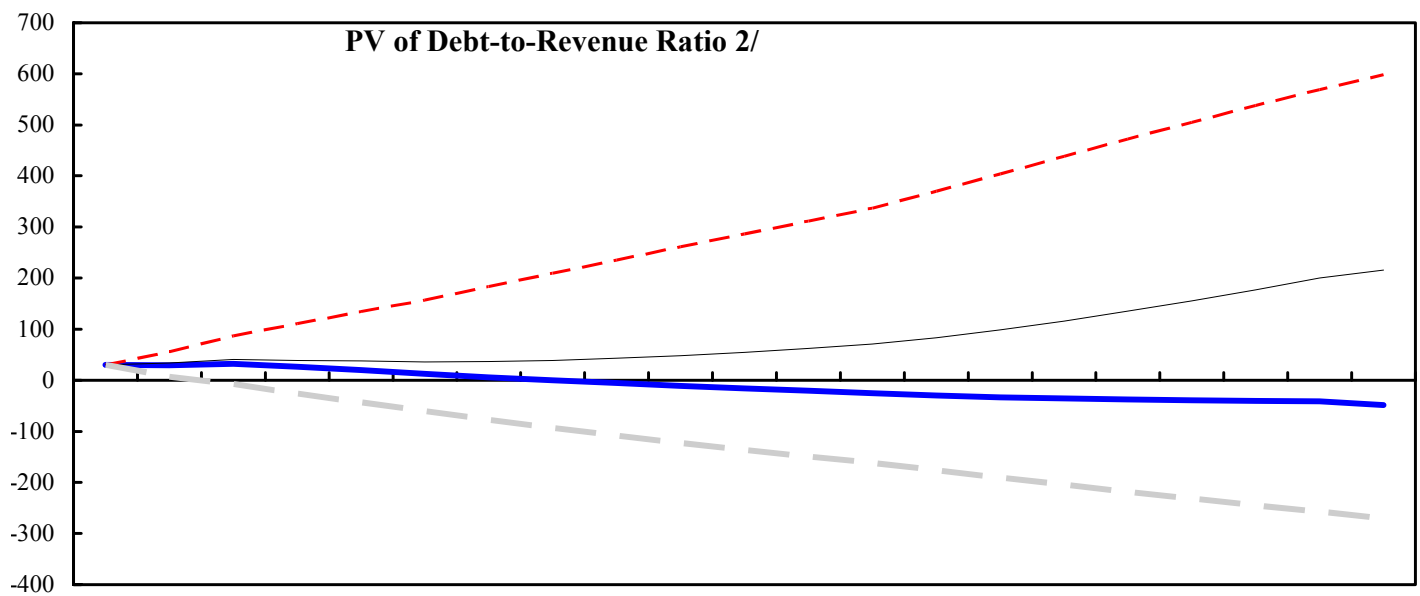

200920102011201220132014201520162017201820192020202120222023202420252026202720282029

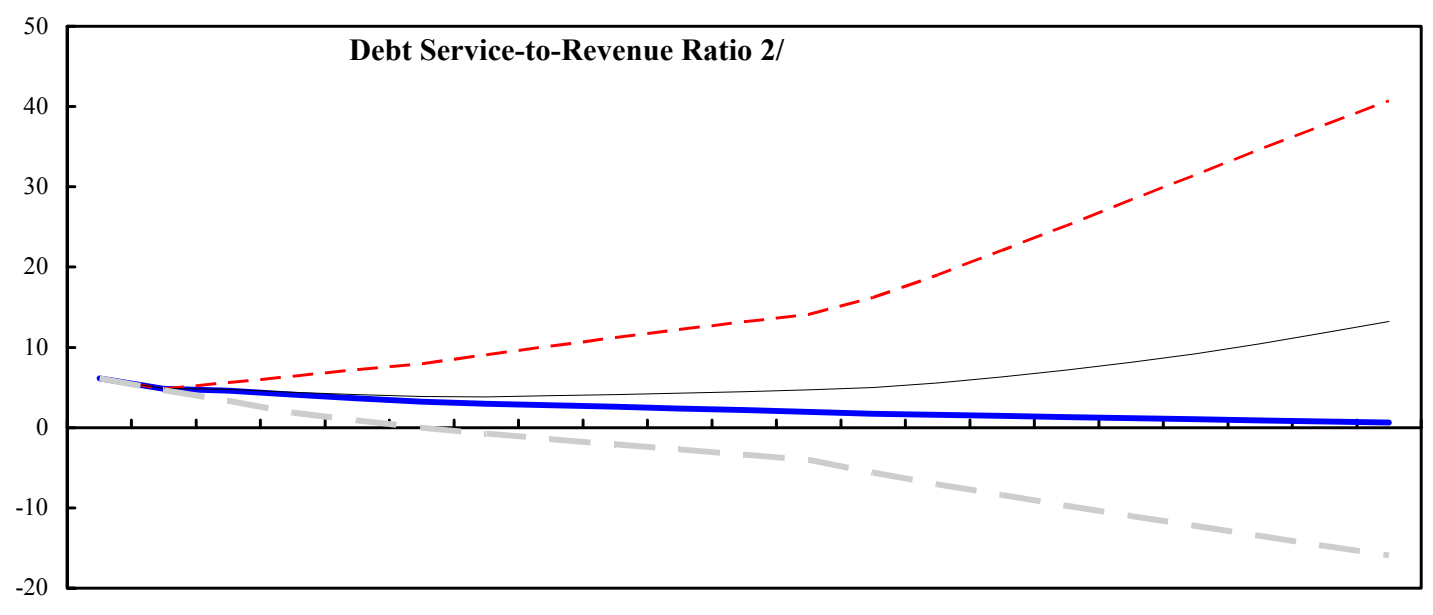

200920102011201220132014201520162017201820192020202120222023202420252026202720282029

Sources: Country authorities; and Fund staff estimates and projections.

1/ The most extreme stress test is the test that yields the highest ratio in 2019.

$2 /$ Revenues are defined inclusive of grants. 
Table 2a.Nigeria: Public Sector Debt Sustainability Framework, Baseline Scenario, 2006-2029

(In percent of GDP, unless otherwise indicated)

\begin{tabular}{|c|c|c|c|c|c|c|c|c|c|c|c|c|c|c|}
\hline & \multicolumn{3}{|c|}{ Actual } & \multirow[b]{2}{*}{ Average } & \multirow[b]{2}{*}{$\begin{array}{c}\text { Standard } \\
\text { Deviation }\end{array}$} & \multicolumn{4}{|l|}{ Estimate } & \multicolumn{2}{|c|}{ Projections } & \multirow[b]{2}{*}{$\begin{array}{l}2009-14 \\
\text { Average }\end{array}$} & \multirow[b]{2}{*}{2019} & \multirow[b]{2}{*}{2029} \\
\hline & 2006 & 2007 & 2008 & & & 2009 & 2010 & 2011 & 2012 & 2013 & 2014 & & & \\
\hline Public sector debt 1 / & -6.2 & -1.9 & -0.5 & & & 6.8 & 8.1 & 8.8 & 7.4 & 5.8 & 3.7 & & -4.1 & -11.6 \\
\hline $\mathrm{o} / \mathrm{w}$ foreign-currency denominated & 2.4 & 2.3 & 2.3 & & & 3.0 & 2.9 & 2.9 & 2.9 & 2.9 & 2.6 & & 1.4 & 0.0 \\
\hline Change in public sector debt & -26.3 & 4.4 & 1.3 & & & 7.3 & 1.3 & 0.7 & -1.4 & -1.6 & -2.2 & & -1.4 & -1.7 \\
\hline Identified debt-creating flows & -19.5 & -0.1 & -4.3 & & & 8.3 & 0.4 & -0.7 & -1.9 & -2.0 & -2.6 & & -2.0 & -2.8 \\
\hline Primary deficit & -8.0 & 0.1 & -4.6 & -6.2 & 4.6 & 8.0 & 0.9 & -0.4 & -1.5 & -1.7 & -2.4 & 0.5 & -2.2 & -3.0 \\
\hline Revenue and grants & 33.9 & 28.4 & 32.0 & & & 21.3 & 26.6 & 27.0 & 27.5 & 27.7 & 27.9 & & 26.8 & 23.8 \\
\hline of which: grants & 0.0 & 0.0 & 0.0 & & & 0.0 & 0.0 & 0.0 & 0.0 & 0.0 & 0.0 & & 0.0 & 0.0 \\
\hline Primary (noninterest) expenditure & 25.9 & 28.5 & 27.4 & & & 29.3 & 27.4 & 26.6 & 26.0 & 26.0 & 25.5 & & 24.6 & 20.8 \\
\hline Automatic debt dynamics & -4.0 & -0.2 & 0.3 & & & 0.3 & -0.5 & -0.3 & -0.4 & -0.3 & -0.2 & & 0.1 & 0.3 \\
\hline Contribution from interest rate/growth differential & -3.9 & 0.0 & 0.0 & & & -0.2 & -0.7 & -0.5 & -0.6 & -0.5 & -0.4 & & 0.0 & 0.3 \\
\hline of which: contribution from average real interest rate & -2.7 & -0.4 & -0.1 & & & -0.2 & -0.4 & -0.1 & -0.1 & 0.0 & 0.0 & & -0.1 & -0.3 \\
\hline of which: contribution from real GDP growth & -1.2 & 0.4 & 0.1 & & & 0.0 & -0.2 & -0.4 & -0.5 & -0.4 & -0.3 & & 0.2 & 0.6 \\
\hline Contribution from real exchange rate depreciation & -0.1 & -0.2 & 0.2 & & & 0.5 & 0.2 & 0.2 & 0.2 & 0.2 & 0.2 & & $\ldots$ & ... \\
\hline Other identified debt-creating flows & -7.5 & 0.0 & 0.0 & & & 0.0 & 0.0 & 0.0 & 0.0 & 0.0 & 0.0 & & 0.0 & 0.0 \\
\hline Privatization receipts (negative) & 0.0 & 0.0 & 0.0 & & & 0.0 & 0.0 & 0.0 & 0.0 & 0.0 & 0.0 & & 0.0 & 0.0 \\
\hline Recognition of implicit or contingent liabilities & 0.0 & 0.0 & 0.0 & & & 0.0 & 0.0 & 0.0 & 0.0 & 0.0 & 0.0 & & 0.0 & 0.0 \\
\hline Debt relief (HIPC and other) & -7.5 & 0.0 & 0.0 & & & 0.0 & 0.0 & 0.0 & 0.0 & 0.0 & 0.0 & & 0.0 & 0.0 \\
\hline Other (specify, e.g. bank recapitalization) & 0.0 & 0.0 & 0.0 & & & 0.0 & 0.0 & 0.0 & 0.0 & 0.0 & 0.0 & & 0.0 & 0.0 \\
\hline Residual, including asset changes & -6.8 & 4.5 & 5.6 & & & -1.0 & 0.9 & 1.4 & 0.5 & 0.4 & 0.4 & & 0.7 & 1.1 \\
\hline \multicolumn{15}{|l|}{ Other Sustainability Indicators } \\
\hline PV of public sector debt & -8.7 & -4.2 & -0.2 & & & 7.2 & 8.5 & 9.1 & 7.7 & 6.1 & 3.9 & & -3.9 & -11.5 \\
\hline $\mathrm{o} / \mathrm{w}$ foreign-currency denominated & 0.0 & 0.0 & 2.7 & & & 3.4 & 3.2 & 3.2 & 3.2 & 3.1 & 2.9 & & 1.6 & 0.1 \\
\hline $\mathrm{o} / \mathrm{w}$ external & $\ldots$ & & 2.7 & & & 3.4 & 3.2 & 3.2 & 3.2 & 3.1 & 2.9 & & 1.6 & 0.1 \\
\hline PV of contingent liabilities (not included in public sector debt) & $\ldots$ & $\ldots$ & & & & $\ldots$ & $\ldots$ & $\ldots$ & $\ldots$ & $\ldots$ & $\ldots$ & & $\ldots$ & $\ldots$ \\
\hline Gross financing need $2 /$ & 7.5 & 4.1 & -0.6 & & & 12.2 & 5.4 & 4.2 & 2.7 & 2.0 & 0.8 & & -0.4 & -2.6 \\
\hline $\mathrm{PV}$ of public sector debt-to-revenue and grants ratio (in percent) & -25.6 & -14.7 & -0.6 & & & 33.6 & 31.8 & 33.8 & 28.1 & 21.9 & 14.0 & & -14.6 & -48.3 \\
\hline $\mathrm{PV}$ of public sector debt-to-revenue ratio (in percent) & -25.6 & -14.7 & -0.6 & & & 33.6 & 31.8 & 33.8 & 28.1 & 21.9 & 14.0 & & -14.6 & -48.3 \\
\hline o/w external $3 /$ & & $\ldots$ & 8.3 & & & 15.8 & 12.2 & 12.0 & 11.7 & 11.3 & 10.3 & & 5.8 & 0.5 \\
\hline Debt service-to-revenue and grants ratio (in percent) $4 /$ & 37.9 & 4.5 & 3.6 & & & 6.2 & 5.1 & 4.8 & 4.3 & 3.8 & 3.4 & & 2.2 & 0.7 \\
\hline Debt service-to-revenue ratio (in percent) 4 / & 37.9 & 4.5 & 3.6 & & & 6.2 & 5.1 & 4.8 & 4.3 & 3.8 & 3.4 & & 2.2 & 0.7 \\
\hline Primary deficit that stabilizes the debt-to-GDP ratio & 18.3 & -4.3 & -5.9 & & & 0.7 & -0.4 & -1.1 & -0.1 & -0.1 & -0.2 & & -0.8 & -1.3 \\
\hline \multicolumn{15}{|l|}{ Key macroeconomic and fiscal assumptions } \\
\hline Real GDP growth (in percent) & 6.2 & 6.4 & 5.3 & 7.9 & 5.5 & 2.9 & 3.6 & 4.9 & 5.8 & 6.3 & 6.3 & 5.0 & 6.2 & 5.9 \\
\hline Average nominal interest rate on forex debt (in percent) & 1.2 & 6.0 & 4.0 & 7.9 & 6.7 & 4.1 & 4.0 & 4.3 & 4.5 & 4.8 & 4.9 & 4.4 & 5.0 & 30.4 \\
\hline Average real interest rate on domestic debt (in percent) & -7.4 & 5.2 & -3.6 & -0.7 & 10.0 & 11.7 & -3.9 & 0.4 & 0.7 & 1.5 & 1.8 & 2.0 & 2.1 & 3.2 \\
\hline Real exchange rate depreciation (in percent,+ indicates depreciation) & -0.6 & -8.0 & 11.3 & 2.5 & 7.3 & 21.9 & $\ldots$ & $\ldots$ & $\ldots$ & $\ldots$ & $\ldots$ & $\ldots$ & $\ldots$ & $\ldots$ \\
\hline Inflation rate (GDP deflator, in percent) & 19.5 & 4.8 & 14.7 & 15.9 & 10.4 & -0.6 & 15.7 & 10.2 & 9.6 & 8.8 & 8.5 & 8.7 & 8.4 & 7.9 \\
\hline Growth of real primary spending (deflated by GDP deflator, in percent) & 0.1 & 0.2 & 0.0 & 0.1 & 0.3 & 0.1 & 0.0 & 0.0 & 0.0 & 0.1 & 0.0 & 0.0 & 0.1 & 0.0 \\
\hline Grant element of new external borrowing (in percent) & $\ldots$ & & & ... & ... & 20.9 & 21.3 & 20.9 & 18.5 & 17.7 & 62.6 & 27.0 & 61.1 & 61.0 \\
\hline
\end{tabular}

Sources: Country authorities; and Fund staff estimates and projections.

2/ Gross financing need is defined as the primary deficit plus debt service plus the stock of short-term debt at the end of the last period.

3/ Revenues excluding grants.

4/ Debt service is defined as the sum of interest and amortization of medium and long-term debt.

5/ Historical averages and standard deviations are generally derived over the past 10 years, subject to data availability. 
Table 2b.Nigeria: Sensitivity Analysis for Key Indicators of Public Debt 2009-2029

\begin{tabular}{|c|c|c|c|c|c|c|c|c|}
\hline & \multicolumn{8}{|c|}{ Projections } \\
\hline & 2009 & 2010 & 2011 & 2012 & 2013 & 2014 & 2019 & 2029 \\
\hline \multicolumn{9}{|c|}{ PV of Debt-to-GDP Ratio } \\
\hline Baseline & 7 & 8 & 9 & 8 & 6 & 4 & -4 & -11 \\
\hline \multicolumn{9}{|l|}{ A. Alternative scenarios } \\
\hline A1. Real GDP growth and primary balance are at historical averages & 7 & 3 & -2 & -7 & -12 & -16 & -36 & -64 \\
\hline A2. Primary balance is unchanged from 2009 & 7 & 16 & 24 & 31 & 38 & 44 & 77 & 143 \\
\hline A3. Permanently lower GDP growth 1 / & 7 & 10 & 11 & 11 & 11 & 10 & 15 & 51 \\
\hline \multicolumn{9}{|l|}{ B. Bound tests } \\
\hline B1. Real GDP growth is at historical average minus one standard deviations in $2010-2011$ & 7 & 10 & 12 & 12 & 11 & 10 & 7 & 9 \\
\hline B2. Primary balance is at historical average minus one standard deviations in $2010-2011$ & 7 & 7 & 7 & 6 & 5 & 3 & -3 & -6 \\
\hline B3. Combination of B1-B2 using one half standard deviation shocks & 7 & 5 & 3 & 1 & 0 & -2 & -10 & -15 \\
\hline B4. One-time 30 percent real depreciation in 2010 & 7 & 11 & 12 & 11 & 9 & 7 & 1 & -3 \\
\hline B5. 10 percent of GDP increase in other debt-creating flows in 2010 & 7 & 18 & 19 & 18 & 16 & 14 & 7 & 1 \\
\hline
\end{tabular}

PV of Debt-to-Revenue Ratio 2/

Baseline

\section{A. Alternative scenarios}

A1. Real GDP growth and primary balance are at historical averages

A2. Primary balance is unchanged from 2009

A3. Permanently lower GDP growth $1 /$

\section{B. Bound tests}

B1. Real GDP growth is at historical average minus one standard deviations in 2010-2011

B2. Primary balance is at historical average minus one standard deviations in 2010-2011

B3. Combination of B1-B2 using one half standard deviation shocks

B4. One-time 30 percent real depreciation in 2010

B5. 10 percent of GDP increase in other debt-creating flows in 2010 $\begin{array}{llllllll}34 & 32 & 34 & 28 & 22 & 14 & -15 & -48\end{array}$

$\begin{array}{rrrrrrrr}34 & 9 & -6 & -24 & -42 & -59 & -136 & -270 \\ 34 & 58 & 89 & 113 & 136 & 159 & 288 & 599 \\ 34 & 36 & 42 & 41 & 40 & 37 & 56 & 216\end{array}$

$\begin{array}{rrrrrrrr}34 & 36 & 44 & 42 & 39 & 35 & 26 & 38 \\ 34 & 26 & 26 & 22 & 17 & 10 & -11 & -27 \\ 34 & 18 & 11 & 5 & -1 & -8 & -36 & -65 \\ 34 & 40 & 44 & 39 & 33 & 26 & 4 & -13 \\ 34 & 68 & 71 & 65 & 58 & 50 & 26 & 6\end{array}$

Debt Service-to-Revenue Ratio 2/

\section{Baseline}

\section{A. Alternative scenarios}

A1. Real GDP growth and primary balance are at historical averages

A2. Primary balance is unchanged from 2009

A3. Permanently lower GDP growth 1/

\section{B. Bound tests}

B1. Real GDP growth is at historical average minus one standard deviations in 2010-2011

B2. Primary balance is at historical average minus one standard deviations in 2010-2011

B3. Combination of B1-B2 using one half standard deviation shocks

B4. One-time 30 percent real depreciation in 2010

B5. 10 percent of GDP increase in other debt-creating flows in 2010

$\begin{array}{rrrrrrrr}6 & 5 & 4 & 2 & 1 & 0 & -3 & -16 \\ 6 & 5 & 6 & 7 & 7 & 8 & 13 & 41 \\ 6 & 5 & 5 & 5 & 4 & 4 & 5 & 13\end{array}$

Sources: Country authorities; and Fund staff estimates and projections

1/ Assumes that real GDP growth is at baseline minus one standard deviation divided by the square root of the length of the projection period.

2/ Revenues are defined inclusive of grants. 


\section{INTERNATIONAL MONETARY FUND}

NIGERIA

Staff Report for the 2009 Article IV Consultation--Informational Annex

Prepared by the African Department

September 24, 2009

Content

Page

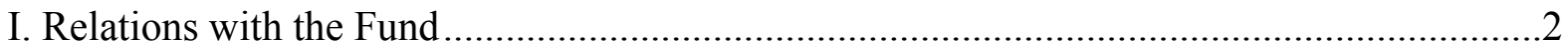

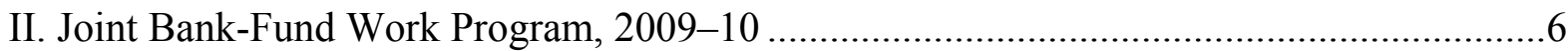

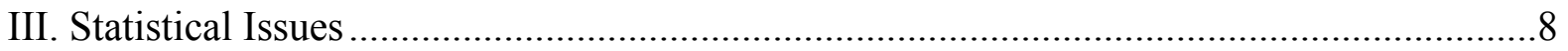




\section{Nigeria-RELATIONS WITH THE FUND}

(As of August 31, 2009)

I. Membership Status: Joined: March 30, 1961;

$\underline{\text { Article XIV }}$

II. General Resources Account:

SDR Million

\%Quota

$1,753.20$

100.00

Fund holdings of currency

$1,753.11$

100.00

Reserve Position

0.14

0.01

Holdings Exchange Rate

III. SDR Department:

SDR Million

\%Allocation

Net cumulative allocation

$1,456.82$

100.00

Holdings

$1,299.70$

89.22

IV. Outstanding Purchases and Loans: None

V. Latest Financial Arrangements:

\begin{tabular}{|c|c|c|c|c|}
\hline Type & $\begin{array}{c}\text { Date of } \\
\text { Arrangement } \\
\end{array}$ & $\begin{array}{c}\text { Expiration } \\
\text { Date }\end{array}$ & $\begin{array}{l}\text { Amount Approved } \\
\text { (SDR Million) }\end{array}$ & $\begin{array}{l}\text { Amount Drawn } \\
\text { (SDR Million) }\end{array}$ \\
\hline Stand-By & Aug 04, 2000 & Oct $3 \overline{1,2001}$ & 788.94 & 0.00 \\
\hline Stand-By & Jan 09, 1991 & Apr 08, 1992 & 319.00 & 0.00 \\
\hline Stand-By & Feb 03, 1989 & Apr 30, 1990 & 475.00 & 0.00 \\
\hline
\end{tabular}

\section{Projected Payments to Fund}

(SDR Million; based on existing use of resources and present holdings of SDRs):

Principal

\begin{tabular}{lrrrrrr}
\cline { 2 - 3 } & $\underline{2009}$ & $\underline{2010}$ & $\underline{2011}$ & $\underline{2012}$ & $\underline{2013}$ \\
Principal & 0.28 & & 0.53 & 0.53 & 0.53 & 0.53 \\
Charges/Interest & 0.28 & 0.53 & 0.53 & 0.53 & 0.53 \\
Total & & & & & &
\end{tabular}

Forthcoming

\section{Exchange Rate Arrangement}

The de jure exchange rate arrangement is floating. The Central Bank of Nigeria (CBN) sells foreign exchange to banks and exchange bureaus through twice-weekly wholesale Dutch auctions (WDAS) and intervenes periodically in the interbank market. The naira also continues to be traded in two markets for cash transactions - the bureau de change market and a small curb market. As a result of the stability of the naira against the US dollar, the de facto exchange rate arrangement was classified as stabilized from April 2008 to December 2008. The naira depreciated by 25 percent against the US dollar from December 2008 to January 2009, after which the CBN introduced a number of temporary exchange restrictions 
in an attempt to limit pressure on the naira and safeguard foreign reserves. In January 2009, the WDAS was replaced with a retail Dutch auction system (RDAS), under which: (i) bids need to be accompanied by supporting documentation to prove that the funds are for eligible transactions; and (ii) funds purchased through the auction are ineligible for trading in the interbank market. In February 2009, the CBN announced its commitment to manage the exchange rate within a band of $+/-3$ percent around the official rate recorded at that date (N145.85 to US dollar). Exchange restrictions were progressively eased beginning in May 2009 , culminating in the restoration of the WDAS on July 13, after which the naira depreciated by over 2 percent through mid-August 2009. Therefore, the exchange rate arrangement has been reclassified from a stabilized arrangement to other managed arrangement, effective January 1, 2009. Multiple prices are a technical characteristic of a Dutch Auction system and give rise to a multiple currency practice. A comprehensive assessment by MCM and LEG is needed to identify the extent of remaining restrictions and multiple currency practices.

\section{Safeguards Assessment}

Under the Fund's safeguards assessment policy, the Central Bank of Nigeria (CBN) was subject to a full safeguards assessment with respect to the Stand-By Arrangement, which expired on October 31, 2001. The assessment, which included an on-site visit, was completed on November 28, 2001. The assessment concluded that vulnerabilities existed in the areas of financial reporting and legal structure of the Central Bank.

\section{Article IV Consultation}

Nigeria is on the standard 12-month Article IV consultation cycle. The previous Article IV consultation was concluded on February 13, 2008.

\section{Technical Assistance (TA) Since 2002:}

\section{Department Purpose of TA mission}

$\begin{array}{ll}\text { MAE } & \text { FSAP } \\ \text { FAD } & \text { Public expenditure management } \\ \text { STA } & \text { Government finance statistics } \\ \text { FAD } & \text { Resident budget advisor } \\ \text { MFD } & \text { Domestic debt management } \\ \text { STA } & \text { General data dissemination standards } \\ \text { STA } & \text { National accounts } \\ \text { FAD } & \text { Budget process reforms } \\ \text { FAD } & \text { Pension reform } \\ \text { FAD } & \text { Public expenditure management advisor } \\ \text { MFD } & \text { Domestic debt management }\end{array}$

\section{Duration}

February 4-20, 2002

January 29-February 8, 2002

February 28-March 13, 20

April 19 2002-June, 2003

February 25-March 5, 2003

July 2-15, 2003

July 24-August 12, 2003

August 20-29, 2003

October 20-29, 2003

February-August 2004

February 5-17, 2004 


\begin{tabular}{|c|c|c|}
\hline LEG & FIU creation and organization & May 31-June 04, 2004 \\
\hline LEG & Legislative drafting/FIU & July $12-16,2004$ \\
\hline FAD & Tax administration & July 19-August 3, 2004 \\
\hline MFD & Monetary operations/foreign exchange & August 26-September 10, 2004 \\
\hline FAD & Public expenditure management advisor & October 2004-June 2005 \\
\hline LEG & Exchange rates systems & November 16-22, 2004 \\
\hline MFD & Bank supervision/restructuring & November 16-29, 2004 \\
\hline STA & Balance of payment statistics & February 2-16, 2005 \\
\hline FAD & Tax administration & February 8-21, 2005 \\
\hline MFD & Banking supervision, financial, exchange & \\
\hline & Market, and currency reforms & March 9-24, 2005 \\
\hline MFD & $\begin{array}{l}\text { Banking consolidation and supervision, } \\
\text { Currency reforms }\end{array}$ & August 29-September 13, 2005 \\
\hline FAD & Tax administration peripatetic advisor & July-December, 2005 (3 visits) \\
\hline FAD & Public expenditure management advisor & October 2005-April 2006 \\
\hline MFD & Banking consolidation, monetary policy & November 9-22, 2005 \\
\hline MFD & Monetary operations advisor & December $11-17,2005$ \\
\hline STA & Money and banking statistics & January 26-February 8, 2006 \\
\hline MFD & Exchange rate management advisor & February 13-20, 2006 \\
\hline MFD & Banking consolidation, monetary policy & February 27-March 10, 2006 \\
\hline STA & Balance of payment statistics & March 15-28, 2006 \\
\hline $\mathrm{MCM}$ & Monetary policy peripatetic advisor & $\begin{array}{l}\text { Since May } 20064 \text { visits (some joint } \\
\text { with HQ staff) }\end{array}$ \\
\hline MCM & Financial sector development & November 17-24, 2006 \\
\hline FAD & Tax Administration & December 6-18, 2006 \\
\hline $\mathrm{MCM}$ & Monetary policy long-term advisor & December 2006- \\
\hline MCM & Central bank accounting & February-September, 2007 (3 visits) \\
\hline FAD & Public financial management & February 14-23, 2007 \\
\hline STA & Monetary statistics & February 20-27, 2007 \\
\hline FAD & Public financial management advisor & June 2007-June 2008 \\
\hline $\mathrm{MCM}$ & Financial sector strategy & June $17-22,2007$ \\
\hline STA & National accounts (GDDS 2 project) & June 11-July 6, 2007 \\
\hline MCM & Baseline analysis of the financial sector & September 26-October 10, 2007 \\
\hline STA & Balance of payments (GDDS 2 project) & October $2-12,2007$ \\
\hline STA & Balance of payments and IIP & October 17-November 2, 2007 \\
\hline STA & National accounts (GDDS 2 project) & October 29-November 16, 2007 \\
\hline FAD & Tax policy & December 4-18, 2007 \\
\hline MCM & Banking supervision advisor & January 2008 \\
\hline FAD & Public private partnerships & February 28-March 13, 2008 \\
\hline STA & Balance of payments and IIP & June $11-24,2008$ \\
\hline STA & National accounts (GDDS 2 project) & June 23-July 4, 2008 \\
\hline FAD & $\begin{array}{l}\text { Public financial management peripatetic } \\
\text { advisor }\end{array}$ & $\begin{array}{l}\text { September 2008-June } 2009 \\
\text { (3 visits) }\end{array}$ \\
\hline
\end{tabular}




$\begin{array}{lll}\text { MCM } & \text { Inflation targeting } & \text { September 4-18, 2008 } \\ \text { STA } & \text { Balance of payments (GDDS 2 project) } & \text { September 15-October 3, 2008 } \\ \text { FAD } & \text { Public financial management } & \text { October 21-November 3, 2008 } \\ \text { STA } & \text { Monetary and financial statistics } & \text { November 5-19, 2008 } \\ \text { STA } & \text { National accounts (GDDS 2 project) } & \text { January 26-February 9, 2009 } \\ \text { STA } & \text { Balance of payments (GDDS 2 project) } & \text { April 20-May 5, 2009 } \\ \text { STA } & \text { Balance of payments and IIP } & \text { June 23-25, 2009 } \\ \text { MCM } & \text { Financial stability } & \text { July 9-23, 2009 }\end{array}$

XI. Resident Representative:

Mr. David Nellor has been the Senior Resident Representative in Abuja since April 2009. 


\section{Nigeria-JoInt World BANK-IMF Work PrograM, 2009-10}

The IMF and World Bank staffs maintain a close collaborative relationship on their work on Nigeria. The Bank staff participates in IMF consultation missions and staff visits. The Bank's work and support to the government in key structural reform areas informs Fund surveillance. The Bank and the IMF staff collaborate on the Debt Sustainability Analysis (DSA) and the Financial Sector Assessment Program (FSAP), and on actions related to Public Financial Management (PFM) reform and customs reform.

\begin{tabular}{|c|c|c|c|}
\hline Title & Products & $\begin{array}{l}\text { Provisional timing of } \\
\text { missions (if relevant) }\end{array}$ & Expected delivery date \\
\hline \multicolumn{4}{|c|}{ A. Mutual Information on Relevant Work Programs } \\
\hline \multirow[t]{6}{*}{$\begin{array}{l}\text { Bank work } \\
\text { program in } \\
\text { next } \\
12 \text { months }\end{array}$} & $\begin{array}{l}\text { Country Partnership Strategy: a } \\
\text { joint three-year multi-donor } \\
\text { partnership focuses on three } \\
\text { themes: (i) improving governance; } \\
\text { (ii) maintaining employment- } \\
\text { oriented non-oil growth; and } \\
\text { (iii) promoting human development. }\end{array}$ & & Board: July 2009 \\
\hline & $\begin{array}{l}\text { Development Policy Credit } \\
\text { (federal) to support financial sector } \\
\text { development and public financial } \\
\text { management. }\end{array}$ & & Board: July 2009 \\
\hline & Updated poverty assessment & & \\
\hline & $\begin{array}{l}\text { Public Expenditure Reviews (state } \\
\text { level) }\end{array}$ & & \\
\hline & $\begin{array}{l}\text { Public Expenditure and Financial } \\
\text { Accountability assessments (state } \\
\text { level) }\end{array}$ & & \\
\hline & $\begin{array}{l}\text { Development Policy Credit (state, } \\
\text { probably Lagos) }\end{array}$ & & \\
\hline \multirow{7}{*}{$\begin{array}{l}\text { IMF work } \\
\text { program in } \\
\text { next } \\
12 \text { months }\end{array}$} & Article IV Consultation & July 2009 & Board: October 2009 \\
\hline & $\begin{array}{l}\text { Technical assistance in the } \\
\text { following areas: }\end{array}$ & & \\
\hline & (i) Fiscal issues & & \\
\hline & Customs reform & October 2009 & October 2009 \\
\hline & Fiscal Regime for Oil and Gas & October 2009 & October 2009 \\
\hline & Fiscal accounting & Peripatetic advisor & until 2010 \\
\hline & $\begin{array}{l}\text { Public financial management } \\
\text { diagnostic mission }\end{array}$ & Tbd & \\
\hline
\end{tabular}




\begin{tabular}{|c|c|c|c|}
\hline Title & Products & $\begin{array}{l}\text { Provisional timing of } \\
\text { missions (if relevant) }\end{array}$ & Expected delivery date \\
\hline & $\begin{array}{l}\text { ROSC (incl. natural resource } \\
\text { management) }\end{array}$ & Tbd & \\
\hline & (ii) Monetary and financial issues & & \\
\hline & Banking supervision & Long-term expert & until 2010 \\
\hline & Monetary operations & Long-term expert & until 2010 \\
\hline & Central bank accounting & Tbd & \\
\hline & $\begin{array}{l}\text { Financial stability analysis (stress } \\
\text { testing) }\end{array}$ & Tbd & \\
\hline & Foreign exchange market & Tbd & \\
\hline & $\begin{array}{l}\text { Inflation targeting (macro } \\
\text { modeling) }\end{array}$ & Tbd & \\
\hline & (iii) Statistics & & \\
\hline & National accounts & Tbd & \\
\hline & BOP/IIP & Tbd & \\
\hline \multicolumn{4}{|c|}{ B. Request for Work Program Inputs } \\
\hline $\begin{array}{l}\text { Fund request } \\
\text { to Bank (with } \\
\text { summary } \\
\text { justification) }\end{array}$ & $\begin{array}{l}\text { Summary of Bank analysis and } \\
\text { support for public financial } \\
\text { management reforms in state and } \\
\text { local governments }\end{array}$ & & $\begin{array}{l}\text { Results incorporated in } \\
\text { Fund } 2009 \text { Article IV } \\
\text { staff report (Board: } \\
\text { October 2009) }\end{array}$ \\
\hline \multirow{2}{*}{$\begin{array}{l}\text { Bank request } \\
\text { to Fund (with } \\
\text { summary } \\
\text { justification) }\end{array}$} & $\begin{array}{l}\text { Assessment letter for Development } \\
\text { Policy Operation }\end{array}$ & & July 2009 \\
\hline & $\begin{array}{l}\text { Regular update of Fund } \\
\text { macroeconomic projections }\end{array}$ & & Ongoing \\
\hline \multicolumn{4}{|c|}{ C. Agreement on Joint Products and Missions } \\
\hline \multirow{2}{*}{$\begin{array}{l}\text { Joint products } \\
\text { in next } 12 \\
\text { months }\end{array}$} & DSA & no dedicated mission & Board: October 2009 \\
\hline & FSAP Update & Tbd & \\
\hline
\end{tabular}




\begin{tabular}{|c|}
\hline Nigeria-STATISTICAL ISSUES APPENDIX \\
As of August 2009 \\
\hline I. Assessment of Data Adequacy for Surveillance \\
\hline
\end{tabular}

General: Macroeconomic data are broadly adequate for surveillance; however serious data deficiencies-in particular a lack of high frequency data on economic activity, inadequate information on subnational public finances, and large errors and omissions in the balance of payments - continue to hamper policy design and monitoring. The Statistics Act passed in 2007, which established the National Bureau of Statistics as the main coordinating agency for data management, has led to a number of improvements, including better information sharing between data producing and collecting agencies. Nevertheless, a number of problems continue to prevent the compilation of timely and internally consistent data, in particular lack of good source data, and insufficient computerization.

National accounts: Statistical methods used to derive production-based GDP have been improved through the development of more comprehensive estimates for a number of individual industries, although a number of statistical challenges remain. As reported in IMF Country Report No. 8/64, revisions to the national accounts published in late-2007 led to some apparent discontinuities in the series for non-oil GDP, and in particular agricultural output in 2002 and 2004, which complicates analysis of historical economic activity. Work is ongoing to conduct a new agricultural census, which should lead to improvements in the measurement of agricultural production - a key sector accounting for over half non-oil GDP-which is currently estimated on the basis of outdated survey information. The reliance on the consumer price index to construct the constant price GDP series leads to weaknesses. The introduction of additional indices, such as a producer price index, would facilitate more accurate estimation of the constant price measure. The base year for the national accounts (1990) is in urgent need of updating given the significant chances to the structure of the economy since then. The compilation of GDP using the expenditure approach would facilitate analysis of savings-investment balances. A lack of good quality high-frequency data on economic activity makes it difficult to assess current and recent economic performance.

Prices statistics: The official monthly consumer price index (CPI), a composite of urban and rural price data, is available on a timely basis. The index has been re-referenced to May 2003=100, and there are plans to use the 2003/04 National Consumer Expenditure Survey to update the 1996/97 survey-based expenditure weights.

Government finance statistics: Fiscal data are opaque and complicated not only by the federal structure but also by a multiplicity of off-budget funds. The most pressing shortcomings are related to inadequate data coverage, particularly of the subnational governments which comprise almost one-half of total government expenditure. The federal government has limited information on the subnational fiscal accounts which makes it difficult for it to play a stabilizing role by targeting a consolidated fiscal balance; efforts to address this issue have been stymied by constitutional restrictions. To facilitate the timely preparation of a consolidated set of fiscal accounts, governments at all levels need to use consistent budget classification, chart of accounts, and accounting systems. There is also a need to formalize the publication of government accounts on a monthly or quarterly basis and to report on the operations of parastatals. 
Monetary and financial statistics: There have been significant improvements in the compilation of monetary statistics. Earlier problems with the CBN accounting framework and IT issues, which had contributed to significant distortions in reported monetary data, have now been resolved. There is a need for a clearer measure of commercial banks' foreign assets and liabilities that captures both their on- and off-balance sheet exposures. The definition of the other depository corporations (ODCs) sector should also be extended beyond commercial banks to include all deposit-taking nonbank financial institutions, such as microfinance banks and primary mortgage institutions.

Financial soundness indicators: A broad range of information on the financial sector, including both core and a number of non-core financial soundness indicators, is compiled by the CBN. However, weaknesses in transparency and disclosure practices among banks undermine the reliability of this data. The requirements to move to a common year-end reporting period by the end of 2009 and adopt IFRS accounting standard from the beginning of 2010 will be key steps in enhancing the credibility of this information.

Balance of payments: There have been significant efforts to improve the compilation of Nigeria's balance of payments data in recent years. Supported by IMF technical assistance, the authorities have expanded the range and improved the quality of data sources used to compile the balance of payments statistics. The incorporation of the CBN balance of payments data into staff's presentation of the balance of payments has resulted in significant changes, with current transfers (mainly remittances) and errors and omissions significantly higher than had earlier been estimated by staff (text table).

Table: Comparison of Revised and Previous Balance of Payments, US\$ billions

\begin{tabular}{lrrrrrr}
\hline & \multicolumn{2}{c}{2006} & 2007 & \multicolumn{2}{c}{2008} \\
Current Account Balance & Previous $^{1}$ & CBN & Previous $^{1}$ & CBN & Previous $^{1}$ & CBN $^{1}$ \\
\cline { 2 - 7 }$\quad$ & 19.9 & 38.6 & 9.7 & 31.2 & 9.6 & 42.3 \\
Trade Balance & 22.0 & 28.2 & 16.8 & 25.1 & 21.0 & 35.0 \\
Income (net) & -5.5 & -6.7 & -10.5 & -11.9 & -14.8 & -12.0 \\
Transfers (net) & 3.4 & 17.1 & 3.4 & 18.0 & 3.4 & 19.3 \\
Capital and Financial Account Balance & 0.6 & -3.1 & 3.9 & 2.7 & 1.9 & -13.3 \\
Errors and Omissions & -6.6 & -21.4 & -4.1 & -24.8 & -9.8 & -27.3 \\
Overall Balance & 13.9 & 14.0 & 9.5 & 9.0 & 1.6 & 1.7 \\
\hline
\end{tabular}

1/ Previous IMF staff estimates (April 2009 WEO)

Large errors and omissions in the balance of payments complicate the assessment of external sustainability. It will be important, therefore, to further strengthen the measurement of the balance of payments and the international investment position. There is a need for improved validation of transactions reported by banks, measurement of transactions outside the banking system and the possible under invoicing of imports, and verification of estimates of the external assets and liabilities of the banking sector (which are difficult to reconcile with other sources, such as data from Bank of International Settlements reporting banks). Nigeria has recently agreed to participated in the IMF's Coordinated Direct Investment Survey, which should facilitate improvements in the measurement of the international investment position.

The authorities have not yet initiated compilation of international reserves data in line with the Data Template on International Reserves and Foreign Currency Liquidity.

External debt: Public external debt data are of good quality and available on a timely basis. The Debt Management Office (DMO) should work to extend the coverage of their database to include private sector liabilities and foreign investment in domestically issued debt securities. 


\section{Data Standards and Quality}

Participant in the General Data Dissemination System $\quad$ No Data ROSC.

(GDDS) since 2003. Metadata need updating. 


\section{NIGERIA-TABLE OF COMMON INDICATORS REQUIRED FOR SURVEILLANCE}

As of end-August 2009

\begin{tabular}{|c|c|c|c|c|c|}
\hline & $\begin{array}{l}\text { Date of latest } \\
\text { observation }\end{array}$ & $\begin{array}{l}\text { Date } \\
\text { received }\end{array}$ & $\begin{array}{c}\text { Frequency } \\
\text { of } \\
\text { Data }^{7}\end{array}$ & $\begin{array}{l}\text { Frequency } \\
\quad \text { of } \\
\text { Reporting }^{7}\end{array}$ & $\begin{array}{l}\text { Frequency of } \\
\text { Publication }^{7}\end{array}$ \\
\hline Exchange Rates & Aug 2009 & Aug 2009 & $\mathrm{D}$ & $\mathrm{D}$ & $\mathrm{D}$ \\
\hline $\begin{array}{l}\text { International Reserve Assets and Reserve Liabilities } \\
\text { of the Monetary Authorities } 1\end{array}$ & Jul 2009 & Aug 2009 & $\mathrm{M}$ & M & M \\
\hline Reserve/Base Money & Jul 2009 & Aug 2009 & M & M & M \\
\hline Broad Money & Jul 2009 & Aug 2009 & M & M & M \\
\hline Central Bank Balance Sheet & Jul 2009 & Aug 2009 & M & M & M \\
\hline Consolidated Balance Sheet of the Banking System & Jul 2009 & Aug 2009 & $\mathrm{M}$ & M & M \\
\hline Interest Rates $^{2}$ & Aug 2009 & Aug 2009 & $\mathrm{D}$ & $\mathrm{D}$ & D \\
\hline Consumer Price Index & Jul 2009 & Aug 2009 & M & M & M \\
\hline $\begin{array}{l}\text { Revenue, Expenditure, Balance and Composition of } \\
\text { Financing }{ }^{3}-\text { General Government }\end{array}$ & 2008 & July 2009 & A & A & A \\
\hline $\begin{array}{l}\text { Revenue, Expenditure, Balance and Composition of } \\
\text { Financing }{ }^{3} \text { - Central Government }\end{array}$ & July 2009 & Aug 2009 & M & M & M \\
\hline $\begin{array}{l}\text { Stocks of Central Government and Central } \\
\text { Government-Guaranteed Debt }\end{array}$ & Dec 2008 & Jul 2009 & A & A & A \\
\hline External Current Account Balance & Mar 2009 & Jul 2009 & Q & Q & A \\
\hline Exports and Imports of Goods and Services & Mar 2009 & Jul 2009 & Q & Q & A \\
\hline GDP/GNP & Mar 2009 & Jul 2009 & Q & Q & Q \\
\hline Gross External Debt & Dec 2008 & Jul 2009 & A & A & A \\
\hline International Investment Position $^{6}$ & 2007 & Oct 2008 & A & A & A \\
\hline
\end{tabular}

\footnotetext{
${ }^{1}$ Any reserve assets that are pledged or otherwise encumbered should be specified separately. Also, data should comprise short-term liabilities linked to a foreign currency but settled by other means as well as the notional values of financial derivatives to pay and to receive foreign currency, including those linked to a foreign currency but settled by other means.

${ }^{2}$ Both market-based and officially-determined, including discount rates, money market rates, rates on treasury bills, notes and bonds.

${ }^{3}$ Foreign, domestic bank, and domestic nonbank financing.

${ }^{4}$ The general government consists of the central government (budgetary funds, extra budgetary funds, and social security funds) and state and local governments.

${ }^{5}$ Including currency and maturity composition.

${ }^{6}$ Includes external gross financial asset and liability positions vis-à-vis nonresidents.

${ }^{7}$ Daily (D); weekly (W); monthly (M); quarterly (Q); annually (A); irregular (I); and not available (NA).
} 


\section{INTERNATIONAL MONETARY FUND}

EXTERNAL RELATIONS Public Information Notice DEPARTMENT

Public Information Notice (PIN) No. 09/125 FOR IMMEDIATE RELEASE

October 28, 2009
International Monetary Fund $70019^{\text {th }}$ Street, NW

Washington, D. C. 20431 USA

\section{IMF Executive Board Concludes Article IV Consultation with Nigeria}

On October 16, 2009, the Executive Board of the International Monetary Fund (IMF) concluded the Article IV consultation with Nigeria. ${ }^{1}$

\section{Background}

Reforms initiated earlier this decade have averted the boom-bust pattern that characterized previous oil price cycles and better prepared the economy to deal with the global financial crisis. Central to this success is the oil-price-based fiscal rule, which broke the link between public spending and oil prices and created a substantial cushion of oil savings. Increased confidence in economic prospects was reflected in improved growth and lower inflation. Non-oil growth averaged 9 percent from 2004 through 2008. Real incomes have risen significantly, suggesting that poverty is likely to have fallen.

The pace of economic activity has nevertheless slowed in 2009, reflecting weaker demand from the public sector and decelerating credit extension to the private sector. However, with a good harvest in prospect, agricultural production, which grew by over 6 percent in 2008, may again do well. Constrained by security issues in the Niger Delta and, more recently, by Organization of the Petroleum Exporting Countries (OPEC) production quotas, oil production has averaged about 2 million barrels a day in recent months, about 20 percent below its 2005 peak.

\footnotetext{
${ }^{1}$ Under Article IV of the IMF's Articles of Agreement, the IMF holds bilateral discussions with members, usually every year. A staff team visits the country, collects economic and financial information, and discusses with officials the country's economic developments and policies. On return to headquarters, the staff prepares a report, which forms the basis for discussion by the Executive Board. At the conclusion of the discussion, the Managing Director, as Chairman of the Board, summarizes the views of Executive Directors, and this summary is transmitted to the country's authorities. An explanation of any qualifiers used in summing up can be found here: http://www.imf.org/external/np/sec/misc/qualifiers.htm.
} 
Lower oil prices have put pressure on the fiscal and external accounts. The overall fiscal balance at the consolidated government level is set to move from a surplus of 4 percent of gross domestic product (GDP) in 2008 to a deficit of 9 percent of GDP in 2009 due to the drop in oil revenue. The non-oil deficit is expected to narrow by about 4 percentage points to 27 percent of non-oil GDP in 2009 as a modest increase in spending at the federal government level is more than offset by spending compression at other levels of government. The balance of payments has also weakened. Net private capital flows turned negative in 2008 when foreign equity investors withdrew from the Nigerian market and Nigerian banks substantially increased their foreign currency positions. Oil exports declined by about half in the first half of 2009. International reserves fell from a peak of $\$ 62$ billion in September 2008 to $\$ 43$ billion in July 2009.

The naira has depreciated in nominal terms but is little changed from pre-crisis levels in real terms. Before the global crisis, the naira appreciated sharply, reflecting high oil prices and a close link to the strong dollar. With the onset of the crisis, the naira depreciated against the dollar by 25 percent from December 2008 to January 2009 before the authorities introduced temporary measures to manage the exchange rate within a narrow band around the prevailing dollar exchange rate. A sizeable spread between the parallel market and official rates emerged, peaking at about 25 percent in early May 2009 before falling to 7 percent by July after temporary exchange restrictions were eased.

The banking system has been pressured by deteriorating asset quality. Slower economic growth, falls in equity market indices, a depreciated naira, lower oil prices, and a period of very rapid credit growth in the period before the crisis raised questions about bank asset quality. Signs of stress became evident in the interbank market where activity diminished as the crisis developed. Following special examinations, the central bank intervened in some banks by replacing management and injecting funds. It was learned that governance in some banks had been weak and legal actions are pending.

Monetary conditions have tightened and inflation has decelerated. The growth rate of monetary and credit aggregates has slowed sharply, triggered by the economic slowdown and central bank intervention in some banks. These developments have contributed to a tightening of lending. Inflation has started to moderate, declining from a peak of 15.1 percent in December 2009 to 11 percent in August 2009.

\section{Executive Board Assessment}

Executive Directors noted that reforms initiated earlier this decade have done much to soften the impact of the global financial crisis on the Nigerian economy. The substantial cushion of oil savings and foreign reserves built up when oil prices were surging, together with bank consolidation and recapitalization, has enabled policy makers to manage the crisis fallout from a position of strength. The near-term outlook is nevertheless challenging and highly dependent on developments in oil prices. Directors welcomed the authorities' commitment to a strong macroeconomic and financial policy framework that can support 
an early recovery and lay the basis for the successful implementation of Nigeria's Vision 2020 development plan.

Directors agreed that the growth outlook warrants a supportive fiscal stance, while recognizing that financing and administrative capacity constraints limit the scope for such support. They therefore welcomed the authorities' prudent approach to fiscal policy, and its focus on actions to improve budget execution and enhance public financial management as well as to increase fiscal space. Building on past success with the oilprice-based fiscal rule, fiscal policy over the medium term will need to be more consistently counter-cyclical in order to neutralize the macroeconomic impact of swings in oil prices and support private sector-led growth.

Directors emphasized that consistent implementation of a clearly articulated monetary policy framework, focused on price stability and based on the relationship between monetary aggregates and inflation, is needed to anchor inflation expectations and establish credibility. Effective communication of the framework will also be critical, and Directors welcomed the authorities' intention to do so. Directors also welcomed the plans to move forward cautiously with the adoption of an inflation-targeting framework, with due attention to the necessary institutional underpinnings for such a regime.

Directors supported the increased flexibility of the exchange rate in recent months, which will support the implementation of monetary policy focused on price stability. They noted the staff's assessment that the level of the naira is consistent with external stability.

Directors welcomed the measures taken to identify and resolve problems in bank balance sheets. While the system as a whole has significant capital, individual banks that pursued high-risk strategies and allegedly violated governance and prudential regulations during the recent period of rapid credit growth are vulnerable. Directors urged the authorities to press ahead with their efforts to address governance problems and resolve the intervened banks.

Directors observed that a robust financial stability framework will be important for the sustained development of the financial sector. They welcomed the improvements already in train, including steps to improve the credibility of information on bank balance sheets and to establish a macro prudential unit within the central bank. Directors emphasized the urgency of implementing the framework for risk-based and consolidated supervision. It will also be important to develop a clear framework for dealing with bank failures, and to strengthen cross-border supervisory arrangements in view of the rapid expansion of Nigerian banks across borders.

Directors welcomed the proposed overhaul of the framework for the oil and gas sector, noting its critical importance from a macroeconomic perspective. They supported the authorities' goals of improving governance, enhancing transparency, and creating an efficient fiscal regime that remains attractive to investors. Achieving these improvements will require further detailed quantitative analysis and careful design of transitional 
arrangements. In parallel with energy reform, Directors welcomed the authorities' emphasis on structural reforms aimed at diversifying the economy and strengthening infrastructure.

It is expected that the next Article IV consultation with Nigeria will be held on the standard 12-month cycle.

Public Information Notices (PINs) form part of the IMF's efforts to promote transparency of the IMF's views and analysis of economic developments and policies. With the consent of the country (or countries) concerned, PINs are issued after Executive Board discussions of Article IV consultations with member countries, of its surveillance of developments at the regional level, of post-program monitoring, and of ex post assessments of member countries with longer-term program engagements. PINs are also issued after Executive Board discussions of general policy matters, unless otherwise decided by the Executive Board in a particular case. 
Nigeria: Selected Economic and Financial Indicators, 2006-14

\begin{tabular}{|c|c|c|c|c|c|c|c|c|c|}
\hline & 2006 & 2007 & 2008 & $\underline{2009}$ & 2010 & 2011 & 2012 & 2013 & 2014 \\
\hline & Act. & Act. & Act. & Est. & & & Proj. & & \\
\hline National income and prices & \multicolumn{9}{|c|}{ (annual percentage change, unless otherwise specified) } \\
\hline Real GDP (at 1990 factor cost) & 6.6 & 6.4 & 6.0 & 2.9 & 5.0 & 5.2 & 5.9 & 6.2 & 6.3 \\
\hline Oil and Gas GDP & -4.5 & -4.5 & -6.2 & -4.8 & 6.0 & 5.4 & 7.3 & 6.4 & 5.4 \\
\hline Non-oil GDP & 9.4 & 9.5 & 9.0 & 4.5 & 4.8 & 5.2 & 5.7 & 6.2 & 6.5 \\
\hline Production of crude oil (million barrels per day) & 2.36 & 2.21 & 2.09 & 2.06 & 2.11 & 2.21 & 2.35 & 2.49 & 2.61 \\
\hline Nominal GDP at market prices (trillions of naira) & 18.7 & 20.9 & 24.6 & 25.2 & 30.9 & 35.6 & 41.2 & 47.6 & 54.9 \\
\hline Nominal non-oil GDP at factor cost (trillions of naira) & 11.6 & 13.1 & 15.2 & 17.8 & 20.4 & 23.3 & 26.7 & 30.8 & 35.6 \\
\hline Nominal GDP per capita (US\$) & 1,039 & 1,153 & 1,401 & 1,089 & 1,191 & 1,244 & 1,306 & 1,375 & 1,445 \\
\hline GDP deflator & 19.5 & 4.3 & 11.0 & -0.3 & 16.7 & 9.7 & 9.1 & 8.9 & 8.5 \\
\hline Non-oil GDP deflator & 18.8 & 3.5 & 6.3 & 12.3 & 9.1 & 8.6 & 8.5 & 8.5 & 8.5 \\
\hline Consumer price index (annual average) & 8.2 & 5.4 & 11.6 & 12.0 & 8.8 & 8.5 & 8.5 & 8.5 & 8.5 \\
\hline Consumer price index (end of period) & 8.5 & 6.6 & 15.1 & 9.1 & 8.5 & 8.5 & 8.5 & 8.5 & 8.5 \\
\hline Consolidated government operations & \multicolumn{9}{|c|}{ (consists of federal, state, and local governments; percent of GDP) } \\
\hline Total revenues and grants & 33.9 & 28.4 & 32.8 & 22.2 & 28.6 & 28.8 & 29.1 & 29.2 & 29.1 \\
\hline Of which: oil and gas revenue & 29.1 & 21.9 & 26.6 & 15.0 & 21.6 & 21.8 & 22.1 & 22.1 & 22.1 \\
\hline Total expenditure and net lending & 26.9 & 29.5 & 29.2 & 31.2 & 28.7 & 28.1 & 27.5 & 27.3 & 26.8 \\
\hline Overall balance (commitment basis) & 7.0 & -1.1 & 3.7 & -9.0 & -0.1 & 0.7 & 1.6 & 1.9 & 2.3 \\
\hline Non-oil primary balance (percent of non-oil GDP) & -29.5 & -30.3 & -30.8 & -27.0 & -27.0 & -26.6 & -25.9 & -25.7 & -25.1 \\
\hline Excess crude account (US $\$$ billions $)^{1}$ & 13.2 & 14.2 & 18.3 & 13.6 & 20.6 & 21.8 & 26.2 & 30.0 & 33.8 \\
\hline Money and credit & \multicolumn{9}{|c|}{ (change in percent of broad money at the beginning of the period) } \\
\hline Broad money & 53.4 & 44.2 & 57.8 & 19.3 & 24.8 & $\ldots$ & $\ldots$ & $\ldots$ & $\ldots$ \\
\hline Net foreign assets & 72.5 & 16.4 & 26.6 & -6.2 & 8.6 & $\ldots$ & $\ldots$ & $\ldots$ & $\ldots$ \\
\hline Net domestic assets & -15.7 & 27.8 & 31.1 & 25.5 & 16.2 & $\ldots$ & $\ldots$ & $\ldots$ & $\ldots$ \\
\hline Credit to consolidated government & -38.3 & -3.5 & -15.0 & 17.0 & 0.2 & $\ldots$ & $\ldots$ & $\ldots$ & $\ldots$ \\
\hline Credit to the rest of the economy & 22.6 & 54.8 & 50.2 & 11.4 & 15.2 & $\ldots$ & $\ldots$ & $\ldots$ & $\ldots$ \\
\hline Velocity & 2.9 & 2.3 & 1.7 & 1.6 & 1.5 & $\ldots$ & $\ldots$ & $\ldots$ & $\ldots$ \\
\hline Treasury bill rate (percent; end of period) & 7.4 & 8.7 & 5.4 & $\ldots$ & $\ldots$ & $\ldots$ & $\ldots$ & $\ldots$ & $\ldots$ \\
\hline External sector & \multicolumn{9}{|c|}{ (annual percentage change, unless otherwise specified) } \\
\hline Current account balance (percent of GDP) & 26.5 & 18.8 & 20.4 & 6.9 & 13.8 & 14.3 & 14.8 & 14.7 & 14.5 \\
\hline Exports, f.o.b. & 16.9 & 15.9 & 26.3 & $-39-3$ & 29.5 & 9.2 & 9.1 & 8.6 & 7.7 \\
\hline Oil and gas export volume & -2.6 & 4.2 & -7.5 & -4.9 & 2.8 & 5.1 & 7.2 & 6.1 & 5.5 \\
\hline Import, f.o.b. & -7.0 & 34.5 & 21.2 & -13.2 & -0.6 & 6.2 & 5.8 & 7.3 & 6.4 \\
\hline Terms of trade & 9.0 & 0.3 & 17.0 & -22.7 & 15.0 & 1.1 & 0.4 & 0.8 & 0.7 \\
\hline Price of Nigerian oil (US\$ per barrel) & 64.3 & 71.1 & 97.0 & 61.5 & 76.5 & 79.5 & 81.0 & 83.0 & 84.8 \\
\hline Nominal effective exchange rate (end of period) & 97.9 & 99.8 & 100.6 & $\ldots$ & $\ldots$ & $\ldots$ & $\ldots$ & $\ldots$ & $\ldots$ \\
\hline Real effective exchange rate (end of period) & 104.5 & 109.5 & 123.8 & $\ldots$ & $\ldots$ & $\ldots$ & $\ldots$ & $\ldots$ & $\ldots$ \\
\hline External debt outstanding (US\$ billions) & 3.5 & 4.0 & 4.5 & 4.9 & 5.5 & 6.1 & 6.7 & 7.2 & 7.2 \\
\hline Gross international reserves (US $\$$ billions) ${ }^{2}$ & 41.8 & 51.3 & 53.0 & 41.6 & 44.1 & 50.0 & 59.4 & 71.1 & 84.6 \\
\hline (equivalent months of imports of goods and services) & 11.7 & 12.1 & 13.8 & 10.8 & 10.7 & 11.4 & 12.7 & 14.3 & 15.9 \\
\hline
\end{tabular}

Sources: Nigerian authorities and IMF staff estimates and projections.

${ }^{1}$ Including the naira-denominated component.

${ }^{2}$ Includes $\$ 2.6$ billion in 2009 on account of the SDR allocation 


\section{Statement by the IMF Staff Representative on Nigeria}

October 16, 2009

1. This statement summarizes economic developments since the issuance of the staff report on Nigeria's Article IV consultation (www.imf.org). These developments do not alter the thrust of the staff appraisal.

2. The central bank intervened in four banks in early October based on special examinations; this is in addition to the five intervened banks listed in the staff report. The central bank provided N200 billion (about $\$ 1.3$ billion), equivalent to about 1 percent of non-oil GDP, of liquidity support in the form of loans to these banks. Bank management was replaced in all but one bank, which recently came under new ownership. Another bank, found to have insufficient capital but a healthy liquidity position, is required to recapitalize by end June 2010 .

3. The special examinations of all banks in the system have been concluded with the ten banks found to have inadequate capital accounting for 38.1 percent of bank assets. The five banks that were intervened in August 2009 account for 26.5 percentage points (lower than the preliminary estimate of 31.5 percent reported in the staff report). The central bank also announced that as of September 25, the five banks that were intervened in August 2009 have recovered over N110 billion of previously nonperforming loans (about 10 percent of their stock of non-performing loans).

4. An additional \$2 billion (1.7 percent of non-oil GDP) of oil savings will be disbursed to the three tiers of government to provide additional support to the economy and help clear outstanding debts to the banking sector. This brings extraordinary allocations from oil savings (the excess crude account) in 2009 to $\$ 5.5$ billion (compared with $\$ 3.8$ billion assumed in the staff report). If these extraordinary allocations are spent in full in 2009, the non-oil primary deficit of the consolidated government would be 1.4 percentage points wider than the -27.0 percent of non-oil GDP projected in the staff report. 


\section{Statement by Samuel Itam, Executive Director for Nigeria}

\section{October 16, 2009}

1. My Nigerian authorities appreciate the constructive dialogue with the Fund on their economic, financial and structural reform policies aimed at sustaining macroeconomic and financial stability. These policies also are expected to spur high growth necessary for poverty reduction and attainment of the MDGs. The exchange of views with the staff during the 2009 Article IV consultation discussions was candid and my authorities are grateful for the comprehensive set of papers. There is broad agreement with the thrust of the staff's analyses and recommendations.

\section{Economic developments and outlook}

2. The implementation of sound macroeconomic policies and reforms earlier this decade has left the economy better prepared to deal with the global financial and economic crisis. The pace of economic activity, like in other parts of the world, has slowed in 2009. The balance of payments position has weakened due to lower oil receipts and increased capital outflows, and as a result the exchange rate has depreciated significantly against the US dollar. Inflation has, however, declined due largely to the lower global food and fuel prices.

3. On the immediate outlook, the authorities are somewhat optimistic and project 2009 growth at around 5 percent, relative to a growth rate of about 3 percent projected by staff. The authorities' optimism is based on expected favorable weather-induced high agricultural output, expanding telecommunications services, and relatively strong contribution of the housing and mining sectors following recent substantial investment in these sectors. For the agricultural sector in particular, both the federal and the state governments have scaled up budgetary support to broaden extension services, improve the supply of high-yielding seedlings and fertilizers, and control soil erosion. In addition, the authorities' commitment to address security-related vulnerabilities in the Niger Delta, as witnessed by the recent positive responses of militants taking advantage of the government amnesty, is improving the environment for strengthening the production potential of oil and gas. Also, the continuous recovery of the global economy and related increase in commodities prices would have a positive impact on the economy.

4. Recently, the authorities proposed to allocate an additional US\$2 billion of oil savings to the three tiers of government to provide further support to the economy and help with the ongoing restructuring in the banking sector. These allocations, if spent in full, would increase overall deficit by less than half a percentage point of GDP to about 9.4 percent in 2009 . 
5. Overall, inflation is expected to fall to single digits as good harvests make food and other agricultural produce more readily available, and supply bottlenecks related to domestic fuel shortages ease in line with positive developments in the Niger Delta. In addition, fiscal prudence, underpinned by the authorities' oil-price-based fiscal rule, is expected to continue to play a significant role in achieving and sustaining macroeconomic stability even in the face of oil price swings. Decisive and swift monetary policy actions, which have been consistent with support for growth and containment of domestic inflationary pressures, would continue to be pursued. Furthermore, the banking system consolidation implemented by the authorities a few years ago, which contributed to the robustness of the banks and increased outreach in the provision of banking services, is being strengthened with the newly developed framework for risk-based and consolidated supervision.

\section{Fiscal policy}

6. The authorities are committed to improving budget execution and public financial management. The swing from overall fiscal balance of recent years to a deficit in 2009 is mainly attributed to declining oil revenues. While financing of the deficit would be challenging without external resources, it would, nevertheless, be feasible through a combination of uncollected signature bonuses, privatization proceeds, recall of some accumulated reserves the Nigerian authorities have with the African Development Bank's Nigeria Trust Fund, and domestic borrowing. The budget for 2009 is based on a conservative oil-price assumption of US $\$ 45$ per barrel. This oil-price-based fiscal rule has enabled the authorities to neutralize the macroeconomic impact of swings in oil prices. The authorities have remained committed to this practice despite political pressures to spend. In addition, the authorities are aware that weak implementation capacity is likely to limit the pace at which spending can be scaled up in 2010, even though financing constraints are expected to ease in line with the recovery of oil prices. They are also of the view that substantial scaling up of expenditures, in the face of the constrained implementation capacity, would compromise the quality of spending.

7. The authorities are making significant progress through a number of measures they have taken to increase fiscal space to help them achieve their priorities. These include:

- $\quad$ The liberalization of petroleum and kerosene prices which is expected to free up significant resources and generate fiscal space ( about 2 percent of non-oil GDP) for higher priority spending.

- The authorities' commitment to improve budget preparation to facilitate integration of medium-term sector strategies into the budget process for 2010. Also, it is expected that increased familiarity with new procurement procedures would pave the way for improved capital project selection and implementation. 
- $\quad$ Efforts underway to reform non-oil taxation policy and administration. In this regard, several measures are being taken, including appointment of a Presidential Task Force on customs to improve the efficiency and collection of customs revenue across the nation.

\section{Monetary and exchange rate policies}

8. Monetary and exchange rate policies have returned to a more normal footing. Exceptional measures taken to limit pressure on the exchange rate have been unwound. The Central Bank of Nigeria (CBN) policy framework is based on monetary targeting. There is, however, ongoing discussion to review the current framework to make it more responsive and supportive of growth and the maintenance of price stability. In this regard, the authorities consider that improved understanding of the monetary policy transmission mechanism to the rest of the economy is critical. Efforts to complete preparatory arrangements for a move to an inflation targeting regime are ongoing, with actual transition being a medium-term objective.

9. The interbank foreign exchange has been liberalized with Wholesale Dutch Auction System (wDAS) recently re-introduced to replace the Retail Dutch Auction System (rDAS). The authorities are determined to let the exchange rate continue to float and only intervene to reduce excessive volatility. They consider such flexibility necessary to help support the monetary policy objectives. In this context, the CBN would announce in advance the calendar of its operations for each week so that market expectations are formed in a manner that is conducive to the realization of the policy objectives. The authorities consider the current level of the Naira to be consistent with external and domestic stability.

10. Regarding the financial sector, the direct impact of the global financial crisis has been well contained, and there is no direct exposure to toxic assets legacy. Foreign ownership in the financial sector is very low, and reliance on foreign funding has been limited. However, the large swing in oil prices, the resulting depreciation of the Naira, and reduced confidence in domestic capital markets mounted pressures on the banking system. In this regard, the $\mathrm{CBN}$ has responded swiftly and decisively to safeguard the financial system by providing liquidity support. While there are some vulnerabilities with few banks in terms of high levels of non-performing loans, banks overall are well-capitalized, liquid and profitable. The authorities believe that the measures being taken by the CBN to enhance transparency and disclosure on the part of the banks, including a framework for risk-based and consolidated supervision, will improve assessment of potential risks and vulnerabilities in the financial system. 


\section{Structural reforms}

11. The authorities are committed to maintaining ongoing structural reforms, including improving governance, enhancing transparency, and creating an efficient fiscal regime to maintain the growth momentum and reduce poverty. As part of the overall management of oil wealth and revenue flows, the authorities are working on the necessary legislation to set up a national Sovereign Wealth Fund in the medium-term. They are aware of the role of the private sector in growing the economy, and in this regard measures to scale up the private sector role are being phased in. They have set a goal for Nigeria to become one of the world's top 20 economies by the year 2020, and to raise per capita income to at least US $\$ 4,000$. In this regard, the authorities are in the process of developing, via a participatory process, a comprehensive plan and strategies to achieve the Vision 2020 goals and to guide the government's medium-term development plans. Among others, this development plan is expected to guide the country to reduce its dependence on oil and diversify the economy to other key sectors, including modernizing agriculture and improving manufacturing infrastructure. The Vision 2020 is expected to be finalized before the end of this year.

\section{Conclusion}

12. Despite the difficult global economic and financial environment, Nigeria's economy has shown its resilience. Nigeria entered the global crisis from a position of strength. The reforms undertaken over recent years have helped the economy, with oil savings, high international reserves, and a well-capitalized banking system preventing the type of economic crises Nigeria witnessed at the end of earlier oil price cycles. The authorities are committed to continue with strong implementation of sound macroeconomic and structural reform policies embarked upon since 2005, and which contributed to robust economic performance. They, therefore, request continuous support of the Fund, other international financial institutions, and development partners in their effort to strengthen macroeconomic stability, restore high growth rates with low inflation for poverty reduction and attainment of the MDGs. 